\title{
Euskal lexikoaren historiarako: ikerketak Euskara Arkaikoan \\ Towards a history of the Basque lexicon: studies on Archaic Basque
}

\author{
Endika Blanco \\ Universidad del País Vasco/Euskal Herriko Unibertsitatea UPV/EHU
}

\begin{abstract}
The main objective of the present study is to define a methodology to work on Basque historical lexicology, an underdeveloped field in the Basque Linguistics. The purposes are, on the one hand, to consolidate the bases for future synchronic and diachronic studies, and on the other hand, to open new research procedures for the Basque lexicon. Thus, we did a synchronic analysis of the archaic Basque language, by taking a sample of eleven documents from the $15^{\text {th }}-16^{\text {th }}$ centuries, and studying, defining and gathering the way in which lexicon was formed at that time. In conclusion, we tried to characterize the lexicon of those texts, focusing on derivatives, compounds and loanwords. To this end, we rely on the few works available about Basque language lexicon (e.g. Sarasola 1997), and especially, on some works about the lexical history of other languages spoken in the surrounding areas (e.g. Barber 1976, Nevalainen 1999).

The main corpus for our analysis was the inventory of archaic Basque words, collected from Sarasola's Euskal Hiztegia. The resulting data showed us that most of the lexicon from $15^{\text {th }}$ $16^{\text {th }}$ centuries is inherited from ancient Basque language (58\%). However, if we add some words to the mentioned corpus that were not considered in Euskal Hiztegia, the number of loanwords increases (44\%), reducing the difference with the percentage of inherited ancient Basque words (55\%). By contrast, loanwords were the most common trend to create new lexicon (66\%). In fact, loanwords are more frequent than the total of derivatives (22\%) and compounds (13\%). In any case, it is obvious that Leizarraga influenced those results.
\end{abstract}

Keywords: historical lexicology, Archaic Basque, inherited lexicon, derivation, loan words, compounds.

\section{Laburpena $^{1}$}

Lan honen helburu nagusia euskarari dagokionean oso gutxi landu izan den lexikologia historikoaren gaia jorratzeko metodologia entsegu bat egitea da. Horrela, euskal lexi-

${ }^{1}$ Artikulu honek 2014ko irailean EHUko Letren Fakultatean aurkeztutako Euskal Hizkuntzalaritza eta Filologia Masterreko Azken Lana dauka oinarrian. Bioakie nire eskerrik beroena lan honetan zehar zuzendari eta laguntzaile izan ditudan Joseba Andoni Lakarra eta Céline Mounoleri; eta baita epaimahaian izan ziren irakasleei ere, egin zizkidaten iruzkin lagungarriengatik. 
koari buruzko etorkizuneko lan sinkroniko zein diakronikoetarako oinarriak sendotu eta ikerlerro berriak zabaltzea dugu jomuga. Bide horretan, Euskara Arkaikoaren lexikoaren analisi sinkroniko bat egin dugu. XV-XVI. mendeetako hamaika testutatik lagin esanguratsu bana hartuta, garai hartako euskal lexikoaren eraketarako bideak aztertu, zehaztu eta neurtu ditugu. Hau da, testuetan lekukotzen den lexiko hori ezaugarritzen saiatu gara. Batez ere, eratorpenean, konposaketan eta mailegutzan jarri da arreta. Lan hau egiteko lanabesa eta oinarria euskararen gaineko lan lexikologiko apurretatik (adib.: Sarasola 1997) eta, bereziki, inguruko hizkuntzetako lexikoaren historia lanetatik (adib.: Barber 1976, Nevalainen 1999) jaso dugu.

Analisirako corpus nagusia Sarasolaren Euskal Hiztegia-n agertzen diren Euskara Arkaikoko hitzek osatu dute. Eta, bide honetatik eskuratutako datu orokorrek erakutsi dute XV-XVI. mendeetako lexikoan euskal ondare zaharreko hitzak (\%58) direla nagusi. Aldiz, corpus nagusiko hitzei Euskal Hiztegi-tik kanpo geratutakoak gehituz gero, maileguen kopuruak (\%44) gora egiten du ondare zaharrekoekiko (\%55) aldea txikituz. Lexiko berrigintzarako bideei dagokienez, ostera, mailegaketa da erabiliena (\%66); izan ere, maileguak eratorriak (\%22) eta konposatuak (\%13) batuta (\%35) baino nabarmen gehiago dira. Guztiarekin ere, Leizarragak emaitza orokor hauetan duen eragina nabarmena da.

Hitz gakoak: lexikologia historikoa, Euskara Arkaikoa, ondare zaharreko hitzak, eratorpena mailegaketa, hitz elkarketa.

\section{Sarrera}

Lan honen helburu nagusia euskarari dagokionean oso gutxi landu izan den lexikologia historikoaren gaia jorratzeko metodologia entsegu bat egitea da. Horrela, euskal lexikoari buruzko etorkizuneko lan sinkroniko zein diakronikoetarako oinarriak sendotu eta ikerlerro berriak zabaltzea dugu jomuga. Bide horretan, Euskara Arkaikoaren lexikoaren analisi sinkroniko bat egingo dugu. Xv-Xvı. mendeko hamaika testutarik lagin esanguratsu bat hartuta, garai hartako euskal lexikoaren eraketarako bideak aztertu, zehaztu eta neurtuko dira. Hau da, testuetan lekukotzen den lexiko hori ezaugarritzen saiatuko gara. Batez ere, eratorpenean, konposaketan eta mailegutzan jarriko da arreta. Lan hau egiteko lanabesa eta oinarria euskararen gaineko lan lexikologiko apurretatik (adib.: Sarasola 1997) eta, bereziki, inguruko hizkuntzetako lexikoaren historia lanetatik (Barber 1976, Nevalainen 1999) jaso dugu.

Beraz, ikerlan honetan, lehenik eta behin, oinarria osatzeko erabili ditugun lanak zein izan diren azalduko dugu (2.). Behin hau argituta, analisiko corpusaren eta metodologiaren berri emango dugu. Bertan, alde batetik corpusaren izaera (3.1.1.) eta osaketa (3.1.2.) erakutsiko ditugu eta, bestetik, datuak aztertzeko baliatutako metodologia edo emandako urratsak (3.2.). Ondoren, lanaren zatirik mardulenera igaroko gara, hots, analisira. Atal hau bitan bereiziko dugu. Lehenengoan (4.1.) datuen analisia eta azalpena plazaratuko ditugu eta, bigarrenean (4.2.) analisian zehar ateratako emaitzak autoreka edo testuz testu bildu eta erakutsiko ditugu. Beraz, lehenengo atalari ekiteko, batetik, gure lagineko hitzen analisitik ateratako emaitza orokorrak aztertuko ditugu (4.1.1.), gero, hitzen lehenengo lekukotasunen nondik-norakoak aurkeztuko dira (4.1.2.), eta, azkenik, hitz mota bakoitzeko emaitzak analizatuko; alegia, euskal ondare zaharreko bakunak (4.1.3.1.), eratorriak (4.1.3.2.), konposa- 
tuak (4.1.3.3.) eta maileguak (4.1.4.) hartuko ditugu hizpide. Maileguei dagokienez, beren eremu semantikoa ere aztertuko da (4.1.4.1.). Eta zati honetako azken azpiatalean (4.1.5.), azterketa osoan zehar oinarri izango dugun Sarasolaren Euskal Hiztegi-tik kanpo gelditutako hitzak behatuko ditugu. Analisiaren bigarren zati nagusian (4.2.), ikerlan honetako emaitzak erakutsiko ditugu, arreta testuetariko bakoitzean jarriz, arkaikoenetik hasi eta berrienera. Bukatzeko, datuen analisitik ateratako ondorio nabarmenenak azalduko dira (5.) eta, bide batez, ikerlanean zehar izandako arazo metodologikoen inguruan hausnartu eta, etorkizuneko zenbait ikerlerro berri aurreratuko ditugu.

\section{Oinarriak}

Euskararen historiaren ikerketan aurrerapauso handiak egin dira, batez ere, Mitxelenaren garaiaz geroztik. Baina, bestelako alderdietan (fonologian eta morfologian) nabarmenki ikusten den aurrerapena ez da lexikoaren alorrean horrenbeste islatzen. Izan ere, lexikoaren ikerketa diakroniko oso gutxi egin da. Eta, lexikoa diakronikoki aztertu ahal izateko beharrezkoak diren garai jakinetako euskararen gaineko ikerlan sinkronikoak ere urriak dira.

Egin diren lan lexikologiko gehientsuenak autore jakin baten obrara mugatutako lexikoiak izan dira. Besteak beste, Axular (Villasante 1973), Garibai (Zubiaur \& Arzamendi 1976), Etxepare (Altuna 1979), Refranes y Sentencias (Soto \& Mitxelena 1978-1979; Lakarra 1996a), Zalgize (Arzamendi \& Azkarate 1983), eta Oihenarten (Orpustan 1992) lanen hiztegiak ondu dira. Baina, analisi gutxiko lan deskriptibo mugatuak dira. Honezaz gain, bada ezinbestean aipatu beharreko alimaleko lan bikain bat, alegia, Xv-xx. mendeak bitarteko hirurehundik gora euskal testutako lexikoa jasotzen duen Orotariko Euskal Hiztegia (OEH) (Mitxelena \& Sarasola 1987-2005). Edozelan ere, bertan bildutako lexiko hori guztia aztertzeko dago oraindik. Hauekin batera, Sarasolaren tesia (1980) eta lana (1997) zein Lakarraren tesina (1984) ezin utz daitezke aipatu gabe. Euskal lexikoia, autore jakin baten hiztegiaz harago, begirada zabalago batekin aztertzen lehenetarikoak izan ziren: XV-XVI. mendeak besarkatzen ditu Sarasolaren tesiak eta, 1700-1745 bitarteko Hegoaldeko testuak ditu aztergai Lakarraren tesinak.

Euskal lexikoa nolabaiteko ikuspuntu diakroniko batetik aztertzen duten lan ezagun bakarrak Zawiszewski (2001) eta bereziki Etchebarne-ren (2006) lanak dira. Lan hauek oso jomuga ezberdinak dituzte. Izan ere, Zawiszewskik bizkaieraren oinarrizko hiztegiko maileguak aztertzea du helburu nagusi eta, aldiz, Etchebarnek jatorri latindar-erromanikodun lexikoaren mailegaketa euskaran neurtzea du jomuga. Baina, biek ala biek garai ezberdinetako lexikoa jaso, aztertu eta erlazionatzen dute, ikuspuntu historikoa oinarri betiere. Hau horrela, oso ikerlan interesgarriak dira, bai darabilten lan metodologiatik ikasteko eta baita eskuratutako emaitzak behatzeko ere.

Beste alde batetik, lexikologiarekin lotura estua duten lan lexikografikoak aintzat hartu behar dira, oso ohikoa baita hiztegiak aztertzerako garaian delako autorearen iturriak bilatzeko testu zaharretara jo eta, bertako lexikoa behatu zein aztertzea. Beraz, besteak beste, Mitxelena (1958, 1961, 1964, 1970), Sarasola (1986), Lakarra (1993, 1996b, 2010) eta Urgellen $(1997,2000,2002)$ lanak lexikologiarako ere lagungarriak izan daitezke. 
Azkenik, Europan zehar egindako lan lexikologiko historikoen gako nagusiak hartu eta euskararen ikerketara ekarri beharra dugu. Hain zuzen, inguruko hizkuntza batzuetan lan ugari egin da, ikuspegi diakronikoa oinarri, lexikoaren historia osoak burutzeraino. Honen guztiaren erakusle dira, esaterako, hizkuntzaren historia zein lexikoarena oso aurreratuak dituzten ingelesa (Görlach 1991, Barber 1997, Nevalainen 1999...), gaztelania (Dworkin 2012...) edota frantsesaren (Quemada 1967 eta ondokoak) gaineko obrak. Lan hauetan, batez ere ingelesari dagozkionetan, aurkitu dugu bai ikerlan xume hau zein etorkizuneko lan lexikologiko sakonagoak burutzeko oinarria; besteak beste, lan metodologiak, ikerbideak eta arazoen irtenbideak. Beraz, euskarako zein inguruko hizkuntzetako lanetatik lanabes multzo zabal hau hartuta, gure ikerlan honen helburua XV-XVI. mendeko testuetako hiztegia aztertu eta ezaugarritzea da; eta horrela, euskal lexikoaren historiarako oinarria apur bat sendotzea.

\section{Analisiaren oinarriak: corpusa eta metodologia}

Euskararen gaineko lan lexikologiko apurrak oinarri, eta, lexikoaren historia oso garatuta duten hizkuntzetako (batez ere ingeleseko) lanak eredu hartuta, Euskara Arkaikoaren lexikoaren analisi sinkroniko bat egin dugu. Edozelan ere, azterketa honetan zehar ateratako emaitzak beste batzuen ikerlanetakoekin alderatu ditugu, eta baita euskal lexikoaren bilakaeraren inguruko oinarri argirik gabeko baieztapen zenbait zalantzan ipini ere. Gainera, corpusaren inguruko hurrengo atalean zehar hipotesi edo uste txiki ugari plazaratuko dira, testuetako lexikoaren nolakotasunean eragin dezaketen faktoreen inguruan bereziki.

\subsection{Corpusa}

Ikerlan honen helburua euskal lexikologia historikoan dauden hutsune nabarmenak betetzen laguntzea delarik, horri ekiteko, egokiena lekukotzen diren lehenengo euskal testu zabaletarik abiatzea dela iruditzen zaigu. Gauza jakina da lexiko kopuru esanguratsua duten lehenengo euskal testuak Xv. eta, batez ere, xvI. mendeaz geroztikoak direla. Beraz, Lakarrak (1997: 511-517) euskararen periodizazioaren inguruan egindako proposamenari jarraituz, Euskara Arkaikoaren garaia izango dugu ikergai, hau da, 1600 artekoa.

\subsubsection{Corpusaren izaera}

Lan honetako corpusa, bada, Euskara Arkaikoko testuetan oinarritzen denez gero, beharrezkoa da lehenik eta behin garai hartako euskal testugintzaren izaeraren nondik-norako behinenak azaltzea. Eta are beharrezkoago, idazki hauen izaera bereziki berezia izanik. Izan ere, Euskara Arkaikoko corpusaren izaera berantiarra, tamainaz txikia, geografikoki asimetrikoa, eta kolore urrikoa dela esan daiteke. Hau da, testu asko ez izateaz gainera, batetik, lehenengo euskal testuak xv. mendekoak dira, berantiarrak beraz; bestetik, sarri falta dira zenbait dialektotako idazkiak (edo idazki luzeak); eta, azkenik, lekukotzen diren testuetan aniztasun tematiko eskasa dago. Mendebaldeko euskara (Bizkaikoa eta Arabakoa), Lapurdikoa eta Nafarroa Beherekoa nahiko ondo lekukotzen diren bitartean, Erdialdean (Gipuzkoa eta Nafarroa 
Garaian) eta Ekialde muturrean oso testu gutxi dago. Hala ere, aipatutako gabezia horiek (berankortasunari dagokiona bereziki) neurri batean behintzat gutxitu egin dira ikerlan honetan; hain zuzen, ahozko tradizioaren bilketa lanaren ondorioz iritsi zaizkigun testuak (baladak, errefrauak...) kasuan kasuko bilketa garaia baino tradizio zaharrago baten lekuko direnez gero, bildu ziren garaikoa baino berbakera arkaikoago baten (balizko sorrera garaiko hizkeraren) erakusletzat hartu daitezkeela uste dugu. Orobat, belaunaldiz belaunaldi transmititutako ahozko literatura jasotzen duten idazkietan gordetzen den hizkera oso arkaikoa dela adierazi izan duten hizkuntzalariak asko dira; besteak beste, Mitxelena (1960: 53), Lakarra (1996a: 4), edota Ulibarri (2013: 100). Beraz, azaldutako ideia hau aintzat hartuko duen euskal testuen kronologia bat zelanbait finkatu nahian, errefrau sorta guztiak bilketa garaia baino mende bat lehenagokotzat hartu dira. Eta, hau horrela, xvi. mendean bildutako Refranes y Sentencias obrakoak eta Zalgizerenak ez ezik, xvir. mendeko Isasti, Oihenart (atsotitzak soilik, ez neurtitzak) eta Belaren errefrauak ere euskara arkaikotzat jo eta, gure corpusean barne bildu ditugu.

Ikergai izango dugun corpusa hizpide harturik, beraz, lexiko arkaikoaren inguruko ondorio esanguratsuak lortzeko moduko lagin aztergarri bat hautatu nahi izan da. Eta horretarako, euskal idazkien lehenengo lekukotasun zabaletarik gehienak aukeratu dira, hamaika zehazki. Hona hemen hautatutako testuok eta beraien ezaugarri nagusi zenbait, errefrauen gainean aurrez azaldutakoa aintzat hartuta, zaharrenetik berrienera hurrenez hurren: ${ }^{2}$

- Refranes y Sentencias obrako errefrauak (1596 > 1496): ${ }^{3}$ egile ezezaguna duten atsotitzok Iruñean argitaratuak badira ere, Bizkaiko (Bilbo inguruko) euskara islatzen dute eta, 560 errefrau dira guztira orain ezagunak. ${ }^{4}$

- Zalgizeren errefrauak (xvir. mendearen lehen herena $>$ XVI. mendearen lehen herena): Bertrand Zalgize zaldun protestantea zuberotarra izanik ere, ez du bertako hizkera bete-betean erabiltzen. 205 errefrau ditu guztira.

- Isastiren errefrauak (1625 > 1525): 86 errefrau jasotzen dituen obra honen autore Lope Martinez Isasti apaiz historialaria Lezokoa da eta, Erdialdeko euskara (batez ere Nafarroakoa) baliatzen du.

-Zumarragaren gutuna (1537): Juan Zumarraga Mexikoko apezpikuak arrebari idatzitako gutun honek orrialde pasatxo du eta, Bizkaiko (Durangaldeko) hizkeraren berri ematen digu.

- Etxepareren Linguae Vasconum Primitiae (1545): Bordelen inprimatutako poesia bilduma honek (sarrera laburra prosan) 56 orrialde ditu guztira. Sarrasketan jaio eta Eiheralarreko erretore izandako Etxeparek Garaziko baxenafarreran idatzi zuen.

- Oihenarten Euskal atsotitzak eta neurtitzak (1657 > 1557): Maulen jaiotako Oihenart legegizona, politikaria, historialaria eta poeta zen, baina, bereziki

2 Testuak ezaugarritzeko erabilitako lanak: Mitxelena (1960, 1964); Tovar, Otte \& Mitxelena (1980); Akesolo (1982); Lakarra (1996a); Peillen (1996); Salaberri (2002); Bilbao et al. (2010).

3 Beste bide batetik (Lakarra \& Mounole 2014) RS eta Arrasateko Erreketa (1448) erkatzean bigarren hau bestea baino arkaikoagoa dela erakusten da eta, $R S$ ri ondo dagokiola XV.aren bigarren zatia ere bai.

4560 errefrau hauei Eneko Zuloagak (2011) orain gutxi aurkitutako biak gehitu behar zaizkie. 
nabarmentzekoa da bere garaiko euskal idazle gehienak ez bezala, laikoa zela. Honek jasotako 706 errefrauetako hitzak barne bildu ditugu, ez ostera, berak sortutako olerkietakoak. Bere hizkerak zuberotarra baino behe-nafarrera dirudiela esan ohi da, baina errefrauetan badira zubererazko hitz zenbait ere.

— Belaren errefrauak (1667 aurrekoak > 1567 aurrekoak): legegizona eta idazle kalbinista izandako Jakes Bela mauletarrak bildutako 64 errefrau ezagunak jaso ditugu. Honen hizkera zuberotarra da, Zalgize eta Oihenartena baino zuberotarragoa bederen.

— Leizarragaren Testamentu Berria, Kalendrera eta Abc (1571): Joanes Leizarragaren itzulpen lana da nabarmenki gure corpusaren zatirik handiena. Kalbindar bihurtutako apaiz katolikoa, Beraskoitzen jaio zen. Eta, bere obran, Bonapartek esan bezala, lapurtera zaharra oinarri, Iparraldeko euskaldun guztiek ulertuko zuten euskara kultua baliatu zuen.

- Misererea (XvI. mendearen bigarren erdialdea): Antonio Unzueta historialariak Madrilgo Biblioteka Nazionalean aurkitutako miserereak bi orrialde eskas ditu. Eta, autorea eta argitaratze data zehazki ezagutzen ez badira ere, XVI. mendeko Gipuzkoa mendebaldean (Goierri inguruan) kokatu ohi da.

- Lazarragaren Eskuizkribua (1600 inguruan: 1567-1602): Arabako Larrean jaio zen Joan Perez Lazarraga jaun eta "poeta» laikoa (Oihenartekin batera corpus honetako autore laiko bakarra). Bere eskuizkribuak 51 orri ditu guztira. Hauetarik gehienak (\%88 inguru) euskaraz idatzitakoak dira. Eta guk euskaraz idatzitako horietarik editoreek (Bilbao et al. 2010) "A» eta «B» deituriko zatiak aztertu ditugu. Prosa eta poesia uztartzen diren idazki honetan Arabako euskara islatzen da.

- Betolatzaren Doctrina Christiana (1596): Doktrina kristaua herrira zabaltzeko helburuarekin, Calahorrako Sinodoen aginduz egindako itzulpen lan xumea da Joan Perez Betolatza doktorearena. Eta, bertan, Betolatza herrikoa den autore honek Arabako euskara baliatzen du (hala ere, ezberdintasunak ditu Landuccio eta Lazarragaren hizkerarekin).

Corpuseko testuen goiko aurkezpenean ikus daitekeen bezala, hasteko, XvXVI. mendeetako testuetatik lexiko kopuru esanguratsu bat daukatenak jaso ditugu. ${ }^{5}$ Misererea eta Bela eta Zumarragaren testuak dira corpusean barne bildu ditugun txikienak eta, guztiarekin ere, hiru hauek orrialde pasatxoko luzera daukate. Bestalde, lexikoaren barne bariazioa ere aztertu ahal izateko, euskalki guztietako testuak jasotzen ahalegindu gara. XVII. mendeko errefrauak euskara arkaikotzat hartuta, hau neurri batean behintzat lortu dugun arren, Gipuzkoa eta Nafarroa Garaiko Euskara Arkaikoa islatzen duten testuen urritasuna nabaria da oraindik. Hain zuzen ere, lan honetan aztertuko ditugun Isastiren errefrauak eta Misererea dira aipatutako aldaera hauen testurik zabalenak.

Bariazio dialektalarekin batera, garai hartan euskarak euskal lurralde bakoitzean bizi zuen egoera sozialak ere eragina izan lezake testuetako lexikoaren nolakotasu-

5 Ez ditugu Landuccioren hiztegiko hitzak sartu, arazo bereziak aurkezteaz gain (cf. Urgell 2013) momentuz testuak soilik hustea erabaki dugu-eta. 
nean. Esate baterako, hizkuntzalari zenbaitek esana da XVI-XVII. mendeetan euskara gainbehera zetorrela Araban (Zuazo 2012: 16). Corpusa ikuspuntu diakroniko batetik begiratuz gero, lehenengo testuetatik ( $R S$, Zalgize) azkenengo testuetara (Lazarraga, Betolatza) ehun urte inguruko tartea izanda, posible da lexikoan denborak eragindako ezberdintasunak ere aurkitzea.

Azkenik, testuen generoaz zein tematikaz den bezainbatean, aniztasuna handia ez izan arren, desberdintasunak aurki daitezke. Batetik, baditugu prosan idatzitako testu batzuk; alegia, Leizarraga, Betolatza eta Zumarragarena. Itzulpen zurrunak dira lehenengo biak eta, eguneroko hizkeran idatzitako gutuna bestea. Lazarragak, ostera, prosa eta poesia uztartzen ditu. Bestetik, Etxepareren lana ia osorik da poesia, Bernat Leheteri eskainitako hitz lauzko gutuna salbu. Aldiz, Misererea lau bertso-lerrodun hamalau ahapaldik osatzen dute. Eta, azkenik, bost errefrau bilduma (RS, Zalgize, Isasti, Oihenart eta Belarena) ditugu: atsotitzak ez dira poesia, baina ezta prosa ere; eguneroko ahozko hizkeratik oso hurbil dauden tarteko testutzat jo daitezke.

Corpusaren gainbegiratze honekin bukatzeko, testuen tematikari so eginez, hamaikatik hiru guztiz erlijiosoak dira; Leizarragarena, Betolatzarena eta Misererea, hain zuzen ere. Errefrauek eguneroko bizitzako eremu ezberdinak dituzte hizpide. Etxepare eta Lazarragaren testuetan, aldiz, maitasun kontuak dira nagusi, baina, bestelako gaiak (erlijiozkoak, autobiografikoak, euskararen ingurukoak, isekazkoak...) ere aurki daitezke. Azaldu dugun bezala testu gehienak guztiz erlijiosoak ez badira ere, askotan aipatzen dira erlijio kontuak, ia autore guztiak elizgizonak ziren-eta. Laburbilduz, nahiz eta gure copuseko obra guztiak XV-XVI. mendeetako euskarazko testuak izan, testuen bolumena, dialektoa, garai zehatza, generoa eta tematika kontuan hartu beharreko faktoreak dira lexikoa ezaugarritzeko garaian.

\subsubsection{Corpusaren osaketa}

Jarraian, corpusaren osaketa modua azalduko dugu. Azterketa lexikologikoak zuzenean testuak oinarri hartuta ondu behar direla zinez uste dugun arren, obra handi baten lexiko osoa biltzeko denbora asko behar denez gero, eta, lan honetarako denbora muga kontuan hartuta, bilketa lan hau apur bat arintzeko bideak erabili ditugu. Batez ere, Sarasolaren Euskal Hiztegia (2007) eta autore jakinen lexikoi zenbait baliatu ditugu corpusa osatzeko. Sarasolaren aipatutako hiztegian, ikerlan honetarako hautatutako testu gehientsuenetako lexikoaren zati handi bat biltzen da. Bertan, lema edo sarrera bakoitzaren barruan, hitz bakoitzaren lehenengo lekukotasunaren data jasotzen da. Eta hiztegian, data hauetako bakoitza, oro har, obra jakin baten argitalpen urtearekin lotzen denez gero, hitz bakoitza lehenengoz zein obratan edo hiztegitan erabili den jakin dezakegu. Euskal hiztegi garaikideko hitz askoren lehenengo lekukotasunak ikergai dugun Euskara Arkaikoaren garaikoak dira, ezagutzen diren lehenengo euskal testu zabalak garai honetakoak baitira. Horrela, berba ugari bildu dugu. Eta, bestalde, gure lanerako Sarasolaren hiztegiak dituen mugak gainditzeko, erabili ditugu autore edo obra jakinen inguruan garatutako lexikoiak.

Beraz, corpusa osatzeko bidea interesgarria bezain luzea izan da. Hara hemen ibilbidea pausoz pauso. Lehenik eta behin, Sarasolaren Euskal Hiztegian hitzen lehe- 
nengo lekukotasunen data guztiak banan-banan behatu eta, data gure corpuseko testuei dagokiena duten hitzak markatu eta jaso ditugu. Horrela, Euskara Arkaikoko hitz asko jasotzea lortu dugu, baina, lehenago aipatu dugun legez, bide honek hainbat muga ditu.

Hasteko, Euskara Arkaikoa baino lehenago lekukotzen diren hitzak gehiegi ez badira ere, ${ }^{6}$ izan badira eta ikergai dugun garaian zein testutan lekukotzen diren behatu beharra izan dugu. Bigarrenik, hiztegi honen bitartez hitz bat lehenengo aldiz zein testutan erabili den jakin dezakegu, ez ostera horren ondoren zein beste testutan ageri den. Hirugarrenik, obra batzuk, $R S$ eta Betolatzaren ikasbidea esaterako, argitalpen urte berekoak izanik, Euskal Hiztegian data beraren azpian barne biltzen dira, eta, batekoak eta bestekoak diren hitzak bereizi behar, beraz. Laugarrenik, Oihenarten Euskal atsotitzak eta neurtitzak obran eta, ondorioz, Euskal Hiztegiko obraren argitalpen urtearen azpian, guk ikertu nahi ditugun atsotitzez gainera, autorearen poesiak ere biltzen dira eta, beraz, errefrauetako hitzak eta olerkietakoak bereizi behar izan ditugu. Bosgarrenik, gure corpuseko obra batzuk ez daude Euskal Hiztegia egiteko gehien erabili diren liburuen artean eta, ondorioz, ez dira berauen lehen lekukotasunak markatzen eta, beharbada ezta berauen hitzak jasotzen ere. ${ }^{7}$ Eta azkenik, Sarasolak Euskara Arkaikoko hitz asko bere hiztegitik kanpo utzi zituela uste dugu, beronen helburua ez baitzen testu zaharretako euskal hitz guztiak jasotzea, euskararen egungo premiei erantzungo zien euskal hiztegi bat egitea baizik (Sarasola 2007: 5).

Hortaz, behin Euskal Hiztegia hustuta, aipaturiko arazotxoak konpondu eta lexikoaren erabilera osoa ezagutu asmoz, obra jakinen gainean egindako lexikoietara jo dugu. Zehazki, Altunak (1979) Etxepare; Lakarrak (1981; 1996a) Betolatza eta RS; Arzamendi eta Azkaratek (1983) Zalgize; eta, Orpustanek (1992) Oihenarten lanaren gainean egindako lexikoiak erabili ditugu. Lan hauetan aurkitu dugun informazioarekin aurrez azaldutako muga gehienak gainditzea lortu dugu, baina, ez guztiak. Oraindik lexikoirik ez duten autoreen hitzak jasotzeko, askotariko bideak jarraitu ditugu. Leizarragaren inguruan badago Arestik (1973) egindako hitz zerrenda bat. Baina, bertan adierazten den gisara, idazle bilbotarren helburua ez zen lan lexikografiko bat egitea izan, baizik eta euskararen normalizazioan balizko erreforma berri baten zimenduak finkatzea. Hau dela-eta, Leizarragaren hitzak biltzeko, Arestiren zerrenda hau ez ezik OEH (Mitxelena \& Sarasola 1987-2005) ere baliatu dugu. Lazarragaren berbak biltzeko, ordea, Monumenta Linguae Vasconum EHUko ikerketa taldeak sortutako konkordantzia (Bilbao et al. 2010) izan dugu iturri. Eta gainerako lau testuetako hitzak, hau da, Isastirenak, Zumarragarenak, Belarenak zein Misererekoak, kopuruz gutxiago izanik, testuak zuzenean hustuta jaso dira.

Lexikoien eta bestelako lan hauen guztien bitartez, Sarasolak Euskal Hiztegitik kanpo utzitako hainbat hitz aurkitu eta jaso dugu. Baina, testuen hustuketa zuzena egin barik, zeharkako bide hauen bitartez testu guztietako hitzak oro aurkitzeko zailtasunaz ohartuta, analisirako corpusean Euskal Hiztegian ageri diren hitzak bakarrik bildu ditugu. Hala ere, Sarasolaren galbahea igaro ez duten hitz horiek ere behatu eta

${ }^{6}$ Asko handituko da altxor hau Julen Manterolak Euskal Hiztegi Historiko Etimologiko-rako egin duen bilketa sistematikoarekin.

${ }^{7}$ Lazarragaren eskuizkribua Euskal Hiztegia burutu ondoren aurkitu zenez gero, ezin izan ziren bertako hitzak aipatu hiztegia osatzeko kontuan hartu. 
neurtzen saiatu gara (ikus 4.1.5. atala). Horrela, testuen benetako izaera hobeto ezagutzeko aukera izan dugu. Bertan, Leizarragaren datuen azterketa berezitua egingo da, autore honek Euskara Arkaikoan eta, ondorioz, ikerlan honetan duen garrantzia handia baita.

Corpusa osatzen duten hitz guztiak Excel programa informatikoaren laguntzaz gorde dira. Programa honek datuak modu argi eta eskuragarrian eduki, eta, ondoko analisi kuantitatiboak arinago egiteko baliabideak eskaintzen ditu.

Lan lexikologikoetan ohikoa den legez (ikus Nevalainen 1999: 335), ikerlan honetan hitza terminoa adiera teknikoagoa duen lexema adierazteko erabiliko dugu. Hau da, aztertuko ditugun hitzak esanahia duten unitate lexiko txikienak izango dira, morfema gramatikalik gabeak. Beraz, oro har, corpus honetan ez da flexioaren bitartez sortutako izen edo aditz formarik bilduko, oinarri lexikalak baizik. Esate baterako, aditz forma guztiak (aditzoina, aditz partizipioa, aditz izena...) hitz bakarraren barruan bilduko ditugu. Bestalde, hitz baten adiera ezberdinak bereizita jasoko ditugu (adib.: bare1=animalia; bare2=organoa). Adiera desberdin hauek Euskal Hiztegian duten zenbaketa (edo hizkia) jarraituz bereiziko dira. Adiera bakarra duten hitzen kasuan, Euskal Hiztegiko lehenengo adiera ez direnak bakarrik markatuko dira.

\subsection{Datuak aztertzeko metodologia}

Etorkizuneko analisi diakroniko askotarikoak (lexikoez landa morfologikoak eta, agian, fonologikoak ere) egiteko baliagarri izango den analisi sinkroniko bat egitea da ikerlan honen jomuga. Beraz, lehenik eta behin, ikergai dugun garaian lekukotzen den euskal lexikoia hitzez hitz ezaugarrituko da. Alde batetik, hitzak euskal ondare zaharrekoak (bakunak, eratorriak edo konposatuak) edo maileguak diren aztertuko da. Eta behin hori zehaztuta, gehiago sakonduko dugu analisia.

Euskal ondare zaharreko bakunen kasuan, silaba kopuruan jarriko dugu arreta. Izan ere, garairik zaharrenetan erro monosilabikoa duten euskara bezalako hizkuntzetan, hitzen luzerak berauen konplexutasunaren berri eman diezaguke. Hau da, egungo hitz soil luze batzuk garai bateko mailegu, konposatu edota eratorriak izan litezke (ikus Mitxelena 1963 eta Lakarra 2009). Eratorpenari dagokionez, batetik, atzizki eta aurrizkiak izango ditugu aztergai. Eta bestetik, hizki hauek lexema berri bat sortzeko hartzen duten oinarriaren nolakotasuna behatuko dugu. Konposaketaz den bezainbatean, garai hartan erabiltzen ziren hitz elkartu motak zehaztuko dira. Eta, mailegaketari dagokionez, hitz mailegatuen jatorrizko hizkuntza identifikatzen saiatzeaz gainera, hauen eremu semantikoa ere analizatuko da.

Honez gain, ikerlan honetan egindako testuen berrantolatze kronologikoaren arabera, gure corpuseko hitzen lehenengo lekukotasun edo agerraldiak zein obrari dagozkion aztertuko dugu.

Behin Euskara Arkaikoaren lexikoa hitzez hitz ezaugarrituta, hitz mota bakoitzaren erabilera neurtuko dugu. Eta ondoren, emaitza hauen bitartez, ondorio esanguratsuenak ateratzen ahaleginduko gara, bai modu orokorrean bai autoreka. Honekin batera, analisian zehar, tokian tokiko gure ondorio hauek sendotzen saiatuko gara, konklusio hauek euskararen zein beste hizkuntzen gainean egindako ikerlanekin konparatuz, interesgarria deritzogu-eta ikerlanen arteko batetortze zein desberdintasunak aztertzeari. 


\section{Analisia}

\subsection{Datuen aukeraketa eta analisia}

Arestian azaldu dugun bezala, corpus osoa hamaika testutako hitz guztiak (Euskal Hiztegiaren galbahetik igarotakoak) bilduz osatu dugu. Analisirako lagina, ostera, lan honen denbora muga kontuan hartuta, « $\mathrm{A}$ » eta « $\mathrm{B}$ » letrez hasitako hitzetara mugatu dugu. Bi letra hauekin hasitako hitzak 1170 dira guztira, corpus osoaren (5000 inguru) \%23tik gora. Beraz, aztertuko den lagin honekin Euskara Arkaikoaren lexiko eraketaren inguruko emaitza esanguratsuak lortzea espero dugu. ${ }^{8}$ Lehenik, datu orokorrak, lehenengo lekukotasunak, euskararen ondare zaharreko hitzak (bakunak, eratorriak zein konposatuak), maileguak eta maileguon eremu semantikoa aztertuko dira. Honekin batera, Sarasolak Euskal Hiztegitik kanpo utzitako berben nolakotasunaren inguruko zertzelada batzuk ematen ahaleginduko gara. Eta bigarrenik, datu hauek autoreka (berr)aztertu eta analisi osoan zehar ateratako ondorio adierazgarrienak bilduko dira.

\subsubsection{Datu orokorrak}

Atal honen sarreran aurreratu dugun legez, corpuseko hamaika testuak Euskal Hiztegiaren galbahetik pasatu ostean 1170 hitz jaso ditugu. Hasteko, hitz hauek guztiak bi multzo nagusitan banatu ditugu: euskal ondare zaharrekoak, batetik, eta maileguak, bestetik. Ondoren, ondare zaharrekoen artean hitz bakunak, eratorriak eta konposatuak bereizi ditugu. Bestalde, guretzat etimologia iluna duten hitzak zalantzazkoak deritzenen artean kokatu ditugu. Besteak beste, aihen, algo, altzo, auzi, bare, burdina eta abar.

Datu orokorretatik ateratako emaitzei dagokienez (ikus 1. taula), hainbat ondorio nabarmendu daitezke. Hasteko, Euskara Arkaikoko testuetan erabiltzen diren hitz gehienak, hamar hitzetik ia sei (\%58), euskal ondare zaharretik sortuak direla esan daiteke. ${ }^{9}$ Izan ere, euskal ondare zaharreko bakunak \%37 dira, euskal ondare zaharrekoetatik eratorriak \%13 eta konposatuak \%8. Bestalde, maileguak hamarretik lau pasatxo (\%41) direla esan beharra dago. Gainerako zatia zalantzazkoek (\%1) osatuko lukete.

Alderaketa, baina, lexiko berrikuntzarako baliabideen artean eginez gero, mailegaketa da nabarmen erabiliena; izan ere, hitz mailegatuak (\%66) euskal ondare zaharretik sortutako eratorriak (\%22) eta konposatuak (\%13) batuta (\%35) baino gehiago dira. ${ }^{10}$ Ondare zaharreko hitz eratorriak konposaketaren bidez sortutakoak baino nabarmen gehiago direla ere azpimarratu beharra dago.

8 Hala ere, gauza jakina da «E», «I» eta «J» letrak aski ezberdinak direla lexikologikoki gainerakoetatik, hauetan mailegu gutxiago eta aditz zahar asko biltzen baita.

9 Hala ere, hitz eratorri eta konposatuetako osagaiak zenbaitetan mailegatuak dira. Ikus 4.1.3.2. eta 4.1.3.3. atalak.

10 Hemen «iruzur» edo auzi metodologiko txiki bat dago: maileguak noiznahikoak (2000 urte) jaso ditugu, baina eratorri/konposatutzat sinkronikoak bakarrik (bakunen artean hitz konplexu zahar asko). 


\section{1. taula}

Euskara Arkaikoko lexikoaren nolakotasuna

\begin{tabular}{|l|c|}
\hline \multicolumn{1}{|c|}{ Hitzak } & Kopurua \\
\hline Euskararen ondare zaharrekoak & $678(\% 58)$ \\
Bakunak & $430(\% 37)$ \\
Eratorriak & $157(\% 13)$ \\
Konposatuak & $91(\% 8)$ \\
Maileguak & $477(\% 41)$ \\
Zalantzazkoak & $15(\% 1)$ \\
\hline Guztira & 1.170 \\
\hline
\end{tabular}

Emaitza hauek hizkuntzalari zenbaitek egindako baieztapen eta lanekin konparatuz gero, askotan aldeak nahiko nabarmenak direla esan beharra dago. Izan ere, Lafittek (1979: hitzaurrea) hirutik bi edo mailegutzat zuen euskal lexikoan; Traskek (1997: 249) gutxixeago, erdia pasatxo edo euskara modernoan. Hala ere, Lakarrak (2012: 26) honen inguruan dioen legez, «eztabaida baino iritzi-trukaketa izan da euskarak omen duen mailegu kopuruari dagokionez (...) eta badirudi zifra bat edo beste aliritzian eman dutela». Hain zuzen ere, egin izan diren baieztapenek oinarri apala dutela esan daiteke, ez baitute euren kalkuluek oinarrian behar luketen corpusaren gaineko datu edo erreferentziarik ematen.

Oinarri sendoagoak dituzte, ordea, Adam Zawiszewski (2001) eta Michel Etchebarne-ren (2006) lanek. Zawiszewskik bizkaieraren oinarrizko hiztegiko maileguak aztertzea du helburu nagusi, eta, horretarako darabilen corpusa bizkaiera (arkaikoa eta egungoa) eta euskara batuko oinarrizko lexikoarekin osatzen du. Egiten dituen analisi ezberdinetan maileguen kopurua \%15,5 baino txikiagoa da beti. Etchebarneren lanari dagokionez, jatorri latindar-erromanikodun lexikoaren mailegaketa euskaran neurtzea du jomuga, eta, bere ikerlanean hiru corpus erabiltzen ditu: Euskal Atlas Etnolinguistikoa, XV-Xx. mendeetako zenbait literatur lanetako laginak eta, Euskal Atlas Linguistikoa. Corpus motaren arabera, emaitza ezberdinak lortzen ditu eta, eguneroko hizkeran (\%13-\%23) literatur obretan (\%29-\%41) baino mailegu gutxiago erabiltzen dela ondorioztatzen du. Baina, corpusa edozein delarik ere, euskararen ondare zaharreko hitzen kopurua \%64-\%87 bitartekoa omen da beti. Nahiz eta lan hauetako corpusak eta gurea guztiz alderagarriak ez izan, gure emaitzak eta Etchebarnerenak nahikoa bat datozela esan daiteke.

Euskaratik beste hizkuntzetara jauzi txiki bat egin eta, Euskara Arkaikoko gure emaitzak eta ingeleseko garai beretsukoak, alegia, Early Modern English-ekoak (1500-1700), alderatuko ditugu. Ingelesaren lexikoaren inguruan, ikerlan bi behatu ditugu, Wermser (1976, in Nevalainen 1999) eta Barber (1997), hain zuzen ere. Eta, batean eta bestean erabilitako corpusak desberdinak direnez gero, emaitzak ere ez dira zeharo berdinak. Barberrek The Oxford English Dictionary (OED) erabili zuen bitartean, Wermserrek Chronological English Dictionary (CED) baliatu zuen. Bigarren hiztegia $(C E D)$ lehenengoan $(O E D)$ oinarriturik egina dago; baina, CEDtik kanpo utzi dira sarrera buruak ez diren $O E D$ ko azpisarrera guztiak. Eta, ondorioz, $C E D$ n ez dira lexiko berrikuntzarako bide batzuk, bereziki konposaketa, egoki azaltzen. Hau 
horrela, Wermserren arabera (in Nevalainen 1999: 350), lexiko berrikuntzaren \%47 mailegatua, \%41 eratorpena edo konposaketa bidezkoa, eta \%7 bestelako prozesu xumeagoen bitartez sortutakoa da. Barberren (1997: 221) arabera, ostera, \%33 mailegatua da, \%59 eratorria (\%47) edo konposatua (\%12), eta \%7 bestelako bideetarik sortutakoa. Beraz, Wermserren ikerlanean gehiengoa mailegatua da eta, aldiz, Barberrenean eratorpenaren eta hitz elkarketaren bitartez sortutakoa. Bien arteko aldea nabarmena da, baina esan bezala, neurri batean behintzat corpus ezberdintasunaren ondorio izan daiteke. Euskara Arkaikoko gure corpusean, lexiko berrikuntzarako bideei dagokienez, mailegu kopurua (\%66) eratorrien (\%22) eta konposatuen (\%13) batura (\%35) baino nabarmen handiagoa da. Beharbada, guk corpusa osatzeko oinarri hartu dugun Euskal Hiztegia erabiltzeko moduak eragina izan dezake emaitza hauetan. Hiztegi honetako azpisarrera zenbait bildu ditugun arren, sarrera buruetan ipini baitugu bereziki arreta.

Segidan, corpusean jasotako 1170 hitz horietatik autore bakoitzak zenbat erabiltzen dituen behatuko dugu (ikus 2. taula). Azterketa hau egiterako garaian, kontuan hartu behar da, corpusaren atalean azaldu dugun legez, Euskara Arkaikoaren garaiko testuak oso tamaina ezberdinetakoak direla. Beraz, autore bakoitzak erabiltzen dituen hitz kopuruarekin batera, bakoitzaren obraren bolumenaren inguruko xehetasunak ere gogoraraziko ditugu. Leizarraga da, bere obraren tamaina aintzat hartuta aurreikusten genuen bezala, nabarmenki hitz gehien baliatzen duen autorea, 1.170 berbatatik 752 (\%64). ${ }^{11} 300$ hitz inguruan, Oihenart (314; \%27) eta Lazarraga (290; \%25) ditugu. Bataren 706 errefrau eta bestearen 52 orrialdeko lanarekin ez da harritzekoa. 200 hitz inguruan, hurrenez hurren 15 poema eta 539 errefraudun, Etxepare $(218 ; \% 19)$ eta $R S$ (194; \%17) aurki ditzakegu. Zalgizeren 205 errefrautan corpus honetako 121 (\%10) hitz ageri dira. Gainerako bost testuetan, 100 berbatik behera baliatzen dira: Isastiren 86 errefrauetan 83 (\%7), Betolatzaren doktrinan 70 (\%6), Zumarragaren orrialde pasatxodun gutunean 32 (\%3), Belaren 64 errefrauetan 30 (\%2), eta 4 lerrotako 19 ahapaldi dituen Misererean 29 (\%2). Ez dugu emaitza hauetan asaldatu gaituen daturik aurkitu. Zerbaitek apur bat harritu bagaitu, gure corpusera Lazarragak Oihenartek baino berba gutxiago ekartzea izan da. Edonola ere, horren arrazoiak, batetik, Lazarragak hitz berak agian maiz errepikatzea eta, bestetik, bere mailegu sustraitu gabe ugari Sarasolak Euskal Hiztegitik kanpo uztea izan daitezke (ikus 4.1.5 atala).

Analisia hitz motak eta autoreak gurutzatuz eginez gero (ikus 2. taula), ${ }^{12}$ euskal ondare zaharrekoei dagokienean, oro har, obra handien artean, Oihenart (\%72) eta bereziki $R S k o$ (\%78) ugaritasuna da nabarmentzekoena. Baina, Leizarraga (\%57) eta Lazarraga (\%49) kenduta, gainerako guztiek ere batazbesteko orokorretik (\%58) gora dutela esan beharra dago. Bakunetan, RSko datua da esanguratsuena, 128 (\%66) berbarekin aurre hartzen baitie, oro har aurretik dituen Etxepare (99, \%45) eta Lazarragari $(125, \% 43)$. Leizarragak bere handitasunean duen kopuru txikia ere $(275, \% 37)$ nabarmendu daiteke. Eratorrietan, Lazarragaren urritasuna $(6, \% 2)$ eta Oihenart $(34, \% 11)$ eta bereziki Leizarragaren ugaritasuna $(106, \% 14)$ dira azpimarragarrie-

\footnotetext{
${ }^{11}$ Leizarragaren obrak duen luzera kontuan hartuta, besteekiko duen aldea ez da hainbestekoa.

12 Hemendik aurrera egingo ditugun autorekako analisi guztietan datu absolutuak eman aurretik, testu bakoitzaren tamainaren araberako ondorioak ateratzen saiatuko gara. Bestela, Leizarragaren testuaren handitasunak gainerako guztien datuak itotzen ditu.
} 


\section{2. taula}

Euskara Arkaikoko lexikoaren nolakotasuna testuz testu

\begin{tabular}{|c|c|c|c|c|c|c|c|c|c|c|c|c|}
\hline & RS & $\mathrm{Zgz}$ & Is & $\mathrm{Zm}$ & Etxp & Oih & Bela & Leiz & Mis & $\mathbf{L a z}$ & Bet & Guzt. \\
\hline \multirow{2}{*}{ Euskal ondare zaharrekoak } & 152 & 80 & 55 & 26 & 128 & 225 & 21 & 431 & 17 & 142 & 44 & \multirow{2}{*}{1.321} \\
\hline & $\% 78$ & $\% 66$ & $\% 66$ & $\% 81$ & $\% 59$ & $\% 72$ & $\% 70$ & $\% 57$ & $\% 59$ & $\% 49$ & $\% 63$ & \\
\hline \multirow{2}{*}{ Bakunak } & 128 & 69 & 36 & 25 & 99 & 166 & 19 & 275 & 17 & 125 & 37 & \multirow{2}{*}{996} \\
\hline & $\% 66$ & $\% 57$ & $\% 43$ & $\% 78$ & $\% 45$ & $\% 53$ & $\% 63$ & $\% 37$ & $\% 59$ & $\% 43$ & $\% 53$ & \\
\hline \multirow{2}{*}{ Eratorriak } & 17 & 7 & 7 & 1 & 10 & 34 & 1 & 106 & \multirow{2}{*}{0} & 6 & 6 & \multirow{2}{*}{195} \\
\hline & $\% 9$ & $\% 6$ & $\% 8$ & $\% 3$ & $\% 5$ & $\% 11$ & $\% 3$ & $\% 14$ & & $\% 2$ & $\% 9$ & \\
\hline \multirow{2}{*}{ Konposatuak } & 7 & 4 & 12 & \multirow{2}{*}{0} & 19 & 25 & 1 & 50 & \multirow{2}{*}{0} & 11 & 1 & \multirow{2}{*}{130} \\
\hline & $\% 4$ & $\% 3$ & $\% 14$ & & $\% 9$ & $\% 8$ & $\% 3$ & $\% 7$ & & $\% 4$ & $\% 1$ & \\
\hline \multirow{2}{*}{ Maileguak } & 36 & 38 & 26 & 6 & 89 & 84 & 8 & 316 & 12 & 145 & 26 & \multirow{2}{*}{786} \\
\hline & $\% 19$ & $\% 31$ & $\% 31$ & $\% 19$ & $\% 41$ & $\% 27$ & $\% 27$ & $\% 42$ & $\% 41$ & $\% 50$ & $\% 37$ & \\
\hline \multirow{2}{*}{ Zalantzazkoak } & 6 & 3 & 2 & \multirow{2}{*}{0} & 1 & 5 & 1 & 5 & \multirow{2}{*}{0} & 3 & \multirow{2}{*}{0} & \multirow{2}{*}{26} \\
\hline & $\% 3$ & $\% 2$ & $\% 3$ & & $\% 0,5$ & $\% 2$ & $\% 3$ & $\% 1$ & & $\% 1$ & & \\
\hline Guztira & 194 & 121 & 83 & 32 & 218 & 314 & 30 & 752 & 29 & 290 & 70 & 2.133 \\
\hline
\end{tabular}

nak. Hemen ere RSk (17, \%9) Etxepare (10, \%5) eta Lazarraga (6, \%2) gailentzea ere aipatzeko modukoa da. Konposatuez den bezainbatean, Lazarraga, (11, \%4), RS (7, \%4) eta Zalgizeren (4, \%3) eskasiarekin batera, Isastik (12, \%14) hitz elkartu ugari (aurreko hirurak baino gehiago) dituela esan beharra dago. Maileguei dagokienean, Lazarragaren ugaritasuna $(145, \% 50)$ eta Oihenart $(84, \% 27)$ eta bereziki RSko (36, \%19) urritasuna dira nabarmen.

Beraz, autoreen arteko konparaketa honetatik ateratakoa laburbilduz:

- Leizarragak euskal ondare zaharreko hitz bakunak, (275, \%37) gainerako autoreen ehunekoekin alderatuz (\%43tik gora), urri dituela da nabarmentzekoena. Eta, ugari ditu, bereziki, eratorriak (106, \%14).

- Oihenartek euskal ondare zaharreko hitz ugari $(225, \% 72)$ eta hitz mailegatu gutxi $(84, \% 27)$ du.

- Lazarragak joera handia du mailegaketarako $(145, \% 50)$ eta txikia ondare zaharreko eratorri $(6, \% 2)$ eta konposatuak (11,\%4) erabiltzeko.

- Etxepareren hitz moten artean erabat nabarmentzeko ezer aurkitu ez arren, eratorriak $(10, \% 5)$ baino konposatu gehiago (19, \%9) baliatzea da aipagarriena.

- $R S \mathrm{n}$ ondare zaharreko hitzen $(152, \% 78)$, bereziki bakunen $(128, \% 66)$, nagusitasuna eta maileguen (36, \%19) urritasuna dira nabarmen.

- Zalgizeren errefrauetan (zein gainerako obra txiki guztietan) euskal ondare zaharreko hitzak gailentzen dira.

- Isastik duen konposatu kopurua (12, \%14) da azpimarratzekoa.

Testu hauetan, handietan gutxienez, errefrauetan (Oihenart eta $R S$ ) prosa lanetan (Leizarraga eta bereziki Lazarragarenean) baino mailegu askozaz gutxiago dagoela na- 
baria da. Beraz, goiko emaitza hauetan, testuen kronologia edo dialektoak barik, testuen generoak eragiten duela uste dugu. Izan ere, Leizarragarena itzulpena da eta, Lazarragak ere itzulitako poema zenbait ditu (ikus Gómez 2011).

Behin datu orokor hauek aztertuta, esan daiteke Leizarragaren testuaren bolumen izugarriak ${ }^{13}$ guztiz baldintzatzen dituela emaitza orokorrak (ondare zaharreko bakunak $\% 37$, eratorriak $\% 13$, konposatuak $\% 8$, maileguak $\% 41$ ), eta, ia ez duela uzten gainerako autoreek emaitza horietan eragitea. Hori erakusten dute datu orokorrekin ia bat datozen bere ehunekoek: bakunak \%37, eratorriak \%14, konposatuak \%7, maileguak \%42. Beraz, interesgarria iruditu zaigu Euskara Arkaikoaren lexikoa Leizarragarekin eta Leizarraga gabe zenbat aldatzen den behatzea (ikus 3. taula). Eta, aipatu alderaketa eginez gero, Leizarraga gabe Euskara Arkaikoak mailegu, konposatu eta bereziki eratorri gutxiago eta hitz bakun gehiago izango lituzkeela ikus daiteke.

3. taula

Euskara Arkaikoko lexikoa Leizarragarekin eta Leizarraga gabe

\begin{tabular}{|l|c|c|c|}
\hline \multicolumn{1}{|c|}{ Hitzak } & Kopurua guztira & $\begin{array}{c}\text { Kopurua Leizarraga } \\
\text { bakarrik }\end{array}$ & $\begin{array}{c}\text { Kopurua Leizarraga } \\
\text { gabe }\end{array}$ \\
\hline Euskal ondare zaharrekoak & $678(\% 58)$ & $223(\% 56)$ & $455(\% 59)$ \\
Bakunak & $430(\% 37)$ & $103(\% 26)$ & $327(\% 42)$ \\
Eratorriak & $157(\% 13)$ & $86(\% 22)$ & $71(\% 9)$ \\
Konposatuak & $91(\% 8)$ & $34(\% 9)$ & $57(\% 7)$ \\
Maileguak & $477(\% 41)$ & $174(\% 44)$ & $303(\% 39)$ \\
Zalantzazkoak & $15(\% 1)$ & $3(\% 1)$ & $12(\% 2)$ \\
\hline Guztira & 1.170 & 400 & 770 \\
\hline
\end{tabular}

\subsubsection{Lehenengo lekukotasunak}

Atal honetan gure corpuseko hitzak lehenengo aldiz zein testutan aurki daitezkeen ikusiko dugu, hau da, autore bakoitzak zenbat (eta zelako) hitzen lehenengo lekukotasun dituen behatuko da. Aurretik, baina, testuen kronologiaren inguruan lan honetarako hartutako erabakia bergogoratu beharra dugu, lehenengo lekukotasunen emaitzetan eragin handia du-eta. Arestian azaldu dugun legez, errefrauek (eta balada eta eresi zaharrek) beren bilketa garaikoa baino hizkera arkaikoagoa islatzen dutenez, bilketa urteak baino lehenagoko euskararen erakusletzat jo ditugu. Eta, hau horrela, $R S$, Zalgize, Isasti, Oihenart eta Belaren errefrauak bildu eta argitaratu urteak baino mende bat lehenagokoak bailiran baliatuko ditugu. Beraz, analisi hau ez da XvI. mendeko lehenengo lekukotasunen inguruko horrelako azterketetan (ikus Sarasola 1997: 639) ohikoa den bezala Etxeparerekin edo hasiko, errefrauekin baino.

Behin beharrezko azalpenak emanda, datuak aztertzeari ekinez gero (ikus 4. taula), Xv. mende amaierako $R S$ tik hasi eta XvI. mende amaierako Betolatzagana $(\% 27)$

13 Leizarragak corpuseko 1170 hitzetatik 752 (\%64) erabiltzen ditu; bigarrenak, Oihenartek, 314 


\section{4. taula}

Euskara Arkaikoko lehenengo lekukotasunen nolakotasuna testuz testu

\begin{tabular}{|l|r|r|r|r|r|r|r|r|r|r|r|}
\hline & RS & Zgz & Is & Zm & Etxp & Oih & Bela & Leiz & Mis & Laz & Bet \\
\hline Euskal ondare zaharrekoak & 152 & 40 & 31 & 11 & 70 & 97 & 2 & 241 & 4 & 29 & 1 \\
Bakunak & 128 & 32 & 14 & 11 & 46 & 56 & 2 & 117 & 4 & 19 & 1 \\
Eratorriak & 17 & 6 & 6 & 0 & 8 & 26 & 0 & 90 & 0 & 4 & 0 \\
Konposatuak & 7 & 2 & 11 & 0 & 16 & 15 & 0 & 34 & 0 & 6 & 0 \\
Maileguak & 36 & 35 & 20 & 4 & 72 & 42 & 1 & 203 & 4 & 58 & 2 \\
Zalantzazkoak & 6 & 2 & 0 & 0 & 0 & 2 & 0 & 3 & 0 & 2 & 0 \\
\hline 1. lekukotasunak guztira (1170) & $\mathbf{1 9 4}$ & $\mathbf{7 7}$ & $\mathbf{5 1}$ & $\mathbf{1 5}$ & $\mathbf{1 4 2}$ & $\mathbf{1 4 1}$ & $\mathbf{3}$ & $\mathbf{4 4 7}$ & $\mathbf{8}$ & $\mathbf{8 9}$ & $\mathbf{3}$ \\
\hline Hitzak guztira & 194 & 121 & 83 & 32 & 218 & 314 & 30 & 752 & 29 & 290 & 70 \\
\hline
\end{tabular}

bitarteko gure testuetako lehen agerraldien bilakaera aise antzeman daiteke. RSk, lehenengoa izateaz gainera tamaina esanguratsua izanda, dituen 194 (\%17) lehenenengo agerralditatik jaisten doa kopurua hurrengo Zalgize (77, \%7), Isasti (51, \%4), eta Zumarragaren $(15, \% 1)$ obra apalagoetan. Ondoren, Belaren $(3, \% 0,25)$ salbuespenarekin, Etxepare $(142, \% 12)$ eta Oihenarten $(141, \% 12)$ lanekin nabarmen egiten du gora berriz ere, Leizarragarekin $(447, \% 38)$ goia jo arte. Ostean, beheranzko joera nabari daiteke. Esaterako, Lazarragak corpus honetatik baliatzen dituen 290 hitzetatik 89 (\%30) bakarrik dira lehenengo lekukotasunak, lehenengo agerraldi kopuru osoaren $\% 8$, alegia.

Datu hauetatik beste hainbat ondorio ere atera daitezke. Batetik, oraintsu aipaturiko Lazarragaz gainera, Oihenart, Bela, Misererea eta Betolatza dira lehenengo agerraldien kopurua beraien hitz guztien erdia inguru izatera iristen ez direnak. Emaitza honen arrazoi nagusia bost testu hauek kronologikoki corpus osoko azken seien artean kokatzea izango da. Baina, autoreek darabilten testu motek eta, ondorioz, hitz motek ere izan dezakete emaitza hauetan zerikusi apur bat. Adibidez, Oihenarten kasuan, aurretik daukan $R S$ n bezalatsu, euskal ondare zaharreko hitzak erabiltzeko joera handiak azal ditzake aipaturiko datuak. Eta gaiak errepikatzeak, $R S$ eta Oihenart artekoa pixkat eta, Leizarraga eta Betolatza artekoa erabat.

Atal honekin bukatzeko, interesgarria izan daiteke testuen berregituratze kronologikoaren ostean lehenengo agerraldien gainean lortutako emaitzak Sarasolak (1997: 639-640) ohiko kronologiari jarraituz eskuratutakoekin alderatzea. Hala ere, Sarasolak ikerlan handi baten ostean, autore gutxi batzuren datuak soilik erakusten ditu xeheki, eta, Euskara Arkaikoari dagokionez, Etxepare eta Leizarragarenak bakarrik. Sarasolaren arabera, 362 eta 1009 dira, hurrenez hurren, Etxeparek eta Leizarragak euskararen hitz altxorrera dakartzaten lehen agerraldiak. Guk, egindako aldaketak tarteko, ostera, Etxepareren 142 eta Leizarragaren 447 bildu ditugu. Erdia baino zertxobait gutxiago bien kasuan ere. Beraz, errefrauak sortu bide ziren beren hizkerari dagokion garaikotzat hartzeak, nabarmen aldatzen du lehenengo agerraldien argazkia. Hala ere, testuen sailkatze kronologiko ezberdinaz landa, bi corpusen artean badago alde txiki bat, gurean A-B letrak aztertu diren bitartean, Sarasolak D-tik Irakoak analizatu baitzituen. Baliteke honek emaitzetan eragin apur bat izatea (ikus 
8. oin-oharra), baina guztiarekin ere, biona da hiztegi osoaren $\% 22$ (berak)- $\% 23$ (guk) inguru.

\subsubsection{Euskal ondare zaharreko hitzak}

Atal honetan euskal ondare zaharreko hitzen inguruan jardungo dugu. Eta ezer baino lehen, hitzak euskal ondare zaharreko berbatzat hartzeko kontuan edukitako irizpideak azaldu behar ditugu. Euskal ondare zaharrekotzat hartu ditugu beraien forma eta esanahiaren azalpena euskararen barnean soilik aurkitzen duten hitzak.

\subsubsection{Euskal ondare zaharreko bakunak}

Azpiatal honetan, oro har, hitz soilak soilik bildu ditugu. Baina, euskal ondare zaharreko bakunen artean sartu ditugu, jatorrian hitz konposatu edo eratorri argi samarrak izan arren, urte eta mendeen poderioz eraketa modua ilundu eta, XV-XVI. mendeetako hiztunek bakuntzat joko zituztela uste ditugun hitzak. Besteak beste, bazkari, afari, bekaitz eta aratuste. Gainerako hitz konplexuak (eratorri zein konposatuak), nahiz eta oinarrian euskal ondare zaharretik etorri, bereizita sailkatu ditugu, lexiko berrikuntzarako bideak aztertu ahal izateko.

Ikerlan honek hitzen forma ezberdinak barik oinarri lexikalak aztertzeko helburua izan arren, flexiodun hitz zenbait ere jaso ditugu. Alegia, postposizioren bat izanda ere lexikalizatutako berbatzat hartu ditugunak; esate baterako, aurkaz, azkenik eta buruko. Sarasolaren hiztegian sarrera buru dira gainera hitz hauek guztiak. Aditzen artean, auzia korapilatsuagoa da agian, baina, arestian azaldu dugun legez, gure oraingo helburua lexemak aztertzea denez gero, aditz forma guztiak forma bakarraren barruan biltzea erabaki dugu. Zehazki, partizipioaren barruan kokatu ditugu guztiak. Hauen artean, $-i$ eta $-t u$ partizipiodunak aurki daitezke. Batarekin zein bestearekin eratutako hitzak euskal ondare zaharreko bakunen barruan kokatu ditugu, atzizki hauek XV-Xvi. mendeetarako deribazio ahalmena galdua zutela uste baita. Hau da, aztergai dugun garairako atzizki hauek flexio izaera zutela uste dugu. Aditz lokuzioak ere aditz konposatutzat baino aditz esapidetzat jo ohi dituztenez (ikus Azkarate 1990: 407-415), egokiena hemen barne biltzea iruditu zaigu.

Bestalde, analisiari dagokionez, euskal ondare zaharreko hitz bakun guztiak silaba kopuruaren arabera sailkatu ditugu. Sailkapen hau azalean singlea bada ere, muinean euskararen forma kanonikoaren bilakabidearen inguruko zantzuak isla ditzake. Lakarrak 1995az geroztikako ikerlanetan erakutsi duenez, badirudi protoeuskaran monosilabikoa zen erroa beranduago (Erdi Aro inguruan beharbada) bisilabikoa izatera igaro zela. Aldaketa hori, baina, hainbat faktoreren eraginez (metatesiak, neutralizazioak, asimilazioak, berranalisiak...) gertatu zen (ikus Lakarra 2009: 579-581). Beraz, hitzen luzerak berauen konplexutasunaren berri eman diezaguke batzuetan. Eta, orain soiltzat ditugun berba zenbait lehenagoko eratorri edo konposatuak (edo maileguak) izan daitezke.

Sailkatze irizpideak eta oinarriak behin azalduta, emaitzak aztertzeari ekinez (ikus 5. taula), hasteko, euskal ondare zaharreko hitz bakunak 430 direla ekarri behar dugu gogora. Beste alde batetik, hamar hitzetik zortzi baino gehiago bi (\%46) edo hiru silabakoak (\%38) direla nabarmendu beharra dago. Monosilabikoak zein bost silaba- 


\section{5. taula}

Euskara Arkaikoko ondare zaharreko hitz bakunen nolakotasuna

\begin{tabular}{|l|c|}
\hline \multicolumn{1}{|c|}{ Ondare zaharreko bakunak } & Kopurua \\
\hline Monosilabikoak & $11(\% 3)$ \\
Bi silabakoak & $197(\% 46)$ \\
Hiru silabakoak & $163(\% 38)$ \\
Lau silabakoak & $51(\% 12)$ \\
Bost silabakoak & $8(\% 2)$ \\
\hline Guztira & 430 \\
\hline
\end{tabular}

koak, ordea, oso gutxi dira, eta ez dute bien artean hitz guztien $\% 5$ ere osatzen. Lau silabakoak hamarretik bat pasatxo dira. Beraz, bi silabakoak dira gehienak eta, hitz monosilabiko bakoitzeko bi silabako hemezortzi jaso ditugu. ${ }^{14}$

Jarraian, euskal ondare zaharreko bakunen datuak autoreka aztertuko ditugu (ikus 6. taula). Lehenik eta behin, datu orokorren analisia egitean aurreratutako ondorioak azaldu eta sakondu behar ditugu. Hain zuzen, $R$ Sko kopuru altua $(128, \% 66)$ da nabarmenena, hitzen kopuru osoari dagokionez aurretik dituen Lazarraga (125, \%43) eta Etxepareri $(99, \% 45)$ gailentzen baitzaie. RSk bi hauekiko duen aldea hiru silabako hitzetan $(42, \% 33)$ da agerikoena, ia Oihenarten kopurura iristen da-eta (43, \%26). Gainera, aurretiaz ondorioztatu dugun bezala, Leizarragak, duen hitz ko-

\section{6. taula}

Euskara Arkaikoko ondare zaharreko hitz bakunen nolakotasuna testuz testu

\begin{tabular}{|c|c|c|c|c|c|c|c|c|c|c|c|c|}
\hline $\begin{array}{c}\text { Ondare zaharreko } \\
\text { bakunak }\end{array}$ & RS & $\mathrm{Zgz}$ & Is & $\mathrm{Zm}$ & $\operatorname{Etxp}$ & Oih & Bela & Leiz & Mis & Laz & Bet & Guzt. \\
\hline Monosilabikoak & 5 & 3 & 0 & 3 & 4 & 6 & 2 & 9 & 0 & 6 & 3 & $41(11)$ \\
\hline Bi silabakoak & 73 & 50 & 26 & 16 & 68 & 93 & 12 & 123 & 14 & 71 & 22 & $568(197)$ \\
\hline Hiru silabakoak & 42 & 10 & 7 & 5 & 20 & 43 & 4 & 104 & 3 & 35 & 8 & $281(163)$ \\
\hline Lau silabakoak & 7 & 5 & 2 & 1 & 5 & 22 & 1 & 32 & 0 & 12 & 4 & $91(51)$ \\
\hline Bost silabakoak & 1 & 1 & 1 & 0 & 2 & 2 & 0 & 7 & 0 & 1 & 0 & $15(8)$ \\
\hline Guztira (430) & $\begin{array}{r}128 \\
\% 66\end{array}$ & $\begin{array}{r}69 \\
\% 57\end{array}$ & $\begin{array}{r}36 \\
\% 43\end{array}$ & $\begin{array}{r}25 \\
\% 78\end{array}$ & $\begin{array}{r}99 \\
\% 45\end{array}$ & $\begin{array}{r}166 \\
\% 53\end{array}$ & $\begin{array}{r}19 \\
\% 63\end{array}$ & $\begin{array}{r}275 \\
\% 37\end{array}$ & $\begin{array}{r}17 \\
\% 59\end{array}$ & $\begin{array}{r}125 \\
\% 43\end{array}$ & $\begin{array}{r}37 \\
\% 53\end{array}$ & 996 \\
\hline Hitzak guztira (1170) & 194 & 121 & 83 & 32 & 218 & 314 & 30 & 752 & 29 & 290 & 70 & 2.133 \\
\hline
\end{tabular}

${ }^{14}$ Lakarrak ere (2009: 589), azken 500 urteetako euskarari dagokionean, bisilabikoak nagusi direla (monosilabikoak baino ia hamalau aldiz gehiago) adierazten du. 
puru osoa (752) larria izanik, horrenbeste euskal ondare zaharreko bakun (275) ez duela esan daiteke. Baina, edozelan ere, euskal ondare zaharreko bakun guztien \%64 erabiltzen du (430etik 275). Eta bigarrenak, Oihenartek, ostera, \%39 erabiltzen du ozta-ozta (166). RSko hitz soil luzeen (hiru silabakoen) ugaritasuna baliteke bere nolakotasun kronologikoarekin erlazionatuta egotea. Hau da, $R S$ kronologikoki testurik arkaikoena izanik, posible da bertan deribazio fase zaharra islatu eta, hitz soil luze zenbait lehenagoko konplexuak izatea (ikus 4.1.3.3. atala).

Bukatzeko, euskal ondare zaharreko 430 hitz bakun hauetako asko autore bik edo gehiagok erabiltzen dituztela da aipatzekoa. Horren adierazle da hitz hauen agerraldi kopurua 996 izatea (autore bakoitzak hitz bat behin baino gehiagotan erabil dezakeela kontuan hartu gabe). Ondare zaharreko hitzen berragertzea hitz laburren kasuan da bereziki ohikoagoa; oro har, silaba bat eta bikoen artean hitzak behin edo gehiagotan errepikatzen diren bitartean, hiru, lau eta bost silabakoen artean behin errepikatzen dira asko jota.

\subsubsection{Euskal ondare zaharreko eratorriak}

Arestian azaldu dugun bezala, 157 dira gure corpusean euskal ondare zaharreko eratorritzat jo ditugun hitzak. Ohiko bideari jarraituz, eratorritzat hartu dira lexema bati hizkiak gehituz sortutako lexema berriak (Euskaltzaindia 2002: 42). Euskalari batzuek eratorrien artean aztertu izan dituzten (ikus Villasante 1974) alde, behe ( $p e$ ), gabe, gai, gaitz, kide, ondo... hitz beregain edo lokabeak bailiran hartu dira, eta, konposatuen atalean ikusiko ditugu. Sailkatze lan honetan, bete-betean jarraitu ez baditugu ere, Villasante (1974) eta Azkarate (1990) izan ditugu oinarri, eta, Sarasolaren (1997) lana ere hartu dugu kontuan.

Aipaturiko 157 eratorri hauen barruan 39 hizki desberdin aurkitu ditugu, 38 atzizki eta aurrizki bakarra (ikus 7. taula). Forma berdina izanda ere, adiera semantiko desberdina duten hizkiak (ikus $-k a$ eta $-k i$ atzizkiak) bereizirik zenbatu eta aurkeztuko ditugu. Hizki hauetarik gehienak (28) euskal ondare zaharrekoak dira (ikus 7. taulako barratxorik gabekoak). Beste batzuk (11), ostera, jatorri erromanikoa daukate ${ }^{15}$ (ikus 7. taulako barratxo artekoak).

Jatorri mailegatua izanda ere, hizki apur batzuek oinarri mailegatuak ez ezik euskal ondare zaharreko oinarriak ere hartzen dituzte. Eratorpena euskal ondare zaharrekoetara neurri esanguratsu batean (\%25etik gora) zabaldu duten hizki mailegatuak hizki bertakotutzat jo dira, alegia, -keria, -men, eta erre-. Eta, beraz, hizki hauez eta euskal ondare zaharreko oinarriez osatutako hitzak euskal ondare zaharreko eratorritzat hartu dira. Baina, hizki hauek mailegu eratorrien atalean ere berrikusiko ditugu aurrerago. Izan ere, hizki mailegatu hauez eta oinarri mailegatuz osatutako hitzak mailegu eratorritzat hartu ditugu, eratorpen hizki mailegatu hauek bertakotutzat ostean, mailegu soilak zirenak berranalisiaren bitartez mailegu eratorri bihur daitezkeelako. Bestalde, corpuseko hitzen artean mailegatutako beste zenbait hizki ere aurki daiteke. Kasu hauetan, hizkiek oinarria ere beti mailegatua dutenez gero, hitz mai-

15 Eratorpen atzizkien inguruko informazioa Villasante (1974), eta Segura eta Etxebarriaren (2001) lanetatik jaso da bereziki. 
legatutzat jo dira, eta, mailegu bakunen multzoan sartu ditugu; hain zuzen, -antza, -ari,-dura, -mendu, -os(o), -tate (-dade), -tzia eta -zio atzizkiez osatutakoak. ${ }^{16}$

\section{7. taula}

Euskara Arkaikoko eratorpen hizkien nolakotasuna

\begin{tabular}{|c|c|c|c|}
\hline Hizkiak (adibidea) & Kopurua & Hizkiak (adibidea) & Kopurua \\
\hline 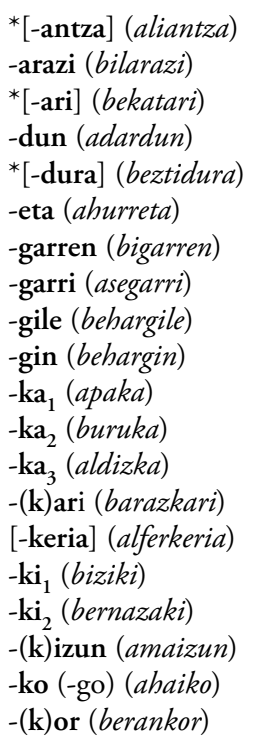 & $\begin{array}{l}{[2]} \\
9[5] \\
9[8] \\
5[2] \\
{[3]} \\
1 \\
4 \\
6[1] \\
2[1] \\
1 \\
1 \\
3 \\
2 \\
5 \\
3[-2] \\
19[6] \\
2[1] \\
4 \\
1 \\
4\end{array}$ & $\begin{array}{l}\text {-kunde (aiberkunde) } \\
\text {-kuntza (azarkuntza) } \\
\text {-le (atzemaile) } \\
\text { [-men] (aipamen) } \\
\text { *[-mendu] (adimendu) } \\
\text { *[-os(o)] (animoso) } \\
\text {-ro (biziro) } \\
\text {-(t)ar (barrundiar) } \\
\text {-tasun (arintasun) } \\
\text { *[-tate/-dade] (autoritate) } \\
\text {-ti (beldurti) } \\
\text {-tsu (bizartsu) } \\
\text {-txo (arrosatxo) } \\
\text {-tza/-tze (bizitza) } \\
\text {-tzaile (biltzaile) } \\
\text { *[-tzia] (abondantzia) } \\
\text { *[-zio] (admirazio) } \\
\text {-(z)ko (ahozko) } \\
\text { [erre-] (arregin) }\end{array}$ & $\begin{array}{c}{[1]} \\
{[1]} \\
3[1] \\
4[2] \\
{[6]} \\
{[8]} \\
2 \\
1 \\
16[3] \\
{[8]} \\
3[1] \\
6[2] \\
4[1] \\
6 \\
16[12] \\
{[5]} \\
{[12]} \\
25[5] \\
1\end{array}$ \\
\hline \multicolumn{3}{|l|}{ Guztira } & 157 [99] \\
\hline
\end{tabular}

Eratorpen atzizki hauetatik guztietatik ez dira asko gure corpusean hitz kopuru esanguratsua daukatenak. Euskal ondare zaharrekoak diren 28 hizkiek 153 agerraldi dituzte, eta, euskal ondare zaharreko oinarriak hartzen dituzten 3 hizki mailegatuek, ostera, 4 agerraldi. Kopurua hizkirik hizki behatuz, eskuarki izenlagunak sortzeko baliatzen den $-(z) k o$ atzizkiak (25) soilik gainditzen du hogei hitzen langa. Eta hau flexio morfema batetik eratorritako atzizkia dela esan beharra dago. Atzizki honekin sortutako bost berbatik batek oinarri mailegatua du. Hamar eta hogei agerraldi dituztenen artean lau atzizki aurki daitezke: ${ }^{17}-k i_{1}$, (19 [6]), -tasun (16 [3]), -tzaile (16 [12]), eta -zio [12]. Eta hamar atzizki gehiagok daukate bost agerralditatik gora: -arazi (9 [5]), -ari (9 [8]), -os(o) [8], -tate [8], -garri (6[1]), -mendu [6], -tsu (6 [2]), -tza (6), -tzia [5] eta -dun (5 [2]). Hauetarik batzuk maileguak direla gogoratu beharra dago. Agerraldi bakarra duten hizkien multzoa da ugariena (zortzi hizki).

\footnotetext{
16 Euskal ondare zaharreko eratorriak sortzen dituzten hizkiak bildu ditugun 7. taulan, aipatu hizki hauek ere jaso ditugu, izarño batez markaturik beti ere.

17 Barratxo artean ageri diren zenbakiek oinarri mailegatudun kopurua adierazten dute.
} 
Emaitza hauek zuzenean konparatzeko, Euskara Arkaikoko eratorpen atzizkien inguruko ikerketa zabalik egin ez bada ere, Sarasolak (1997: 636) xIx zein Xx. mendera arteko euskal eratorpen atzizkien maiztasun absolutuak ditu jasoak. Eta haren arabera, XIX. mendera bitartean agerraldi gehien dituzten lehenengo hamalau atzizkiak honako hauek dira: -ko (211), -arazi (175), -tasun (165), -garri (140), -ka (133), -ki (109), -ari (104), -tzaile (91) -tsu (90), -le (74), -aldi (73), -dun (61), -txo (61), -tza (60). Hizki hauetatik gehienak gure corpus xumeko bost agerralditik gorako zerrendan ere badaude. $-k a$, -le, -aldi eta -txo atzizkiak dira falta diren bakarrak. Eta, gainera, $-k a-$ ren inguruan esan beharra dago guk ere Sarasolak egin bide duen bezala hizki honen adiera guztiak batera aztertuko bagenitu, gurean ere agerraldi ugaritsuenen zerrenda horretan egongo litzatekeela. Gainerakoei dagokienez, -txo lautan eta -le hirutan ageri dira, eta, -aldi, ${ }^{18}$ berriz, behin ere ez. Printzipioz, azken datu hau da harritzekoena. Baina, Sarasolak (1997: 637) euskal atzizki nagusienen modernotasunaren inguruan erakusten duen diagraman, berrienen artean ageri da -aldi. Analisia kontrako norantzan eginez gero, agerraldi kopuru altua duten gure hizkien zerrendatik Sarasolarenean falta direnak -os(o), -tate, -zio eta -mendu dira. Lehenengo biak ez ditu Sarasolak bere ikerketan biltzen, euskal atzizkitzat joko ez dituelako beharbada. Eta -zio eta, batez ere, -mendu hizkiena ez da harritzekoa, xvI. mendetik aurrera oso tradizio urria izan dute-eta. Bestalde, aipatzekoa da gure corpusean gorago erakutsitako horiek baino agerraldi gutxiago dituzten hizkiek ere $(-k e r i a,-k o r,-t i,-z a l e .$.$) proportzioan emaitza$ nahiko parekoak dituztela Sarasolarenean. Eta azkenik, aipatzekoa da baita gurean ere badirela Sarasolak biltzen ez dituen hizki batzuk (-gile, -gin, -ro...) eta, alderantziz ere bai (-aldi, -era, -gailu, -koi, -zale...). Sarasolaren azken atzizki hauek duten agerraldi kopuru txikia kontuan hartuta, gurean ez aurkitzea ez da horren harritzekoa.

Euskara Arkaikoari buruzkoa izan ez arren, Oyharçabal-ek ere (1996) badauka ikerlan bat eratorpen atzizkiei buruz. Bertan, Materraren testuko atzizkiak identifikatu eta aztertzen ditu, 28 atzizki aurkitzen dituelarik: -antza, -ari (1), -ari (2), -dura, -garri, -ka, -(k)eria, -(k)eta, -ki (1), -ki (2), -(k)izun, -(kh)oi, -kuntza, -le, -mendu, -os, -pen, -ro, -tasun, -ti, -tsu, -to, -tza, -tzaile, -tze, -zale, -zarre, -zia. Hauetarik gehientsuenak gure corpusean ere aurki daitezke. Materraren atzizkien artean -tasun, $-k i$, -tzaile, eta -mendu dira erabilienak. Gurean ere bost agerralditik gorakoak dira hizki hauek guztiak. Nabarmentzekoa da XVII. mendeko autore honen -tasun atzizkiaren erabilera naroa, gurean Leizarragaren obran soilik aurkitu dugu-eta.

Hizkien ondoko hitza behatuz gero, jatorri erromanikoa duten hizkiek oinarri mailegatuak hartzeko joera handia dutela nabaria da, guztira dituzten 61 agerraldietatik gehienek (56) oinarri mailegatua dute-eta (adib.: blasfemari, burlakeria, barkamen...). Ondare zaharreko hizkien artean, oinarrian ohikoena jatorri bereko lexemak aurkitzea bada ere (adib.: bereizgarri, berritasun...), atzizki zenbaitek eratorpena maileguetara ere zabaldu dutela antzeman daiteke: 153 agerralditik 43k (ia hirutik batek) daukate oinarri mailegatua. -arazi (adib.: altxarazi, beharazi...) eta -tzaile (adib.: aditzaile, blasfematzaile...) dira oinarri mailegatuak hartzeko joera handia (erdia baino gehiago mailegatuak) duten euskal hizkiak. Badago, kontrara, jatorri erromanikoa izanda euskal ondareko oinarria bakarrik hartzen duenik, alegia, erre- (arregin). Hala ere, hau ez da oso adierazgarria, agerraldiak oso gutxi dira-eta (erakutsitakoa soilik).

18 Sarasolak aldi atzizkitzat jo arren, guk hitz lokabetzat hartuko genuke. 
Lehian egon litezkeen hizkiez den bezainbatean, badago zer esanik, adiera semantiko bereko hitzak eratzeko balio duten hizkiak aurki daitezke-eta:

a) -os(o) eta -tsu: mailegatua da lehenengoa eta euskal ondare zaharrekoa bigarrena, baina, biak ala biak ugaritasuna adierazten duten izenondoak eratzeko balio dute. $-o s(o)$ zortzi aldiz ageri da gure corpusean eta, zortzietan oinarri mailegatuekin (adib.: animos (Etxp), eta birtuoso (Laz)). -tsu, ostera, gehiene$\tan$ (lautan) ondare zaharreko berbekin ageri den arren (bizartsu (RS, Oih)), mailegatuekin ere (birritan) batzen da (bertutetsu, boteretsu (Leiz)). Aurkitutako hitz hauek ez dute bariazio dialektalik erakusten. Villasantek ematen dituen (1974: 114-115) Axularren adibideetan ere -os(o) beti oinarri mailegatuekin ageri da, baina, bi atzizki hauek lehian direnaren adibide argirik ere aurkezten du: malizios vs maliziatsu.

b) -tate eta -tasun: kasu honetan ere jatorri ezberdineko atzizki bi hauek oinarriaren tasuna edo ezaugarria adierazten duten izen abstraktuak sortzeko baliatzen dira. -tate oinarri mailegatuekin ageri da gure corpusean beti (abildade, autoritate...) eta, -tasun, berriz, ia beti euskal ondare zaharrekoekin (anaitasun, aniztasun...). Baina, oinarri mailegatudun hiru adibide ere aurki ditzakegu: apostolutasun, arintasun eta baxotasun. Villasantek (1974: 126), ostera, -tate hitz apur batzuetan oinarri euskaldunekin ere batzen dela erakusten du: jakitate, bakartade, egitade, gogortade. -tate hizkia corpus honetako obra askotan ageri da; ordea, -tasun Leizarragak bakarrik erabiltzen du. Beraz, bi hizki hauen arteko lehiakortasuna egon daitekeen arren, gure corpusean ez da argi islatzen.

c) -tzaile eta -le (eta -ari): lehenengo biak aditz iragankor bat oinarri hartuta agente edo egiletasuna adierazteko erabili ohi dira. Azkenak, egiletasuna baino ofizioa edo langaia adierazten du eskuarki. Mugikak (1978) zein Villasantek (1974) azaltzen duten legez, lehenengo bien artean, badaude arau morfologikoak hitz batek bata edo bestea aukeratzeko. Labur-labur eta azaletik azalduta, TU partizipioarekin amaitutako aditzek -tzaile hartu ohi dute eta bestelakoekin ( $-n$ eta $-i$ batzuk) bukatutakoek -le. Baina, batzuetan «anomaliak» deritzen kasuak izaten dira, eta, gure corpusean ere baliteke zalantzakoak diren kasuren batzuetan idazleek -le hizkia hautatu izana: begirale? (Leiz). xvir. mendeko Axularrek ere (Villasante 1974: 137) begiraille baliatzen du. Hala ere, -tzaile askozaz gehiago ageri da gure laginean: barautzaile, biltzaile... Bestalde, -ari hizkia gehienetan izenekin (auzilari...) batzen den arren, batzuetan aditzekin ere (pentsalari...) ageri ohi da, -tzaile-l-le hizkiei euren eremua bereganatuz. Gure corpusean ere badago horren erakuslerik: akusari (Etxp) (vs akusatzaile) eta barreiari (Oih) (vs barreiatzaile).

d) -gile eta -gin: bi hizki hauek egiletasuna adierazi ohi dute, baina, ekoizle edo fabrikatzaile adiera zehatzarekin. Mugikak (1978: 128) esaten duen legez, biek jatorri bera dutela dirudi, alegia, egile. Gure corpusa bi hizki hauek lehian daudenaren argibide izan daiteke. Bertan, behargile (Isas, Oih) zein behargin $(R S)$ aurki ditzakegu.

e) $-k i_{1}$ eta $-r o$ : izen edo izenondoekin batuz modu aditzondoak sortzeko baliatzen dira. - $k i$ hizkia 19 aldiz agertzen da gure corpusean eta, ostera, -ro birritan soilik. -ki, oro har, Bizkaitik kanpo erabiltzen dela esan ohi da (ikus Villa- 
sante 1974: 96), eta, gure corpuseko Mendebaldeko testuetan behin bakarrik aurkitzen da; baina, -ro behin ere ez. Edozelan ere, gure corpusak Iparraldean -ki eta -ro oinarri berdinarekin erabiltzen zirela erakusten du: biziki (Leiz) vs biziro (Oih).

f) -mendu eta -men: hizki bi hauei jatorri latindar bera aitortzen zaien arren, Mugikak (1978), Villasantek (1974) ez bezala, bereizita aztertzen ditu, amankomunean daukaten egintza adiera nagusiarekin batera, bakoitzak beste esanahi bat ere izan dezakeelako. Gure corpusean -mendu hizkiaren sei agerraldiek zein -men-en lauek egintza adiera bera izanda ere, bereizita analizatu ditugu, lehenengoak beti oinarri mailegatuak hartzen dituelako (arrazoinamendu, atrebimentu...) eta bigarrenak aldiz bietarik (ahamen, barkamen...). Beraz, bakoitzak jatorri ezberdineko oinarriak hartzeko joera izan dezakeela pentsa daitekeen arren, batzuetan behintzat lehian ere badaudela ondoriozta daiteke. Esaterako, Leizarragak biak baliatzen ditu oinarri mailegatuekin: aipamen, adimendu eta abar.

g) -kunde eta -kuntza: bi hizki hauen adiera nagusia ere egintza da. Gure corpusean agerraldi bana izanda, aiherkunde (Leiz) eta azarkuntza $(R S)$, gaitza da ondorio esanguratsurik ateratzea. Bariazio dialektalaren gainean, Mujikak (1978: 1985) dio «mientras -kunde parece tener más extensión en la geografía dialectal del euskara, -kuntza tiene más vigencia en los dialectos meridionales $(\mathrm{AN}, \mathrm{B}, \mathrm{G}) »$. Gure corpuseko adibide apurrak honekin bat datoz, -kunde Leizarragaren obran eta -kuntza RSn ageri baitira. Baina, esan bezala, agerraldi kopuru urria dela-eta ez da esanguratsua. Bukatzeko, batak zein besteak oinarria mailegatua (baina oso-oso zaharra) dutela esan beharra dago.

Euskal ondare zaharreko hitz eratorriak autoreka aztertzera jauzi eginda (ikus 8. taula), lehenik eta behin, datu orokorrak ikertzean ateratako ondorioak ekarriko ditugu gogora. Autore bakoitzaren hitz kopuru osoa kontuan hartuta, Leizarragaren ugaritasuna (\%14) eta Lazarragaren urritasuna (\%2) dira nabarmentzekoenak. Hala ere, gainerako testu handien artean, Oihenart (\%11) zein $R S(\% 9)$ eta Etxepareren (\%5) arteko aldea ere handia da. Testu txikietan handienek, hau da, Zalgize, Isasti eta Betolatzak \%6-9 bitarteko kopurua dute. Analisia eratorrien barruan kokatuz gero, Leizarragak corpuseko 157 hitz eratorrietatik 106 erabiltzen ditu (\%68). Eta, alde handia dago gainerakoekin alderatuz. Izan ere, bigarrenak, Oihenartek hamarretik bi inguru (\%22) erabiltzen ditu, 34 zehazki. Oihenart eta beste guztienak batuta ere (89), ez dira Leizarragaren hitz eratorri kopurura iristen. Lehenago esan bezala, Lazarragaren eratorrien urritasuna oso adierazgarria da 6 baino ez ditu-eta (eratorri kopuru osoaren \%4 eskas).

Eratorpen atzizkiei dagokienez, berauen analisi zehatzagoak orain arte ateratako ondorio nagusiak hobeto ulertzen laguntzen du. Hona hemen azterketa honen emaitza esanguratsuenak:

- Hainbat hizki (-arazi, $-k a_{2}$, -tasun, erre-) Leizarragak bakarrik erabiltzen ditu. Eta beste hizki batzuen $\left(-d u r a,-k i_{1},-z i o,-z k o\right)$ erabileran ere alde handiarekin da nagusi.

- Hainbat hizki (-dun, -garri, -keria, -ti, -tsu) Leizarraga, Oihenart eta $R S \mathrm{n}$ ageri dira, eta, ia bakarrik horietan. 


\section{8. taula}

Euskara Arkaikoko eratorpen hizkien nolakotasuna testuz testu

\begin{tabular}{|c|c|c|c|c|c|c|c|c|c|c|c|c|}
\hline & RS & $\mathrm{Zgz}$ & Is & $\mathrm{Zm}$ & Etxp & Oih & Bela & Leiz & Mis & $\mathbf{L a z}$ & Bet & Guzt. \\
\hline Atzizkiak & & & & & & & & & & & & \\
\hline$*[$-antza $]$ & 0 & 0 & 0 & 0 & 0 & 0 & 0 & 1 & 1 & 0 & 0 & [2] \\
\hline -arazi & 0 & 0 & 0 & 0 & 0 & 0 & 0 & $9[5]$ & 0 & 0 & 0 & $9[5]$ \\
\hline$*[-$ ari $]$ & {$[1]$} & {$[2]$} & 0 & [1] & [3] & [3] & 0 & {$[2]$} & 0 & {$[1]$} & {$[1]$} & [14] \\
\hline -dun & 2 & 1 & 0 & 0 & 0 & $2[1]$ & 0 & $2[1]$ & 0 & 0 & 0 & $7[2]$ \\
\hline$*[$-dura $]$ & 0 & 0 & 0 & 0 & 0 & 0 & 0 & {$[3]$} & 0 & [1] & 0 & [4] \\
\hline -eta & 0 & 0 & 0 & 0 & 0 & 1 & 0 & 0 & 0 & 0 & 0 & 1 \\
\hline -garren & 2 & 0 & 0 & 0 & 1 & 0 & 0 & 3 & 0 & 0 & 3 & 9 \\
\hline -garri & 1 & 1 & 0 & 0 & 0 & 2 & 0 & 3 [1] & 0 & 0 & 0 & $7[1]$ \\
\hline -gile & 0 & 0 & $2[1]$ & 0 & 0 & 1 & 0 & 0 & 0 & 0 & 0 & $3[1]$ \\
\hline- gin & 1 & 0 & 0 & 0 & 0 & 0 & 0 & 0 & 0 & 0 & 0 & 1 \\
\hline$-\mathrm{ka}_{1}$ & $1[1]$ & 0 & 0 & 0 & 0 & 0 & 0 & 0 & 0 & 0 & 0 & $1[1]$ \\
\hline$-\mathrm{ka}_{2}$ & 0 & 0 & 0 & 0 & 0 & 0 & 0 & 3 & 0 & 0 & 0 & 3 \\
\hline$-\mathrm{ka}_{3}$ & 0 & 0 & 0 & 0 & 0 & 1 & 0 & 1 & 0 & 0 & 0 & 2 \\
\hline -(k)ari & 1 & $1[1]$ & 1 & 0 & $1[1]$ & 1 & 0 & 2 & 0 & 0 & 0 & $7[2]$ \\
\hline [-keria] & {$[1]$} & 0 & 0 & 0 & 0 & 1 & 0 & $2[1]$ & 0 & 0 & 0 & $4[2]$ \\
\hline$-k i_{1}$ & 0 & 0 & 0 & 0 & $4[3]$ & $5[1]$ & 0 & $14[5]$ & 0 & 1 & 0 & 24 [9] \\
\hline$-\mathrm{ki}_{2}$ & 1 & 0 & 0 & 0 & 0 & 0 & 0 & 1 & 0 & 0 & 0 & 2 \\
\hline -(k)izun & 0 & $2[2]$ & 0 & 0 & 1 & $4[2]$ & 0 & 1 & 0 & 0 & 0 & $8[4]$ \\
\hline -ko (go) & 0 & 0 & 0 & 0 & 0 & 0 & 0 & 1 & 0 & 0 & 0 & 1 \\
\hline$-(\mathbf{k})$ or & 0 & 0 & 0 & 0 & 0 & 3 & 0 & 2 & 0 & 0 & 0 & 5 \\
\hline -kunde & 0 & 0 & 0 & 0 & 0 & 0 & 0 & [1] & 0 & 0 & 0 & [1] \\
\hline -kuntza & {$[1]$} & 0 & 0 & 0 & 0 & 0 & 0 & 0 & 0 & 0 & 0 & [1] \\
\hline -le & 0 & 1 & 0 & 0 & 0 & 0 & 0 & 3 & 0 & 0 & 0 & 4 \\
\hline [-men] & 0 & 1 & 0 & 0 & {$[1]$} & 1 & 0 & $2[1]$ & 0 & 0 & 0 & $5[2]$ \\
\hline$*[-$ mendu $]$ & 0 & 0 & 0 & 0 & [2] & 0 & 0 & {$[4]$} & 0 & [2] & 0 & [8] \\
\hline$*[-o s(0)]$ & 0 & 0 & 0 & 0 & {$[2]$} & 0 & 0 & {$[4]$} & 0 & {$[2]$} & 0 & [8] \\
\hline- ro & 0 & 0 & 1 & 0 & 0 & 2 & 0 & 0 & 0 & 0 & 0 & 3 \\
\hline$-(t) a r$ & 0 & 0 & 0 & 0 & 0 & 0 & 0 & 0 & 0 & 1 & 0 & 1 \\
\hline -tasun & 0 & 0 & 0 & 0 & 0 & 0 & 0 & $16[3]$ & 0 & 0 & 0 & $16[3]$ \\
\hline$*[$-tate/dade $]$ & 0 & 0 & 0 & [1] & {$[2]$} & 0 & {$[1]$} & {$[6]$} & {$[1]$} & {$[3]$} & [3] & {$[17]$} \\
\hline$-\mathrm{ti}$ & 1 & 0 & 0 & 0 & 0 & $2[1]$ & 0 & 1 & 0 & 0 & 0 & $4[1]$ \\
\hline- tsu & 1 & 0 & 0 & 0 & 0 & 3 & 0 & $3[2]$ & 0 & 0 & 0 & $7[2]$ \\
\hline$-t x o$ & 0 & 0 & 0 & 0 & 0 & 0 & 0 & 3 & 0 & $1[1]$ & 0 & $4[1]$ \\
\hline- tza/tze & 2 & 0 & 0 & 1 & 1 & 0 & 1 & 2 & 0 & 1 & 1 & 9 \\
\hline -tzaile & 0 & 0 & $2[2]$ & 0 & 0 & $5[2]$ & 0 & 11 [9] & 0 & 0 & 0 & 18 [13] \\
\hline$*[$-tzia $]$ & 0 & 0 & 0 & 0 & 0 & 0 & 0 & [5] & 0 & [1] & 0 & {$[6]$} \\
\hline$*[$-zio $]$ & 0 & 0 & 0 & 0 & 0 & 0 & 0 & [11] & 0 & {$[1]$} & {$[2]$} & [14] \\
\hline -(z)ko & 3 & 0 & 1 & 0 & $2[1]$ & 0 & 0 & $21[5]$ & 0 & 2 & $2[1]$ & 31 [7] \\
\hline $\begin{array}{l}\text { Aurrizkiak } \\
\text { [erre-] }\end{array}$ & 0 & 0 & 0 & 0 & 0 & 0 & 0 & 1 & 0 & 0 & 0 & 1 \\
\hline $\begin{array}{l}\text { Guztira } \\
(157)\end{array}$ & 17 & 7 & 7 & 1 & 10 & 34 & 1 & 106 & 0 & 6 & 6 & 195 \\
\hline $\begin{array}{l}\text { Hitzak guztira } \\
(1170)\end{array}$ & 194 & 121 & 83 & 32 & 218 & 314 & 30 & 752 & 29 & 290 & 70 & 2.133 \\
\hline
\end{tabular}


- Hainbat hizki (-kizun, -kor, -ro, -ti) Oihenartek erabiltzen ditu gehien.

- -gile Isastiren testuan ageri da gehienetan (bi agerraldi); behin Oihenartenean.

- -(k)izun Oihenart eta Zalgize zuberotarrek erabiltzen dute gehienetan (Etxepare eta Leizarragak ere bai).

- Mendebaldeko testuetan behin bakarrik ageri da $-k i_{1}$ atzizkia.

— Lazarraga da Leizarragaren ostean hizki mailegatu gehien darabilena. Eta

Oihenartek Lazarraga eta Etxeparek baino hizki mailegatu gutxiago du.

Laburbilduz, beraz, Leizarragaren hitz eratorrien ugaritasuna da bereziki azpimarragarriena. Eta, gure iritziz, eratorpenaren erabilera naro honek testu motarekin dauka lotura zuzena. Izan ere, hizkuntzalari zenbaitek, tartean Sarasolak (1997: 635), behin baino gehiagotan aldarrikatu dute hizkuntza guztietan badagoela erlazio hertsi bat idazkera jasoaren eta hitz eratorrien ugaritasunaren artean. Eta Leizarragaren Testamentu Berria bezalako testuek ezinbestean behar dute idazkera jasoa eta, ondorioz, hitz konplexuen erabilera.

Bukatzeko, hitz eratorri berdinak autore desberdinetan nahiko gutxi errepikatzen direla esan daiteke. Horren adierazle da hitz eratorri ezberdinen kopuruaren (157) eta hitz eratorrien agerraldi kopuru osoaren (195) arteko alde txikia. -kizun, -ari eta -tate atzizkiak dira autoreen artean gehien errepikatzen direnak. Honek guztiak erakus lezake ez zirela oso erabiliak, eguneroko bizian are gutxiago, eta itzulpenek eta literatur-testuek eragindako hitzberrigintza dugula.

\subsubsection{Euskal ondare zaharreko konposatuak}

Ezer baino lehen, hitzak konposatutzat hartzeko erabilitako irizpideak eta hartutako erabakiak azalduko ditugu. Beraz, hitz konposatutzat hartu ditugu lexema beregain biren konbinaketaz sortutako lexema berriak (Euskaltzaindia 2002: 42). Hitz eratorrien atalean aipatu dugun legez, bereziki euskal morfologialari garaikideei jarraituz (ikus Azkarate 1990), sarritan eratorpenaren eta hitz elkarketaren artean kokatu ohi diren alde, behe (pe), gabe, gai, gaitz, kide, eta ondo hitz beregain edo lokabetzat jo ditugu.

Beste alde batetik, hitz elkartu motei dagokienez, Villasante (1974) oinarri hartuta, lehenik hitz konposatu guztiak sailkatzeko bost multzo zehaztu genituen: mendekotasunezkoak, kopulatiboak, exozentrikoak, justaposiziozkoak eta onomatopeiazkoak. Baina, multzokatze lana bukatu bezain laster sailkapen hau gure corpuseko hitzak sailkatzeko egokiena ez zela ohartu ginen, ia hitz guztiak talde bi$\tan$ (mendekotasunezkoak edo justaposiziozkoak) banatzen baitziren. Hori dela eta, gure corpusarentzat egokiagoa izango zen beste sailkapen baten bilatzeari ekin genion eta, Euskaltzaindiaren hitz elkartuen inguruko lanen artean aurkitu genuen. Hitz-elkarketa/4 (Zalbide 1992) lanean zehazten diren 17 hitz motatatik 9 behar izan ditugu. Eta hauei beste bi gehitu dizkiegu, justaposiziozkoak eta gramatikalak, hain zuzen ere (ikus 9. taula). Gainera, Eguzki-lore modukoak deritzon mendekotasunezkoen multzoan hitz kopuru handia batzen dela ikusita, Azkarate eta Perez-en (2013) lanaren laguntzaz bertako hitzak beste hiru taldetan banatu ditugu. Horrela, gure corpuseko hitz elkartuak hobeto deskribatuko dituen sailkapen bat osatu dugula uste dugu. 


\section{9. taula}

Euskara Arkaikoko konposaketaren nolakotasuna

\begin{tabular}{|l|c|}
\hline \multicolumn{1}{|c|}{ Konposatuak } & Kopurua \\
\hline Eguzki-lore modukoak: & \\
Behi-esne moduko izen elkarteak & 9 \\
Mugakizun bereziko izen elkarteak (adondo) & $33[3]$ \\
Mugatzaile bereziko izen elkarteak (behatz) & 2 \\
Jarleku modukoak & $4[2]$ \\
Dvandva elkarteak (aitama) & 1 \\
Atributu eta koordinazio elkarteak (aitajaun) & $4[1]$ \\
Bahuvrîhi elkarteak (buruzuri) & 5 \\
Izaera elkarteak (asegaitz) & $2[1]$ \\
Lotsagabe, lofalta modukoak & $10[3]$ \\
Bikoiztapenak (baratxe-baratxe) & 1 \\
Aditz konposatuak (berantetsi) & 3 \\
Justaposiziozkoak (asteme) & $10[1]$ \\
Sailkatu gabeak (gramatikalak) (alabaina) & 7 \\
\hline Guztira & $91[11]$ \\
\hline
\end{tabular}

Hitz konposatuen hautatze eta sailkatze irizpideak behin azalduta, datuak aztertzeari ekingo diogu. Datu orokorrak aztertzean aipatu dugun legez, hitz konposatuak 91 dira guztira, eta hauetarik gehienak, hirutik bat inguru (33) Eguzki-lore modukoen taldeko Mugakizun bereziko izen elkarteak deritzon multzokoak dira. Bertan mugakizun berezi deritzen alde, ondo, aitzin, behe (be), arte, kide, lagun, modu, kume, edota gai bezalako hitzekin osatutako konposatuak aurki daitezke. Besteak beste, aurrealde, belarrondo, bazkalaitzin, artegi, astazain edo arkume. Hurrengo talderik kopurutsuenak hamar konposatu biltzen dituztenak dira, alegia, lotsagabe, lofalta modukoak eta justaposiziozkoak. Gure corpusean lehenengo motakoak gabe hitzarekin osatzen dira beti: adargabe, arguragabe, bihozgabe eta abar. Eta justaposiziozkoen artean agorril, artizar, asteme, atzerri eta abar aurki ditzakegu. Hau da, elipsirik gabe, osagaien gerturatze soilaz, hitz multzoak izen arrunt bezala berrinterpretatuz sortutakoak. Behi-esne moduko izen elkarteena da hurrengo zabalena, eta, bertan aurki daitezkeen adibideetako batzuk atsotitz, basalore, eta burezur dira. Konposatu hauetan, mendekotasunezko guztietan legez, deklinabide atzizkiren baten (-en edo -ko) ezabaketa gertatu dela antzeman daiteke.

Gainerako konposatu motetan nahikotxo hitz gutxiago ageri da, hamarretik behera, hain zuzen ere. Mendekotasunezkoen artean sar daitezkeen azken taldeak Mugatzaile bereziko izen elkarteak (behatz, buruil) eta Jarleku modukoak (afalordu...) dira. Posesibo ere deitu izan zaien Bahuvrîhi elkarteek norbait edo zerbait nolakoa den adierazi ohi dute; esaterako, burtzoro edo adin handi. Bahuvrîhi elkartekoen oso antzekotzat jo izan dira Izaera elkarteak deritzon motakoak (ikus Zalbide 1992: 58). Izan ere, exozentrikotasun marka berbera eta eskumako osagaia aditzondoa dute. Bahuvrîhi elkartekoek lehenengo osagaia izena (buruzuri) eta besteek aditza izatea (asegaitz) da desberdintasun nagusia. Beste alde batetik, kopulatiboak, aditiboak edo bikote hitzak ere deitu izan zaien dvandva taldearen barruan koordinazio elkarteak 
sartzen dira: aitama (< aita eta ama). Atributu eta koordinazio elkarteek ere, auzia horren argia ez izan arren, batzuetan juntagailu baten ezabaketaz-edo sortutakoak dirudite: ${ }^{19}$ esaterako, aitajaun (< aita eta jaun), amandre (ama eta andre). Azkenik, hitz bera errepikatuz osatutako bikoiztapenak (baratxe-baratxe) eta aditz konposatuak ditugu. Arestian azaldu dugun bezala, aditz lokuzio argiak aditz esapidetzat jo ditugu; aditz konposatuetan Zalbidek (1992: 62) hitz elkarteen lehen atalean kokatzen dituen berantetsi eta begietsi jaso ditugu. Corpus honetako hitz elkarteen osagaiak euskararen ondare zaharrekoak dira gehienetan, hamarretik ia bederatzi.

Atzera egin eta konposatu mota hauek aipatu lehenagoko sailkapenaren arabera hala moduz batu eta neurtuz gero, eguzki-lore eta jarleku modukoak bildu genitzakeen mendekotasunezkoak izango lirateke gehien, berrogeita zortzi zehazki. Dvandva eta agian Atributu eta koordinazio elkarteek osatu lezaketen kopulatiboen taldeak bost konposatu izango lituzke. Exozentrikoak diren Bahuvribi eta Izaera elkarteek zazpi. Eta sailkatu gabeak kenduta gainerakoak (hogeita lau), justaposiziokoen barnean kokatuko genituzke. Sailkapenaren auzia azaltzean esan bezala, beraz, mendekotasunezkoak eta justaposiziozkoak dira gehienak.

Jarraian, hitz konposatuetako datuak autoreka aztertuko ditugu (ikus 10. taula). Lehenik eta behin, datu orokorren azterketaren atalean ateratako ondorioak berrartuko ditugu. Bertan, Lazarragaren eskasiarekin batera, Isastik (12) Zalgizek (4), RSk (7) eta Lazarragak (11) berak baino hitz elkartu gehiago dituela nabarmentzen genuen. Eta begi-bistaz ikusitakoa berretsi egiten dute kalkulu zehatzek. Hain zuzen, hitz

\section{0. taula}

Euskara Arkaikoko konposaketaren nolakotasuna testuz testu

\begin{tabular}{|l|r|r|r|r|r|r|r|r|r|r|r|r|}
\hline & RS & Zgz & Is & Zum & Etxp & Oih & Bela & Leiz & Mis & Laz & Bet & Guzt. \\
\hline Eguzki-lore modukoak & & & & & & & & & & & & \\
$\quad$ Behi-esne modukoak & 0 & 0 & 1 & 0 & 0 & 3 & 0 & 4 & 0 & 1 & 0 & 9 \\
$\quad$ Mugakizun berezikoak & $5[1]$ & 1 & $6[1]$ & 0 & 4 & 9 & 0 & $18[1]$ & 0 & 4 & 0 & 47 \\
$\quad$ Mugatzaile berezikoak & 0 & 0 & 0 & 0 & 0 & 0 & 0 & 1 & 0 & 1 & 0 & 2 \\
Jarleku modukoak & 0 & $1[1]$ & 0 & 0 & $1[1]$ & $1[1]$ & 0 & 2 & 0 & 0 & 0 & 5 \\
Dvandva elkarteak & 0 & 0 & 0 & 0 & 0 & 0 & 0 & 1 & 0 & 0 & 0 & 1 \\
Atributu eta koordinaziozkoak & 0 & 0 & 0 & 0 & $3[1]$ & 0 & 0 & 1 & 0 & 1 & 1 & 6 \\
Bahuvrîhi elkarteak & 1 & 0 & 2 & 0 & 1 & 0 & 0 & 2 & 0 & 1 & 0 & 7 \\
Izaera elkarteak & 0 & 0 & 0 & 0 & 0 & $2[1]$ & $1[1]$ & 0 & 0 & 0 & 0 & 3 \\
Lotsagabe, lofalta modukoak & 0 & 0 & 1 & 0 & 2 & 3 & 0 & $5[3]$ & 0 & 2 & 0 & 13 \\
Bikoiztapenak & 0 & 0 & 1 & 0 & 0 & 0 & 0 & 0 & 0 & 0 & 0 & 1 \\
Aditz konposatuak & 0 & 0 & 0 & 0 & 1 & 1 & 0 & 3 & 0 & 0 & 0 & 5 \\
Justaposiziozkoak & 1 & 1 & 0 & 0 & 2 & 3 & 0 & 7 & 0 & 0 & 0 & 14 \\
Sailkatu gabeak (gramatikalak) & 0 & 1 & 1 & 0 & 5 & 3 & 0 & 6 & 0 & 1 & 0 & 17 \\
\hline Guztira (91) \%8 & 7 & 4 & 12 & 0 & 19 & 25 & 1 & 50 & 0 & 11 & 1 & 130 \\
& $\% 4$ & $\% 3$ & $\% 14$ & & $\% 9$ & $\% 8$ & $\% 3$ & $\% 7$ & & $\% 4$ & $\% 1$ & 13 \\
\hline Hitzak guztira (1170) & 194 & 121 & 83 & 32 & 218 & 314 & 30 & 752 & 29 & 290 & 70 & 2.133 \\
\hline
\end{tabular}

19 Bestela, posible da erlatibo ezabatuak (aita < jaun den aita) izatea. 
guztien artean dagoen konposatuen kopurua (\%8) eta autore bakoitzaren hitz guztien arteko konposatu kopurua alderatuz gero, Lazarraga (\%4) eta RSko (\%4) konposatuen urritasuna argia da. Eta baita Isastik proportzioan (\%14) duen hitz elkartu kopuru altua ere. Isastirekin batera, Oihenart (\%8) eta Etxepare (\%9) dira batazbesteko osoaren langara $(\% 8)$ iritsi edota gainditzen duen bakarrak. Hala eta guztiz ere, Leizarraga da, alde handiarekin, konposatu gehien ere erabiltzen duena, gure lagineko 91 konposatutatik 50 erabiltzen ditu-eta. Bigarrenak, Oihenartek, 25 erabiltzen ditu, hirutik bat baino gutxiago, beraz.

Ondare zaharreko hitz bakunen analisian aipatutakoaren haritik, $R S$ corpuseko testu arkaikoena izanik, bere konposatuen urritasuna konposatu zaharragoen presentziarekin uler liteke. Izan ere, arestian $R S$ n ondare zaharreko hitz soil ugari eta, hauetatik luzeak (hiru silabakoak) nahikotxo daudela ikusi dugu. Eta, hitz soil luze hauek behatuz gero, konposatu (zein eratorri) zaharrak izan litezkeenak ageri dira; besteak beste, ahaide, alargun, atarte, aurpegi, aberats, afari eta abar. Beraz, testu honen garaian, beharbada lehenengo deribazio eta konposaketa fasea amaitzear eta bigarrena (konposatu modernoen sorrera ekarriko lukeena) hasteko zegoela ondorioztatu liteke. Hala ere, ikertzen jarraitu beharra dago aukera hauek baieztatzeko.

Datuok finago aztertuz gero, beste ondorio hauek ere atera daitezke:

- Dvandva motako hitz elkartea Leizarragaren testuan bakarrik ageri da eta, behin baino ez: aitama.

— Leizarragak ia mota guztietako konposatuak ditu; salbuespenak: Izaera elkarteak eta Bikoiztapenak.

- Isastiren konposatuen erdiak mugakizun bereziko mendekotasunezkoak dira: antxume, arkume, astazain, atalondo, bazkalondo, eta bizikide. Halere, gainerako sei konposatuak bost mota desberdinetakoak dira.

- Zumarraga eta Misererean ez dago konposaturik, eta, Bela eta Betolatzarenean bana.

— Mendebaldeko lau testuetan 19 konposatu bakarrik ageri dira (\%21). Urritasun hau, Lazarragari dagokionean, agian lotu liteke egin duen maileguenganako hautuarekin. $R S$ ren hitz elkartu kopuru txikiaren atzean, ostera, bestelako arrazoirik egon daitekeela azaldu dugu gorago.

Bukatzeko, konposatu kopuru osoa (91) eta agerraldi kopuru osoaren (130) artean dagoen tarte txikiak hitz elkartuak autore ezberdinen artean gutxitan errepikatzen direla adierazten du. Gehien errepikatzen direnak mugakizun bereziko mendekotasunezkoak eta justaposizioazkoak dira.

\subsubsection{Maileguak}

Ezer baino lehen, aitortu beharra daukat nire ezagutzaren mugak eta lanabes falta tarteko (euskararen gaineko hiztegi etimologiko zabalik ez), hitzen mailegutasuna eta jatorri zehatza gutxi gorabehera argitzeko, ate ugari jo behar izan ditugula. Bereziki, Arbelaitz (1978), Agud eta Tovar (1988-1995), Segura eta Etxebarria (2001), eta Mitxelena eta Sarasolaren (1987-2005) lanak erabili ditugu. Mailegutzat hartu ditugu ziur kanpoko hizkuntzetatik hartutakoak diren hitzak. Izan ere, Lakarrak 
(2012: 25) azaltzen duen legez, uste dugu edozer dela ondare zaharrekoa besterik frogatzen ez den bitartean.

Eratorrien atalean azaldu dugun legez, jatorri mailegatua duten hizki apur batzuek oinarri mailegatuak ez ezik euskal ondare zaharreko oinarriak ere hartzen dituzte. Eratorpena euskal ondare zaharrekoetara neurri esanguratsu batean (\%25etik gora) zabaldu duten hizki mailegatuak hizki bertakotutzat jo dira, alegia, -keria, -men, eta erre-. Eta beraz, hizki hauez eta ondare zaharreko oinarriez osatutako hitzak euskal ondare zaharreko eratorritzat hartu dira. Baina, badaude hizki mailegatu hauez eta oinarri mailegatuz osatutako hitzak ere, eta hauek mailegutzat hartu ditugu. Bestalde, corpuseko hitzen artean mailegatutako beste zenbait hizki ere aurki daiteke: -antza, -ari,-dura, -mendu, -os(o), -tate (-dade), -tzia eta -zio. ${ }^{20}$ Kasu hauetan, hizkiek oinarria ere beti mailegatua dutenez gero, atzizki hauez osatutako hitzak mailegatutzat jo dira. Guztira, beraz, hauek guztiak eta beste asko gehituta, corpuseko 1170 berbatatik 477 dira maileguak.

Mailegu hauen jatorriari dagokionez, zelterazkoak izan daitezkeen gutxi batzuk kenduta, ia guztiak latinetik edo ondoko erromantzeetatik datoz. ${ }^{21}$ Hau horrela, hitz hauek guztiak sailkatzeko, azpimultzo batzuk finkatzea beharrezkoa sumatu dugu.

\section{1. taula}

Euskara Arkaikoko mailegaketaren nolakotasuna

\begin{tabular}{|l|r|}
\hline \multicolumn{1}{|c|}{ Maileguak } & Kopurua \\
\hline Latina (lat) & 107 \\
Aitzinerromantzea (aitzinerrom) & 79 \\
Hizkuntza erromantzeak (hizk errom): & 175 \\
Gaztelania (gazt) & 108 \\
Gaskoia / Okzitaniera (gask) & 63 \\
Frantsesa (fr) & 2 \\
Hizkuntza erromantze ezberdinak euskalkika & 2 \\
Zeltera (zelt) & 4 \\
Zalantzazkoak (?) & 112 \\
Zalantza orokorra (?) & 21 \\
Latina / aitzinerromantzea / hizk errom? & 44 \\
Latina / aitzinerromantzea? & 10 \\
Aitzinerromantzea / hizk errom? & 4 \\
Aitzinerromantzea / gaztelania? & 18 \\
Aitzinerrom / gaskoia? & 3 \\
Hizk erromantzeak? & 5 \\
Gaztelania / gaskoia? & 2 \\
Gaztelania / frantsesa? & 5 \\
\hline Guztira & 477 \\
\hline
\end{tabular}

${ }^{20}$ Euskal ondare zaharreko eratorriak sortzen dituzten hizkiak bildu ditugun 7. taulan, aipatu hizki hauek ere jaso ditugu, izarño batez markaturik beti ere.

${ }^{21}$ Arabieratik datozen hitzak (arroa, atorra...), euskarara gaztelaniaren bitartez igaro direnez (ikus Etxenike 1987: 77), mailegu erromantzetzat hartu dira. 
Eta, latinaren eta erromantzeen historia kontuan hartuz, hiru garai edota hizkuntza bereizi ditugu: latina $(<\mathrm{II})$, aitzinerromantzea (III-VIII), eta hizkuntza erromantzeak (IX<). Edozelan ere, hizkuntzalari ugarik (Etxenike 1997: 22) azaldu izan duten bezala, ez da beti erraza jakitea mailegu bat latinetik edo erromantzetik datorren. Eta guk ere, zailtasunak zailtasun saiatu garen arren, zalantza ugari izan ditugu (ikus $z a$ lantzazkoak 11. taulan).

Datuen azterketara jauzi eginez, gure ikerketaren arabera, mailegu gehienak (\%37) hizkuntza erromantzeetatik datozela da nabarmentzekoena. Hizkuntza erromantzeen artean gehienak (\%62) gaztelaniatik sartutakoak dira. Hala ere, baliteke hauetakoren batzuk aragoieratik edo nafar erromantzetik sartu izana. Gaskoitik datozenak ere badira zenbait (\%36). Honek argi erakusten du euskarak garai hartan gaskoiarekin zuela harreman estua eta frantserarekikoa modernoa dela. Hala ere, gogoratu beharra dago Leizarragak Testamentu Berria frantsesetik itzuli zuela eta, ondorioz, frantseseko hitz ugari hartu zituela (gaskoizkoez landa). Baina, euskaran sustraitu gabeko maileguak direnez gero Sarasolak Euskal Hiztegitik kanpo utzi zituen eta, hori dela-eta, ez dira gure lagin nagusian agertzen (ikus 4.1.5. atala). Bigarren kopuru altuena mailegu latindarrena da (\%22). Eta azkena aitzinerromantzeari dagozkionak (\%17). Azken emaitza hauen inguruan baieztapen kontrajarri samarrak aurki ditzakegu hizkuntzalari batzuen artean. Hara Etxenike eta, Segura eta Etxebarriaren aipu bana, hurrenez hurren:

Nadie puede negar que el contacto vasco-latino debió ser intenso: el euskera está lleno de latinismos, que muestran, además, un contacto vasco-latino temprano. (Etxenike 1997: 35)

La convivencia de los ocupantes romanos, colonos, comerciantes o legionarios, con la población indígena vasca no debió ser muy intensa. Por ello, muchas voces, consideradas como préstamos directos del latín de la época de la romanización, fueron probablemente tomadas de un latín muy tardío, ya próximo a las lenguas rómanicas o bien de estas mismas lenguas durante el proceso de su gestación. (Segura eta Etxebarria 2001: 14)

Beste alde batetik, arestian aipatu gisara, nahiz eta beste hitz askoren (112) jatorria ere erromanikoa dela jakin, ez dakigu euskarara zein garaitan sartu ziren. Eta hauek multzo handi samarra osatzen dute (\%23).

Autorekako azterketari ekinez, hasteko, datu orokorren analisian ateratako ondorioak baieztatuko ditugu: Lazarragaren ugaritasuna batetik, eta, Oihenart eta RSko urritasuna bestetik. Autore bakoitzaren maileguen ehunekoa zenbatekoa den zehatz kalkulatu ostean, batazbestekotik (\%41) nabarmen jaisten direnak bereziki Oihenart (\%27) eta $R S$ (\%19), eta, gora gehien egiten dutenak Lazarraga (\%50) eta Leizarraga (\%42) direla berretsi dugu. Testu txikiei dagokienez, Zumarragaren urritasuna (\%19) da azpimarragarriena. Datu hau interesgarria da ahozko mintzotik hurbil den testua delako. Guztiarekin ere, maiztasun absolutuak behatuz gero, bere obraren handitasuna tarteko ohikoa bihurtu den bezala, Leizarragak (316, \%42) alde handia ateratzen die besteei. Bigarrena, ordea, oraingoan Lazarraga da, eta ez beste guztietan hala den Oihenart.

Begirada autoreetatik altxatu eta testu generoetan ipiniz gero, testu handienen artean dauden aldeak, zelanbait uler daitezkeela uste dugu. Izan ere, $R S(\% 19)$ eta 


\section{2. taula}

Euskara Arkaikoko mailegaketaren nolakotasuna testuz testu

\begin{tabular}{|l|r|r|r|r|r|r|r|r|r|r|r|r|}
\hline & RS & Zgz & Is & Zum & Etxp & Oih & Bela & Leiz & Mis & Laz & Bet & Guzt. \\
\hline -Latina & 18 & 16 & 7 & 2 & 26 & 20 & 5 & 73 & 2 & 24 & 14 & 207 \\
-Aitzinerrom. & 4 & 5 & 4 & 2 & 15 & 18 & 2 & 52 & 2 & 27 & 5 & 136 \\
-Hizk errom: & {$[6]$} & {$[10]$} & {$[9]$} & {$[1]$} & {$[30]$} & {$[30]$} & {$[0]$} & {$[108]$} & {$[6]$} & {$[56]$} & {$[2]$} & {$[258]$} \\
Gaztelania & 5 & 4 & 7 & 1 & 15 & 17 & 0 & 56 & 6 & 49 & 2 & 162 \\
Gaskoia & 1 & 5 & 2 & 0 & 15 & 12 & 0 & 49 & 0 & 7 & 0 & 91 \\
Frantsesa & 0 & 0 & 0 & 0 & 0 & 0 & 0 & 2 & 0 & 0 & 0 & 2 \\
Errom. ezb. euskalkika & 0 & 1 & 0 & 0 & 0 & 1 & 0 & 1 & 0 & 0 & 0 & 3 \\
-Zeltera & 2 & 0 & 0 & 1 & 2 & 2 & 0 & 3 & 0 & 1 & 1 & 12 \\
-Zalantzazkoak & {$[6]$} & {$[7]$} & {$[6]$} & {$[0]$} & {$[16]$} & {$[14]$} & {$[1]$} & {$[80]$} & {$[2]$} & {$[37]$} & {$[4]$} & {$[173]$} \\
Zalantza orokorra (?) & 4 & 2 & 2 & 0 & 1 & 6 & 0 & 11 & 0 & 6 & 0 & 32 \\
Lat/aitzinerrom/hizk errom & 0 & 3 & 1 & 0 & 8 & 3 & 0 & 33 & 1 & 16 & 4 & 69 \\
Lat/aitzinerrrom & 0 & 1 & 1 & 0 & 1 & 0 & 0 & 8 & 0 & 3 & 0 & 14 \\
Aitzinerrom/hizk errom & 1 & 0 & 0 & 0 & 0 & 2 & 1 & 3 & 0 & 3 & 0 & 10 \\
Aitzinerrom/gaztelania? & 1 & 1 & 1 & 0 & 3 & 2 & 0 & 15 & 1 & 4 & 0 & 28 \\
Aitzinerrom/gaskoia? & 0 & 0 & 0 & 0 & 0 & 0 & 0 & 3 & 0 & 0 & 0 & 3 \\
Hizk erromantzeak? & 0 & 0 & 0 & 0 & 1 & 0 & 0 & 4 & 0 & 2 & 0 & 7 \\
Gaztelania/gaskoia? & 0 & 0 & 1 & 0 & 0 & 1 & 0 & 0 & 0 & 1 & 0 & 3 \\
Gaztelania/fratsesa? & 0 & 0 & 0 & 0 & 2 & 0 & 0 & 3 & 0 & 2 & 0 & 7 \\
\hline Guztira (477) \%41 & 36 & 38 & 26 & $\mathbf{6}$ & $\mathbf{8 9}$ & $\mathbf{8 4}$ & $\mathbf{8}$ & 316 & 12 & 145 & 26 & 786 \\
\hline Hitzak guztira (1170) & 194 & 121 & 83 & 32 & 218 & 314 & 30 & 752 & 29 & 290 & 70 & 2.133 \\
\hline
\end{tabular}

Oihenarten (\%27) errefrau bilduma handietan mailegu gutxi dagoen bitartean, Leizarraga (\%42) eta Lazarragaren (\%50) lanetan askoz gehiago aurki daitezke. Corpuseko laugarren testu handia, alegia, Etxepareren poesia lana, errefauetatik baino prosa $^{22}$ lanetatik hurbilago kokatzen da maileguen kopuruari (\%41) dagokioenean. Beraz, posible da testu moten eta maileguen kopuruaren artean nolabaiteko erlazio bat izatea. Gainera, hemen ateratako emaitzak bat datoz Etchebarneren (2006) ondorioekin. Hain zuzen, obra literarioetan eguneroko hizkuntzan baino mailegu gehiago erabiltzen dela esaten du eta, gure corpusean ere, eguneroko hizkuntza horretatik hurbil dauden errefrauetan zein Zumarragaren gutunean maileguak Lazarraga eta Leizarragaren literatur obretan baino askoz gutxiago dira.

Segidan, azterketa xeheagoa egin eta aipatzeko moduko ondoko ondorioak atera ditugu:

- Lazarragak mailegu latindar gutxi ditu (24), aitzinerromantzekoak (27) baino gutxiago, eta, gaztelaniatikakoak (49) ugari (kronologikoki oso berantiarra da, ia XVII. mendekoa).

— Latina hizkuntza erromantzeen gainetik dago $R S$, Zalgize, Bela eta Betolatzarenean. Betolatzaren kasuan, behintzat, hau testu motak, eta batez ere terminologia sakratua erabili beharrak azaldu dezake.

22 Mailegu kopuruaren oposaketa «errafrauak vs prosa» baino, errefrauak vs itzulpena (edo bestela, obra literario) dela dirudi; Lazarragaren kasuan esaterako prosa zatia txikia da-eta. 
- Gaztelania, gaskoia eta frantseraren banaketa, bariazio dialektalarekin nahikoa bat dator. Baina, Oihenartek gaztelaniatik gaskoitik baino gehiago ditu eta Zalgizek ere biak ia parean.

Orain, autore desberdinek hitz mailegatu berak errepikatzeko joera behatuko dugu. Mailegu kopuru osoaren (477) eta maileguen agerraldi guztien (786) artean dagoen tartea ikusita, gehiegi ez baina errepikapenak badirela antzeman daiteke. Eta hitzen berragertze kopurua latin eta aitzinerromantzetik datozen maileguetan da handiena. Honen arrazoia mailegu hauek modernoak baino bertakotuagoak egotea izan liteke.

\subsubsection{Maileguen eremu semantikoa}

Atal honetan gure corpuseko maileguen eremu semantikoa ikertuko dugu. Horretarako bereziki Rohlfs (1933) eta ondorengo erromanista batzuen (Etxenike 1987: 65-66; Mujika 1982: 15-17, 325-330) lana hartuko dugu oinarri. Rohlfsek, euskaran eta euskal kulturan latinak izandako eragina ikertzean, euskarak latin-erromantzeetatik hartutako maileguen eremu semantikoa sakon aztertu zuen. Bertan, hainbat eremu semantiko identifikatu eta aurkeztu zituen, betiere historia orokor zein linguistikoaz ondo horniturik.

Guk aztertu ditugun 477 hitzak ere arlo askotarikoak dira (ikus 13. taula), baina, gehientsuenak bat datoz Rohlfsek azaltzen dituenekin. Erromanista alemaniarraren lanean bai eta gurean ageri ez diren eremuak izaki mitologikoena eta eskolarekin lotutako hitzena da; baina, ezberdintasun edo gabezia hau gure corpusa «A» eta «B» letretara mugatzearen ondorio izan daiteke, berak arlo batean zein bestean ematen dituen adibideetatik (lamina, eskola, liburu...) bat ere ez baita alfabetoko lehen letra bi hauekin hasten. Gurean ere badira Rohlfsek berariaz azaltzen ez dituen eremu zenbait; hala nola, neurri edo kopuru adierazleak (braza, berga...) edota nolakotasuna adierazten duten berben (abil, begira...) arloak. Eta, beste alde batetik, aditzak, batzuk arloren batean (alabatu, bataiatu... elizarenean edo bakatu merkataritzarenean esaterako) biltzeko aukera izan arren (Rohlfsek horrela), gehienak kanpoan geratzen direnez gero, hauek guztiak aditzen ohiko sailkapen semantikoaren arabera (Vendler 1967) multzokatu eta ezaugarritzen ahalegindu gara.

Datuak sakonago aztertzeari ekinez gero, ${ }^{23}$ hasteko, nabarmentzekoa da hitz materiagabeetako batzuk biltzen dituzten kontzeptu abstraktu $(69, \% 22)$ eta nolakotasun adierazleen arloetan $(52, \% 17)$ jaso dugun uzta handia. Guztiarekin ere, hau espero izateko modukoa zen eta bestela irakurri Rohlfsen (1933: 334) ondoko hitz hauek: «El tratamiento escolástico de las cuestiones espirituales exige una terminología mucho más sutil que en ciertos casos no se puede obtener sino con la aceptación de vocablos tomados de la lengua de los colonizadores. Se muestra aquí especialmente fuerte la influencia romana en la penetración de palabras de contenido abstracto». Hurrengo, tresneria eta materialen alorra (43, \%14) azpimarratu beharra dago. Bertan, armadarekin lotutako objektu izen ugari aurki daitezke:

${ }^{23}$ Maileguen adibideen artean latinetikakoak nagusi izan arren, modernoagoak ere erakutsiko ditugu; besteak beste, balezta, birjina, ahuldu. 
arku, armadura, balezta eta abar; burdin lanketaren areagotzearekin batera sortu edo zabaldutako erraminta eta gaien izenak ere bai: aizkora, amu, altzairu...; itsasoarekin lotutakoak: aingura, barka, batel...; ehungintzarako landare izenak: arkola; musika tresnak: arrabita, atabal; eta beste zenbait objektu (arka, barril...) eta material (berilo, berun...). Esanguratsua da, beraz, lexiko eremu honetan izan zen mailegaketa. Ordea, lexiko berri honen atzean dauden elementu batzuk behintzat (adib.: goldea; ikus Caro Baroja: 1979) euskararen herrian erromatarrak etorri aurretik ere bazirela dirudien arren, adierazpen kontrajarri samarrak aurki daitezke erromanisten artean. Hara hemen, Rohlfs, Etxenike eta Mujikaren aipu bana, hurrenez hurren:

Ciertas expresiones de la lengua culturalmente más fuerte vienen aceptadas sin que haya necesidad de ello. Solamente el deseo de expresarse de una manera más fina y distinguida condena a muerte a las buenas denominaciones viejas indígenas. (Rohlfs 1933: 334)

(...) su presencia no siempre es indicadora de que no haya existido con anterioridad el objeto designado por la palabra tomada en préstamo. (Etxenike 1987: 66)

Ukipen komertzial horren bitartez gure herrian existitzen etzen zenbait produkturen izena sartuko zen, hots, euskaran oraindik deiturarik etzuena. Tanketa horretakoak dira (...) eta golde. (Mujika 1982: 16)

Oso sustraituak egon ohi diren gorputz atalen izenetan ere joera egon da hauek maileguez ordekatzeko, dela euskaran dela beste hizkuntza batzuetan ere (ikus Rohlfs 1933: 335). Gure corpusean ez da gorputz atal mailegatu ugari ageri (belaun eta berna soilik, \%1).

Aurrera jarraituz, elizarekin lotutako lexikoa ere (38, \%12) ugaria da gure hitzen artean: aingeru, arima, bekatu, birjina... Kasu honetan batez ere gure corpusaren izaerak, hots, testu nabarmenki zabalena Testamentu Berria izateak, emaitzak baldintzatu ditzakeela pentsatu badezakegu ere, kristautasunaren errotzearekin eta, honek ekarritako eskolarekin, ukaezina da lexiko eliztar asko sartu zela euskaran. Eremu honetako hitzetan batzuk latin berantiar batetik mailegatuak dirudite, eta, badira antzinagoko egitura fonetikoa duten hitz latindarrak ere. Hauekin batera (batzuk lehenago eta beste batzuk beranduago) sartutakoak izango dira seguruenik erromatarrek bai antolakuntza sozial eta ohitura berriekin (bilau, biao...; 25, \%8) eta bai komertzioaren bitartez hedatutako hitzak. Ezaguna da Ebrotik zetorren bidetik merkatari erromatarrak oso goiz hasi zirela mendialdeko euskal herritarrekin hartu-emanean. Eta horrekin batera, laborantzarekin (baba, aran; 17, \%5), abeltzaintzarekin (abere; 12, \%4), animaliekin (ahate, azeri; 12, \%4), arropekin (beztidura; 7, \%2) eta abar zerikusia duten berba ugari mailegatuko ziren, nahiz eta gure corpusean kopuruak goragoko arloetakoak baino urriagoak izan. Etxearen inguruko lexikoan ere berrikuntza handia gertatu zen; izan ere, erromatarrekin batera etxegintza modua zeharo aldatu zen eta, besteak beste, egur edo buztinezko etxolak egitetik harrizko etxeak egitera igaro ziren. Hau dela-eta, gure corpusean borta, bentana (berantiarragoa) bezalako hitzak (7, \%2) aurki ditzakegu.

Aditzen eremu semantikoaz den bezainbatean, gorago aipatu bezala, argi dago batzuk orain arteko eremu zenbaitekin zerikusi zuzena daukatela. Elizarekin lotu dai- 


\section{3. taula}

Euskara Arkaikoko maileguen eremu semantikoaren nolakotasuna

\begin{tabular}{|l|r|}
\hline \multicolumn{1}{|c|}{ Eremu semantikoa } & Kopurua \\
\hline 1. Antolakuntza sozial eta administratibo-juridikoa (aiuntamentu) & 25 \\
2. Erlijioa / Eliza (aingeru) & 38 \\
3. Kontzeptu abstraktuak (amets) & 69 \\
4. Anatomia (gorputz atalak) (belaun) & 3 \\
5. Nekazaritza / Laborantza / Fruta arbolak (baba) & 17 \\
6. Abeltzaintza (bazka) & 12 \\
7. Animaliak (atun) & 12 \\
8. Etxea / Etxegintza (bentana) & 7 \\
9. Merkataritza (ardit) & 5 \\
10. Ofizioak (abokatu) & 9 \\
11. Tresneria eta materiak (aizkora) & 43 \\
12. Arropak (atorra) & 7 \\
13. Denbora tarteak (hilabete izenak...) (abuztu) & 6 \\
14. Neurriak (edo kopuruak) (braza) & 9 \\
15. Kualitateak edo nolakotasun adierazleak (arrunt) & 52 \\
\hline Guztira 1 (1-15) & 314 \\
\hline 16. Aditz estatikoak (beilatu) & 1 \\
17. Prozesu adierazleak (apaldu) & 29 \\
18. Ekintza fisikoen adierazleak (bortxatu) & 57 \\
\hline Ekintza mentalen adierazleak & {$[43]$} \\
\hline 19. Ulermen/pentsamendu adierazleak (aditu) & 7 \\
20. Hizkuntza aditzak (aipatu) & 10 \\
21. Emozio/sentipen adierazleak (aborritu) & 12 \\
22. Borondate/debeku adierazleak (abisatu) & 14 \\
\hline Guztira 2 (16-22) & 130 \\
\hline Sailkatu gabeak & 33 \\
\hline Guztira (guztira 1 + guztira 2 + sailkatu gabeak) & \\
\hline
\end{tabular}

tezke, esaterako, adoratu, arnegatu, barkatu edota benedikatu; laborantzarekin arregatu; abeltzaintzarekin bazkatu; eta arroparen arloarekin beztitu. Baina, gehienak harremantzeko zailagoak dira, eta, horregatik hauek guztiak aditzen ohiko sailkapen semantikoaren laguntzaz (Vendler 1967) ezaugarritzea erabaki dugu. Bertan, ekintza fisikoa adierazten duten aditzen nagusitasuna (57, \%44) da azpimarragarriena: askatu, begiratu, bota... Baina, adimenarekin lotutako ekintzak adierazten dituzten aditzak ere ugari $(43, \% 33)$ direla esan beharra dago, eta, hauen artean ulermen adierazleak (akordatu, asmatu...; 7), hizkuntza aditzak (aipatu, aboatu...; 10), emozio edo sentipen adierazleak (aborritu, arranguratu...; 12), eta borondate adierazleak (absolbitu, barkatu...; 14) aurki daitezke. Aditz prozesu adierazleak (ahuldu, akitu...; 29, \%22) eta bereziki estatikoak (beilatu bakarrik) askozaz gutxiago dira. 
Beraz, laburbilduz, kultura erromatarrak euskarari tresneria, material eta teknika berrien gaineko lexikoan egindako ekarpena azpimarragarria da oso. Hala ere, euskarak elementu material berri (zein aurretik ezagunen) izen ugari hartzeaz gainera, kontzeptu abstraktuen mailegaketa naroa egin duela esan beharra dago.

Jarraian, orain arteko eremu semantikoak autoreka aztertuko ditugu. Hori baino lehen, ordea, aditzen eta gainerakoen kopuruen arteko alderaketa txiki bat egingo dugu (ikus 14. taulan guztira 2 vs guztira 1). Hain zuzen ere, testu zenbaitetan ( $R S$ 7/25, Zalgize 7/30, Isasti $1 / 23$ eta Betolatza 5/21) aipaturiko bi multzo hauen arteko aldea oso handia da, aditzak oso gutxi dira-eta. Misererea da aditzak gainerakoak (izenak, izenondoak, aditzondoak) baino gehiago (6/5) dituen bakarra.

Aditzen sailkapen semantikoaren azterketarekin hasita, aditz prozesu adierazleak eta ekintza fisiko adierazleak behatuz, Lazarragaren obran bi aditz mota hauen artean dagoen oreka (12/15) da nabarmentzekoena. Gainerako testu handietan ekintza fisiko adierazleak dira nabarmenki nagusi. Ekintza adierazten duten aditzen barruan, Lazarraga eta Etxepareren lanetan, oro har ez bezala, adimenarekin lotutako ekintza adierazleak (16 Laz, 13 Etxp) ekintza fisiko adierazleak (15 Laz, 12 Etxp) baino gehiago direla aipatu beharra dago. Ekintza mental adierazleen barruan, hizkuntza aditzetan Etxeparek (4), eta, pentsamendu zein sentipen adierazleetan Lazarragak (6) duten ugaritasuna da azpimarragarriena. Emaitza hauek lotura izan dezakete testuen tematikarekin, Lazarraga eta Etxepareren testuetan maitasun-kontuak baitira nagusi.

Gainerakoen azterketari dagokionez, hasteko, kontzeptu abstraktuen arloan Oihenarten urritasuna (12) eta Zalgize (9) eta Betolatzaren (9) ugaritasuna (ia Oihenartek beste) dira nabarmentzekoak. Nolakotasun adierazleen eremuan, proportzioan $R S k$ duen kopuru altua (8) aipa daiteke. Tresna eta materialenean, Lazarraga (15) eta Isastiren (8) ugaritasuna eta, Etxepareren urritasuna (1) islatzen dira. Elizarekin lotutako lexikoan, batetik, Leizarragaren eta gainerakoen artean dagoen alde handia da aipagarria, baina baita espero izatekoa ere. Bestetik, Betolatzaren doktrinan Lazarraga eta Etxepareren lan mardulagoetan adina ageri dira eremu honetako hitzak (9). Eta azkenik, Oihenartek arlo honetan duen hitz kopuru txikia (5) ere nabarmentzekoa da. Eremu honetako hitzen erabileran testu motak ez ezik, autore batzuen izaerak ere, Oihenart eta Lazarragaren laikotasunak alegia, eragina izan dezake. Erromatarren (eta ondorengoen) antolakuntza sozio-administratiboaren eta ohituren zabalkundearekin euskarak jasotako lexikoan ere, Leizarragaren nagusitasuna (19) eta besteekiko (bigarrenak, Lazarragak 5) duen alde nabarmena da aipagarriena. Nekazaritza edota laborantzaren eremuan, Etxepareren antzutasuna azpimarratu beharra dago. Abeltzaintza zein animalien alorretan, Oihenarten (eta agian Zalgizeren) ugaritasuna (5/6), Lazarragaren urritasuna (1/2) eta Etxepareren antzutasuna ikus daitezke. Azkenik, etxea eta arroparen inguruko lexikoan Lazarragak eta, ofizio izenetan Etxeparek, Leizarragaren nagusitasuna apurtzen dutela antzematen da.

Emaitza hauek autore edo obraka sakontzen saiatuko gara segidan:

- Leizarragaren obrak, testu mota tarteko espero izatekoa zen bezala, elizaren eta antolakuntza administratiboaren inguruko lexikoa du nabarmen (kontzeptu abstraktuekin batera), eta, objektu eta animalia izenak gutxitxo. Edozelan ere, eremu semantiko guztiak ukitzen ditu. 


\section{4. taula}

Euskara Arkaikoko maileguen eremu semantikoaren nolakotasuna testuz testu ${ }^{24}$

\begin{tabular}{|c|c|c|c|c|c|c|c|c|c|c|c|c|}
\hline $\begin{array}{c}\text { Eremu } \\
\text { semantikoa }\end{array}$ & RS & $\mathrm{Zgz}$ & Is & Zum & Etxp & Oih & Bela & Leiz & Mis & Laz & Bet & Guzt \\
\hline 1 & 1 & 2 & 1 & 0 & 3 & 4 & 0 & 19 & 0 & 5 & 0 & 35 \\
\hline 2 & 1 & 2 & 3 & 1 & 9 & 5 & 1 & 33 & 1 & 9 & 9 & 74 \\
\hline 3 & 3 & 9 & 2 & 2 & 23 & 12 & 3 & 48 & 3 & 29 & 9 & 143 \\
\hline 4 & 2 & 1 & 0 & 0 & 0 & 1 & 1 & 2 & 0 & 1 & 0 & 8 \\
\hline 5 & 1 & 2 & 0 & 0 & 0 & 3 & 0 & 11 & 0 & 5 & 0 & 22 \\
\hline 6 & 2 & 2 & 0 & 0 & 0 & 5 & 0 & 8 & 0 & 1 & 0 & 18 \\
\hline 7 & 2 & 4 & 1 & 0 & 0 & 6 & 0 & 5 & 0 & 2 & 0 & 20 \\
\hline 8 & 1 & 1 & 0 & 0 & 0 & 0 & 0 & 3 & 0 & 3 & 0 & 8 \\
\hline 9 & 1 & 0 & 1 & 0 & 0 & 1 & 0 & 4 & 0 & 0 & 0 & 7 \\
\hline 10 & 0 & 2 & 1 & 0 & 4 & 3 & 0 & 3 & 0 & 2 & 0 & 15 \\
\hline 11 & 1 & 0 & 8 & 0 & 1 & 5 & 0 & 21 & 0 & 15 & 0 & 51 \\
\hline 12 & 1 & 2 & 1 & 0 & 1 & 0 & 0 & 4 & 0 & 4 & 0 & 13 \\
\hline 13 & 1 & 0 & 0 & 0 & 0 & 1 & 0 & 3 & 0 & 1 & 0 & 6 \\
\hline 14 & 0 & 0 & 1 & 0 & 2 & 2 & 0 & 5 & 0 & 1 & 0 & 11 \\
\hline 15 & 8 & 3 & 4 & 1 & 12 & 10 & 0 & 34 & 1 & 14 & 3 & 90 \\
\hline Guztira 1 & 25 & 30 & 23 & 4 & 55 & 58 & 5 & 203 & 5 & 92 & 21 & 521 \\
\hline 16 & 0 & 0 & 0 & 0 & 0 & 0 & 0 & 1 & 0 & 0 & 0 & 1 \\
\hline 17 & 2 & 2 & 0 & 0 & 4 & 4 & 1 & 16 & 4 & 12 & 0 & 45 \\
\hline 18 & 3 & 3 & 1 & 0 & 12 & 12 & 1 & 43 & 2 & 15 & 1 & 93 \\
\hline$(19,20,21,22)$ & {$[2]$} & {$[2]$} & {$[0]$} & {$[1]$} & {$[13]$} & {$[6]$} & {$[0]$} & [34] & {$[0]$} & {$[16]$} & {$[4]$} & \\
\hline 19 & 0 & 0 & 0 & 0 & 1 & 1 & 0 & 5 & 0 & 4 & 0 & 11 \\
\hline 20 & 1 & 1 & 0 & 0 & 4 & 1 & 0 & 8 & 0 & 1 & 1 & 17 \\
\hline 21 & 0 & 1 & 0 & 1 & 3 & 3 & 0 & 8 & 0 & 6 & 1 & 23 \\
\hline 22 & 1 & 0 & 0 & 0 & 5 & 1 & 0 & 13 & 0 & 5 & 2 & 27 \\
\hline Guztira 2 & 7 & 7 & 1 & 1 & 29 & 22 & 2 & 94 & 6 & 43 & 5 & 217 \\
\hline Sailk. gabeak & 4 & 1 & 2 & 1 & 5 & 4 & 1 & 19 & 1 & 10 & 0 & 48 \\
\hline Guztira & 36 & 38 & 26 & 6 & 89 & 84 & 8 & 316 & 12 & 145 & 26 & 786 \\
\hline Hitzak guzt. & 194 & 121 & 83 & 32 & 218 & 314 & 30 & 752 & 29 & 290 & 70 & 2.133 \\
\hline
\end{tabular}

— Lazarragaren lexiko mailegatuan oreka da nagusi, eremu semantiko ia guztietatik baitu apur bat. Zerbait azpimarratzekotan, tresneria nahikotxo eta abeltzaintza zein animaliekin lotutako hitz gutxi du.

- Etxeparerenean tresneria arloan duen urritasuna eta laborantza, abeltzaintza zein animalien alorretan (eta beste askotan) duen antzutasuna dira nabarmen-

${ }^{24}$ Eremu semantikoaren zutabean zenbaki bakoitzak adierazten duen arloa ezagutzeko ikus 13. taula. 
tzekoak (kontzeptu abstraktuak ditu gehienak). Hau ere ez da harritzekoa, amodioa, erlijioa eta euskararen gaiak nagusi diren bere olerkietan.

- Oihenartek hemen jasotako eremu semantiko ia guztietako hitzak ditu eta, abeltzaintza eta animaliekin lotutako hitzak ditu nabarmen. Beharbada, lehenago aipatu gisara, elizarekin lotutako lexikoa eta kontzeptu abstraktuak ditu gutxi, baina, maileguak ditu oro har urri.

- Zalgizeren errefrauetan kontzeptu abstraktu eta animalia izen nahikotxo ageri da eta, ostera, tresneria izenik batere ez.

- RSn kualitate edo nolakotasun adierazleen nagusitasuna antzeman daiteke.

- Isastirenean tresna eta material izen ugaritasuna nabarmena da.

- Betolatzak eremu semantiko oso gutxitako hitzak ditu. Guztiak dira elizarekin lotutakoak edota kontzeptu abstraktuak. Hala ere, testu mota kontuan hartuta espero izatekoa zen.

- Gainerako testu txikietan, euren urritasunean, elizarekin lotutakoak baino gehiago dira abstraktuak.

Beraz, zentzuzkoa den bezala, testuetan ageri diren eremu semantikoak darabilten gaien araberakoak dira, oro har. Horren erakusle da, esaterako, Leizarragaren Testamentu Berrian, Misererean zein Betolatzaren doktrinan ageri den lexiko eliztar andana. Baina, testuak generoka edo bereiziz gero ere, hau da, errefrauak alde batetik eta gainerakoak bestetik behatuz gero ere, oposaketa interesgarriak aurki daitezke: batetik, abeltzaintza eta animalien arloetan, $R S$, Zalgize eta Oihenarten errefrauak batuta (21) Etxepare, Leizarraga eta Lazarraga hirukoteak (16) baino hitz gehiago dituzte. Eta kontzeptu abstraktuen eremuan, ordea, errefrau biltzaileen taldeak (24) prosa-poesia egileen hirukoteak (100) baino askozaz gutxiago.

\subsubsection{Sarasolak Euskal Hiztegitik kanpo utzitakoa}

Corpusaren izaera eta osaketa azaltzean aipatu dugun legez, autore jakin batzuen $\left(R S\right.$, Zalgize, Etxepare, Oihenart, Leizarraga ${ }^{25}$ eta Betolatzaren) gaineko lexikoien eta testu zenbaiten (Isasti, Zumarraga, Bela, Misererea eta bereziki Lazarragaren) zuzeneko hustuketaren bitartez Sarasolak Euskal Hiztegitik (EH) kanpo utzitako hainbat hitz aurkitu eta jaso dugu. Baina, testu guztien hustuketa zuzena egin barik, zeharkako bide hauen bitartez testu guztietako hitz guztiak (bereziki Leizarragarenak) aurkitzeko zailtasunaz ohartuta, analisi nagusirako corpusean EHn ageri diren hitzak bakarrik barne bildu ditugu. Hori dela-eta, atal honetan Sarasolaren galbahea igaro ez duten hitz horiek ere behatu eta neurtzen saiatuko gara. Horrela, testuen benetako izaera hobeto ezagutzeko aukera izan dugu.

Analisiari ekin eta bildutako hitzen kopurua eta nolakotasuna behatuz gero (ikus 15. taula), oro har, emaitzak analisi nagusian ateratakoekin nahikoa bat datozela eta bertan ateratako ondorio behinenak berresten direla uste dugu. Izan ere, EHtik kanpo geratutako Oihenarten eta $R S k$ hitz gehienak, analisi nagusian bezalatsu, euskararen ondare zaharrekoak (edo bertatik eratorritakoak) dira eta, ez da mailegu ko-

25 Gogoratu Arestik Leizarragaren inguruan egindakoa ez dela lan lexikografiko bat, bestelako helburuak tarteko egindako hitz-zerrenda bat baizik. 


\section{5. taula}

Euskal Hiztegitik kanpo geratutako Euskara Arkaikoko lexikoaren nolakotasuna testuz testu

\begin{tabular}{|c|c|c|c|c|c|c|c|c|c|c|c|c|}
\hline & RS & $\mathrm{Zgz}$ & Is & $\mathrm{Zm}$ & Etxp & Oih & Bela & Leiz & Mis & Laz & Bet & Guzt \\
\hline Ondare zaharreko hitzak & 14 & 4 & 0 & 0 & 1 & 9 & 0 & 59 & 0 & 9 & 1 & 97 \\
\hline Bakunak & 5 & 1 & 0 & 0 & 1 & 1 & 0 & 1 & 0 & 3 & 0 & 12 \\
\hline Eratorriak & $5[1]$ & 1 & 0 & 0 & 0 & 7 [3] & 0 & $24[19]$ & 0 & 3 [1] & 0 & 40 \\
\hline Konposatuak & 4 & 2 & 0 & 0 & 0 & 1 & 0 & 34 [19] & 0 & $3[1]$ & 1 & 45 \\
\hline Maileguak & 5 & 1 & 0 & 3 & 5 & 5 & 0 & 88 & 2 & 31 & 4 & 144 \\
\hline Zalantzazkoak & 1 & 2 & 0 & 0 & 0 & 2 & 0 & 4 & 0 & 1 & 0 & 10 \\
\hline Kanpoan & 20 & 7 & 0 & 3 & 6 & 16 & 0 & 151 & 2 & 41 & 5 & 25 \\
\hline Guztira & $\% 10$ & $\% 6$ & 0 & $\% 9$ & $\% 3$ & $\% 5$ & & $\% 20$ & $\% 7$ & $\% 14$ & $\% 7$ & \\
\hline Hitzak guztira & 194 & 121 & 83 & 32 & 218 & 314 & 30 & 752 & 29 & 290 & 70 & 2.133 \\
\hline
\end{tabular}

puru alturik ageri. Oihenarten hitzen artean honako hauek aurki daitezke, esate baterako: andrekari, arsto-kume, asturutsu, barhan, berezen, borhosta (mailegua), buruti... Aldiz, RSn beste honako hauek: altamia (mailegua), andrandi, azterri, balzki, basoi, betse, burrustu. Seguruenik, hauetako asko hapaxak direlako utziko zituen Sarasolak bere hiztegitik kanpo.

Lazarragari dagokionean, hemengo datuek bere testuko maileguen nagusitasuna berresten dute. Maileguak dira berba gehienak: abisadu, akompañadu, adarga, amoremin (konposatua), artzoi, besatu, biguela eta abar. Esan bezala, beraz, hemengo uztak Lazarragaren maileguen inguruan aurrez azaldutakoa indartzen du eta, Gómez (2011: 246) ere ildo beretik mintzo da: «Como era de esperar en un texto vasco de la época, los préstamos tomados del castellano son muy abundantes en el manuscrito Lazarraga». EHa osatu zenean Lazarragaren eskuizkribua ez zen ezagutzen, baina hala ere, hiztegian bertan ageri ez diren mailegu hauek izaera modernoa dutela uste dugu, alegia, gaztelaniatik hartu eta euskaran sustraitu gabeko maileguak direla. Hitz hauetako batzuk behintzat, tradizio txikikoak izatearen zergatia lotuta egon daiteke, agian, euren eremu semantikoarekin. Hain zuzen, hitz zenbaiten eremu semantikoak (musika, hizkuntza adeitsua...) ez dira batere ohikoak Lazarragaren garaiko euskal testuetan (ikus Gómez 2011: 248-252).

Guztiarekin ere, bada aipamen eta azterketa berezia eskatzen duen daturik, Leizarragarenak, hain zuzen ere. Izan ere, analisi nagusian ez bezala (\%42), hemen bere maileguen nagusitasuna azpimarragarria da oso (\%58). Maileguak euskal ondare zaharrekoak (\%39) baino gehiago dira; esate baterako, abantzamendu, akablatu, alogeatu, ametiste, artxer, banketatu, benigno eta abar. Eta, eratorrietan ere oinarria mailegatua duten hitzak dira hamarretik zortzi: abundoski, apazegagarri, ausartgo, aprobaerazi eta abar. Honezaz gain, konposatuen artean elementu bietako bat mailegua daukatenak dira erdia baino gehiago; esate baterako: adin-flore, afekzione-gehiendun, bake-ezarle, eta bide-kantoin. Hau horrela, esan beharra dago EHtik kanpo geratutakoak kontuan hartuz gero, analisi nagusian antzemandako mailegu kopurua (316, \%42) nabarmen areagotzen dela (404, \%45). Honekin batera, konposatuen kopurua nabarmen hasten da $(50>84)$; eta ostera, ondare zaharreko bakunen ehunekoak behera egiten du. 
16. taula

Leizarragaren lexikoaren nolakotasuna

\begin{tabular}{|l|c|c|c|c|}
\hline & $\begin{array}{c}\text { Leizarragak } \\
\text { EHan }\end{array}$ & $\begin{array}{c}\text { Leizarragak } \text { EHtik } \\
\text { kanpo }\end{array}$ & $\begin{array}{c}\text { Leizarragak } \\
\text { guztira }\end{array}$ & $\begin{array}{c}\boldsymbol{E H a n} \\
\text { guztira }\end{array}$ \\
\hline Ondare zaharrekoak & $431(\% 57)$ & $59(\% 39)$ & $490(\% 54)$ & $678(\% 58)$ \\
Bakunak & $275(\% 37)$ & $1(\% 1)$ & $\mathbf{2 7 6}(\% 24)$ & $430(\% 37)$ \\
Eratorriak & $106(\% 14)$ & $24(\% 16)$ & $\mathbf{1 3 0}(\% 21)$ & $157(\% 13)$ \\
Konposatuak & $50(\% 7)$ & $34(\% 23)$ & $\mathbf{8 4}(\% 9)$ & $91(\% 8)$ \\
Maileguak & $316(\% 42)$ & $88(\% 58)$ & $\mathbf{4 0 4 ( \% 4 5 )}$ & $477(\% 41)$ \\
Zalantzazkoak & $5(\% 1)$ & $4(\% 3)$ & $\mathbf{9}(\% 2)$ & $15(\% 1)$ \\
\hline Guztira & 752 & $\mathbf{1 5 1}$ & $\mathbf{9 0 3}$ & $\mathbf{1 1 7 0}$ \\
\hline
\end{tabular}

Sarasolak EHtik kanpo utzitako maileguen nolakotasuna behatuz gero, hauetako asko frantsesetik hartutakoak direla oso nabaria da. Besteak beste, ametiste, antekrist, aparent, artxer, ardent, arrogant, aumentazione, automme, eta boga dira frantsesetikako maileguetako batzuk. Leizarragaren Testamentu Berria frantseseko bertsio batetik itzulia izanik (Salaberri 2010, Lakarra \& Mounole 2014), mailegu frantsesen ugaritasuna espero izatekoa zen. Eta, hitz hauek EHtik kanpo geratzea ere ez da harritzekoa, mailegu moderno sustraitu gabeak baitira.

Eta bukatzeko, emaitza orokorretako kopuruetan ere, EHan aurkitu ez ditugun hitz hauek kontuan hartzeak badauka eragin apur bat (ikus 17. taula). Izan ere, horrela, nagusi izaten jarraitzen duten ondare zaharreko hitzen $(\% 58>55)$ eta maileguen $(\% 41>44)$ arteko aldea txikitu egiten da. Hala ere, aldaketa hau bi autorek soilik baldintzatzen dutela esan beharra dago, alegia, Leizarraga eta Lazarragak.

Azken-azkenik, hemengo datuek 4.1.1. atalean sortutako zalantza txiki bat zelanbait argitzen lagun dezakete. Bertan, obren tamainari dagokionez, Oihenart (314; \%27) Lazarraga (290; \%25) baino gehiago izateak apur bat harritu gaituela azaldu dugu. Baina, horren arrazoietako bat Lazarragak EHtik kanpo geratutako mailegu ugari edukitzea izan zitekeela aipatu dugu. Eta, hemengo datu hauek, neurri batean behintzat, guk aurrez susmatutakoa baieztatzen dute, hitz guztiak batuta Oihenartek (330) baino hitz bat gehiago baitu Lazarragak (331).

\section{7. taula}

Euskara Arkaikoko hitzen nolakotasuna (EHtik kanpo geratutakoa kontuan hartuta)

\begin{tabular}{|l|c|c|c|}
\hline & EHan & EHtik kanpo & Guztira \\
\hline Ondare zaharrekoak & $678(\% 58)$ & $97(\% 39)$ & $775(\% 55)$ \\
Bakunak & $430(\% 37)$ & $12(\% 5)$ & $\mathbf{4 4 2}(\% 31)$ \\
Eratorriak & $157(\% 13)$ & $40(\% 16)$ & $\mathbf{1 9 7}(\% 14)$ \\
Konposatuak & $91(\% 8)$ & $45(\% 18)$ & $\mathbf{1 3 6}(\% 10)$ \\
Maileguak & $477(\% 41)$ & $144(\% 57)$ & $\mathbf{6 2 1}(\% 44)$ \\
Zalantzazkoak & $15(\% 1)$ & $10(\% 4)$ & $\mathbf{2 5}(\% 2)$ \\
\hline Guztira & $\mathbf{1 . 1 7 0}$ & $\mathbf{2 5 1}$ & $\mathbf{1 . 4 2 1}$ \\
\hline
\end{tabular}




\subsection{Azterketaren emaitzak testuz testu}

Atal honetan analisian zehar ateratako emaitzak autore edo obraka bilduko ditugu. Horrela, obra bakoitzari dagokiona argiago ikusi ahal izango dugu. Bertan, emaitza esanguratsuenak azaltzeaz gainera, testu bakoitzaren datu guztiak jasotzen dituen fitxa bana erakutsiko dugu 18-28. tauletan.

\subsubsection{Refranes y Sentencias}

Errefrau bilduma honetan, ondare zaharreko hitzen nagusitasuna (152, \%78) da azpimarratzekoena. Hitz hauen artean bakunen ugaritasuna (128, \%66) da nabarmen. Eta, konposatuen urritasuna $(7, \% 4)$ ere agerikoa da. Datu hauetan hainbat faktorek eduki lezake eragina. Batetik, $R S$ corpuseko testu arkaikoena izanik, bere konposatuen urritasuna konposatu zaharragoen presentziarekin uler liteke. Posible da bertan deribazio fase zaharra islatu eta, ondare zaharreko hitz soil luze zenbait (hiru silabakoak nahikotxo ditu) lehenagoko konplexuak izatea. Bestetik, mailegu kopuru txikia (36, \%19) testuaren generoarekin egon liteke lotuta; izan ere, mailegu kopuruari dagokionean errefrauen ( $R S$ eta Oihenart) eta gainerakoen (Leizarraga eta Lazarraga) artean dagoen oposaketa argia da.

Beste emaitza zehatzago batzuk behatuz, lehenik, maileguen artean latina hizkuntza erromantzeen gainetik dago. Bigarrenik, mailegu hauen eremu semantikoen artean, kualitate edo nolakotasun adierazleen nagusitasuna antzeman daiteke.

Bukatzeko, EHtik kanpo geratutako RSko hitz gehienak, analisi nagusian bezalatsu, euskal ondare zaharrekoak dira eta ez da mailegu askorik aurkitzen.

\subsubsection{Zalgize}

Zuberotar honen errefrauetan euskal ondare zaharreko hitzak (80, \%66) dira nabarmenki nagusi. Nagusitasun hau bakunen kopuru altuaren $(69, \% 57)$ ondorio da. Ostera, oso gutxi dira bai eratorriak $(7, \% 6)$ eta bai konposatuak $(4, \% 3)$. RSren kasuan bezala, ondare zaharreko hitz soil eta konplexuen arteko aldea, agian, errefrauotako hizkeraren arkaikotasunak azal lezake.

Emaitza xeheagoak behatuz, maileguen artean, latinetikakoak dira gehienak. Mailegu erromantzeen artean, gaztelaniatik gaskoitik adina du (Oihenartek ere gaztelaniatikakoak nagusi). Maileguen eremu semantikoari dagokionez, kontzeptu abstraktu eta animalia izen nahikotxo ageri da eta, aldiz, tresneria izenik batere ez.

\subsubsection{Isasti}

Errefrau bilduma honetan euskal ondare zaharreko hitzak dira nagusi (55, \%66). Bakunak (36, \%43) ez ezik eratorriak (7, \%8) eta bereziki konposatuak ere (12, \%14) nahikotxo (gainerako testuekin alderatuz asko) ditu. Isastiren konposatuetatik erdiak mugakizun bereziko mendekotasunezkoak dira, baina, gainerako sei konposatuak bost mota desberdinetakoak. Maileguen arlo semantikoen artean, tresna eta material izen ugaritasuna da nabarmena. 


\subsubsection{Zumarraga}

Autore honen testu laburreko ( $A$ » eta «B» letrez hasitako) 32 hitzetatik datu oso esanguratsurik ateratzea gaitza da. Edozelan ere, ondare zaharreko hitzak dira nagusi $(26, \% 81)$. Bakunak dira ia guztiak $(25, \% 78)$, ez baitago konposaturik eta eratorria bakarra. Maileguen kopurua ere oso urria da (6, \%19). Guztiarekin ere, testu motak (familiarteko bati bidalitako gutuna) hitz konplexuen zein mailegatuen urritasuna azal lezake.

\subsubsection{Etxepare}

Baxenabartarraren olerkietan ondare zaharreko hitzak dira nagusi (128, \%59). Baina, maileguak ere $(89, \% 41)$ ugari ditu. Ondare zaharrekoen artean, eratorriak (10, \%5) baino konposatu gehiago (19, \%9) baliatzea da aipagarriena. Beharbada, bere lexiko soila dela-eta joko zuten bere ondorengoek (tartean Oihenartek) poetatzat baino bertsogile kaskartzat (Salaberri 2002: 48). Maileguen eremu semantikoaz den bezainbatean, tresneria arloan duen urritasuna eta laborantza, abeltzaintza zein animalien alorretan (eta beste askotan) duen antzutasuna dira nabarmentzekoak (kontzeptu abstraktuak ditu gehienak). Hala ere, hau ez da harritzekoa, amodioa, erlijioa eta euskararen gaiak nagusi direnez bere poesian.

\subsubsection{Oihenart}

Mauletar polifazetikoaren errefrauetan ondare zaharreko hitzen ugaritasuna (225, \%72) eta maileguen urritasuna $(84, \% 27)$ dira zinez nabarmentzekoenak. Ondare zaharrekoen artean bakunak asko $(166, \% 53)$ izan arren, eratorriak ere (34, \%11) nahikotxo ditu (asko Etxepare eta Lazarragarekin alderatuz), eta, konposatuak neurrian $(25, \% 8)$. Emaitza hauetan, $R S$ ren atalean azaldu legez, lexiko honen nolakotasunak (ondare zaharrekoa ugari eta mailegatua urri izateak) zerikusi zuzena izan dezake testu generoarekin.

Eratorpen hizkien artean, hizki mailegatu gutxi du; aldiz, hainbat hizkiren $(-k i z u n,-k o r,-r o,-t i \ldots)$ erabilera esanguratsua. Mailegu erromantzeen artean, gehiago du gaztelaniatik gaskoitik baino (Zalgizek ere biak parean). Eta, maileguen eremu semantikoari dagokionez, Oihenartek lan honetan jasotako eremu semantiko ia guztietako hitzak ditu eta, abeltzaintza eta animaliekin lotutako hitzak ditu nabarmen. Beharbada, lehenago aipatu gisara, elizarekin lotutako lexikoa eta kontzeptu abstraktuak ditu gutxi, baina, maileguak ditu oro har urri. Azkenik, EHtik kanpo geratutako bere hitz gehienak, analisi nagusian bezalatsu, euskararen ondare zaharrekoak dira eta, ez da mailegu kopuru alturik ageri.

\subsubsection{Bela}

Zuberotar honen errefrau bilduma xumetik lexikoaren inguruko ondorio adierazgarririk ateratzea ez da erraza. Hala ere, euskal ondare zaharrekoak (21, \%70) dira nabarmenki nagusi; bakunak ia guztiak $(19, \% 63)$, eratorriak eta konposatuak bana baino ez. Maileguak ere, beraz, ez dira asko (8, \%27). Belaren lexikoaren nola- 
kotasunak antza handia dauka Zalgizerenarekin, nahiz eta lehenengoak eratorri gutxiago izan.

\subsubsection{Leizarraga}

Beraskoitzekoak euskal ondare zaharreko hitz bakunak (275, \%37), gainerako autoreen ehunekoekin alderatuz (\%43tik gora), urri dituela da nabarmentzekoena. Beraz, ondare zaharreko berbak nagusi $(431, \% 57)$ baditu ere ugari ditu eratorriak $(106, \% 14)$ eta maileguak $(316, \% 42)$ ere. Analisian zehar azaldu dugun legez, hitz konplexuen (eratorrien) ugaritasunak testu motarekin dauka lotura zuzena. Izan ere, Testamentu Berria itzultzeko ezinbestean erabili behar izan zuen euskara jaso eta kultua eta, Salaberrik (2002: 60) dioen bezala, «berebiziko formalizazio eta zehaztapenetaraino eraman zuen ordura arte hainbat autorek basatiegitzat agertua zuten hizkuntza». Hau horrela, corpus honetako hainbat hizki (-arazi, $-k a_{2}$, -tasun, erre-) Leizarragak bakarrik erabiltzen ditu. Eta beste hizki batzuen (-dura, $\left.-k i_{1},-z i o,-z k o\right)$ erabileran ere alde handiarekin da nagusi. Bestalde, Leizarragak lan honetarako finkatutako ia mota guztietako konposatuak ditu; salbuespenak: Izaera elkarteak eta Bikoiztapenak. Eta dvandva motako hitz elkartea Leizarragaren testuan bakarrik ageri da. Leizarragaren obrak, testu mota tarteko espero izatekoa zen bezala, elizaren eta antolakuntza administratiboaren inguruko lexikoa du nabarmen (kontzeptu abstraktuekin batera), eta, objektu eta animalia izenak gutxitxo.

EHtik kanpo geratutako Leizarragaren hitzak asko (151) dira. Eta, hauen artean maileguak (88) dira nabarmenki nagusi. Mailegu hauek (gehienak frantsesetikako mailegu modernoak) aintzat hartuz gero, ondare zaharreko berben eta maileguen arteko aldea nabarmen txikitzen da (ikus 4.1.5. atala).

\subsubsection{Misererea}

Testu txiki orotan legez, ez dugu hemengo 29 hitzetatik datu oso esanguratsurik jaso. Lexikoaren erdia baino gehiago $(17, \% 59)$ ondare zaharreko hitz soilak dira. Gainerakoak, berriz, hamarretik lau pasatxo, maileguak (12).

\subsubsection{Lazarraga}

Barrundiako «poetak» joera handia du mailegaketarako $(145, \% 50)$ eta txikia ondare zaharreko eratorri $(6, \% 2)$ eta konposatuak $(11, \% 4)$ erabiltzeko. Hain zuzen ere, maileguak ondare zaharrekoak (142, \%49) baino gehiago diren testu bakarra da. Gainera, Leizarragaren ostean, eratorpen hizki mailegatu gehien darabilena da. Maileguen ugaritasuna, testu generoarekin lotuta egon daiteke, prosa-poesia idazkien eta errefrau bildumen arteko aldea nabarmena baita. Maileguen artean, latindar gutxi ageri da, aitzinerromantzekoak baino gutxiago eta, gaztelaniatikakoak berriz ugari. Izan ere, elebiduna da eta asko edaten du bere garaiko gaztelaniatik. Maileguon eremu semantikoari dagokionez, oreka da nagusi, eremu semantiko ia guztietatik baitu apur bat. Zerbait azpimarratzekotan, tresneria izen nahikotxo eta abeltzaintza zein animaliekin lotutako hitz gutxi du. 
Bukatzeko, EHaren galbahea igaro ez duten Lazarragaren berbak nahikotxo (41) dira, mailegatuak gehienak (31). Beraz, EHtik kanpo geratutako hitzek ere, Lazarragaren maileguen nagusitasuna berresten dute.

\subsubsection{Betolatza}

Betolatzaren doktrinatik 70 hitz jaso dugu guztira. Horietarik gehienak euskal ondare zaharrekoak $(44, \% 63)$ ditugu, baina maileguak ere (26, \%37) nahikotxo dira. Ondare zaharrekoen artean, hitz konplexu bereziki konposatu gutxi dago; sei eratorri eta konposatu bakarra, zehazki. Doktrinak eliza katolikoaren ideiak herrira zabaltzeko helburua zuenez, espero izatekoa da batez ere herritarrek ulertzeko moduko hitz soilak erabiltzea. Maileguak, testu motak hala behartuta, latinetikakoak dira nagusi eta, semantikoki elizarekin lotutakoak edo kontzeptu abstraktuak ia guztiak. 


\section{8. taula}

\section{Refranes y Sentencias-en lexikoa}

\begin{tabular}{|c|c|c|c|c|c|c|c|c|c|c|c|}
\hline \multicolumn{9}{|c|}{ Euskal ondare zaharrekoak } & \multirow{2}{*}{\multicolumn{3}{|c|}{ Maileguak }} \\
\hline \multicolumn{2}{|c|}{ Bakunak } & \multicolumn{4}{|c|}{ Eratorriak } & \multicolumn{3}{|c|}{ Konposatuak } & & & \\
\hline Silaba bat & 5 & Hizkia & & \multicolumn{2}{|l|}{ Hizkia } & \multicolumn{2}{|c|}{ Eguzki-lore modukoak: } & & \multicolumn{2}{|l|}{ Latina } & 18 \\
\hline Bi silaba & 73 & [antza] & 0 & kunde & 0 & \multicolumn{2}{|c|}{ Behi-esne erakoak } & 0 & \multicolumn{2}{|c|}{ Aitzinerromantzea } & 4 \\
\hline Hiru silaba & 42 & arazi & 0 & kuntza & 1 & \multicolumn{2}{|c|}{ Mugakizun berezikoa } & $5[1]$ & \multicolumn{2}{|c|}{ Hizkuntza Erromantzeak: } & {$[6]$} \\
\hline Lau silaba & 7 & [ari] & {$[1]$} & le & 0 & \multicolumn{2}{|c|}{ Mugatzaile berezikoa } & 0 & \multicolumn{2}{|c|}{ Gaztelania } & 5 \\
\hline \multirow[t]{17}{*}{ Bost silaba } & 1 & dun & 2 & {$[\mathrm{men}]$} & 0 & \multicolumn{2}{|c|}{ Jarleku modukoak } & 0 & \multicolumn{2}{|c|}{ Gaskoia } & 1 \\
\hline & & [dura] & 0 & [mendu] & 0 & \multicolumn{2}{|c|}{ Dvandva elkarteak } & 0 & \multicolumn{2}{|c|}{ Frantsesa } & 0 \\
\hline & & eta & 0 & {$[\mathrm{os}(\mathrm{o})]$} & 0 & \multicolumn{2}{|c|}{ Atributu eta koordinazio elkarteak } & 0 & \multicolumn{2}{|c|}{$\begin{array}{l}\text { Hizk. Errom. } \\
\text { ezberdinak euskalkika }\end{array}$} & 0 \\
\hline & & garren & 2 & ro & 0 & \multicolumn{2}{|c|}{ Bahuvrîhi elkarteak } & 1 & \multicolumn{2}{|l|}{ Zeltera } & 2 \\
\hline & & garri & 1 & (t)ar & 0 & \multicolumn{2}{|c|}{ Izaera elkarteak } & 0 & \multicolumn{2}{|c|}{ Zalantzazkoak: } & {$[6]$} \\
\hline & & gile & 0 & tasun & 0 & \multicolumn{2}{|c|}{ Lotsagabe, Lofalta modukoak } & 0 & \multicolumn{2}{|c|}{ Zalantza orokorrak } & 4 \\
\hline & & gin & 1 & [tate] & 0 & Bikoiztap & & 0 & Lat./Aitzi & om. & 0 \\
\hline & & $\mathrm{ka}_{1}$ & $1[1]$ & $\mathrm{ti}$ & 1 & Aditz kon & & 0 & Lat./ & & 0 \\
\hline & & $\mathrm{ka}_{2}$ & 0 & tsu & 1 & Justaposiz & & 1 & Aitzinerro & rom & 1 \\
\hline & & $\mathrm{ka}_{3}$ & 0 & txo & 0 & Sailkatu g & amati & 0 & Aitzi & & 1 \\
\hline & & (k)ari & 1 & $\mathrm{tza} / \mathrm{tze}$ & 2 & & & & Aitzi & & 0 \\
\hline & & {$[$ keria $]$} & {$[1]$} & tzaile & 0 & & & & Hizk. Err & & 0 \\
\hline & & $\mathrm{ki}_{1}$ & 0 & [tzia] & 0 & & & & Gazt & & 0 \\
\hline & & $\mathrm{ki}_{2}$ & 1 & [zio] & 0 & & & & Gazt & & 0 \\
\hline & & (k)izun & 0 & (z)ko & 3 & & & & & & \\
\hline & & ko (go) & 0 & [erre-] & 0 & & & & & & \\
\hline & & (k)or & 0 & & & & & & & & \\
\hline Guztira1 & 128 & Guztira2 & & & 17 & Guztira3 & & 7 & Guztira4 & & 36 \\
\hline Guztira5 (1- & $2+3)$ & & & & & & & 152 & & & \\
\hline GUZTIRA & & $\begin{array}{l}\text { Ondare } \\
\text { harrekoak }\end{array}$ & & 52 & & ileguak & 36 & Zal & ntzakoak & 6 & 194 \\
\hline
\end{tabular}




\section{9. taula}

\section{Zalgizeren lexikoa}

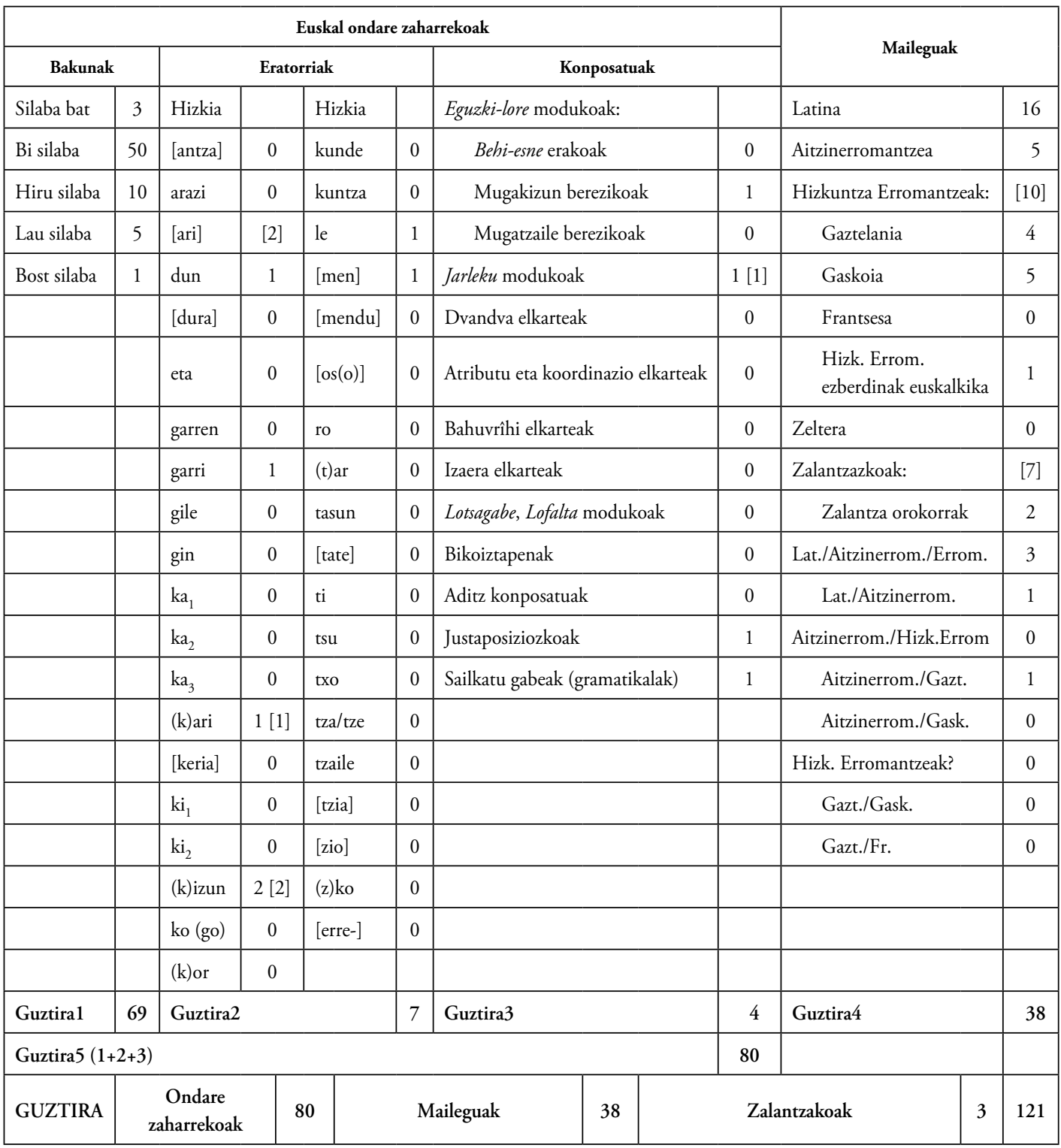




\section{0. taula}

\section{Isastiren lexikoa}

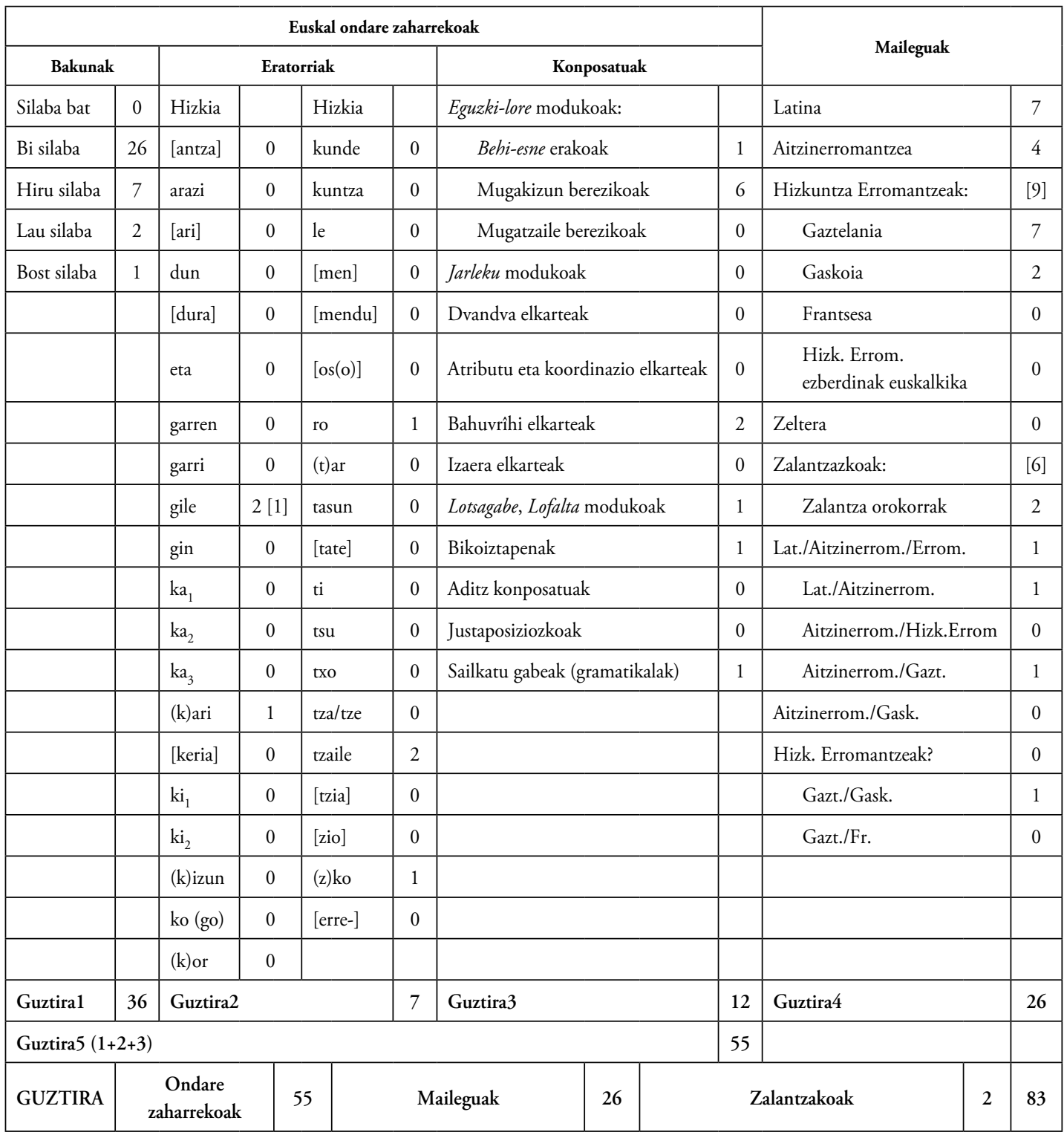




\section{1. taula}

\section{Zumarragaren lexikoa}

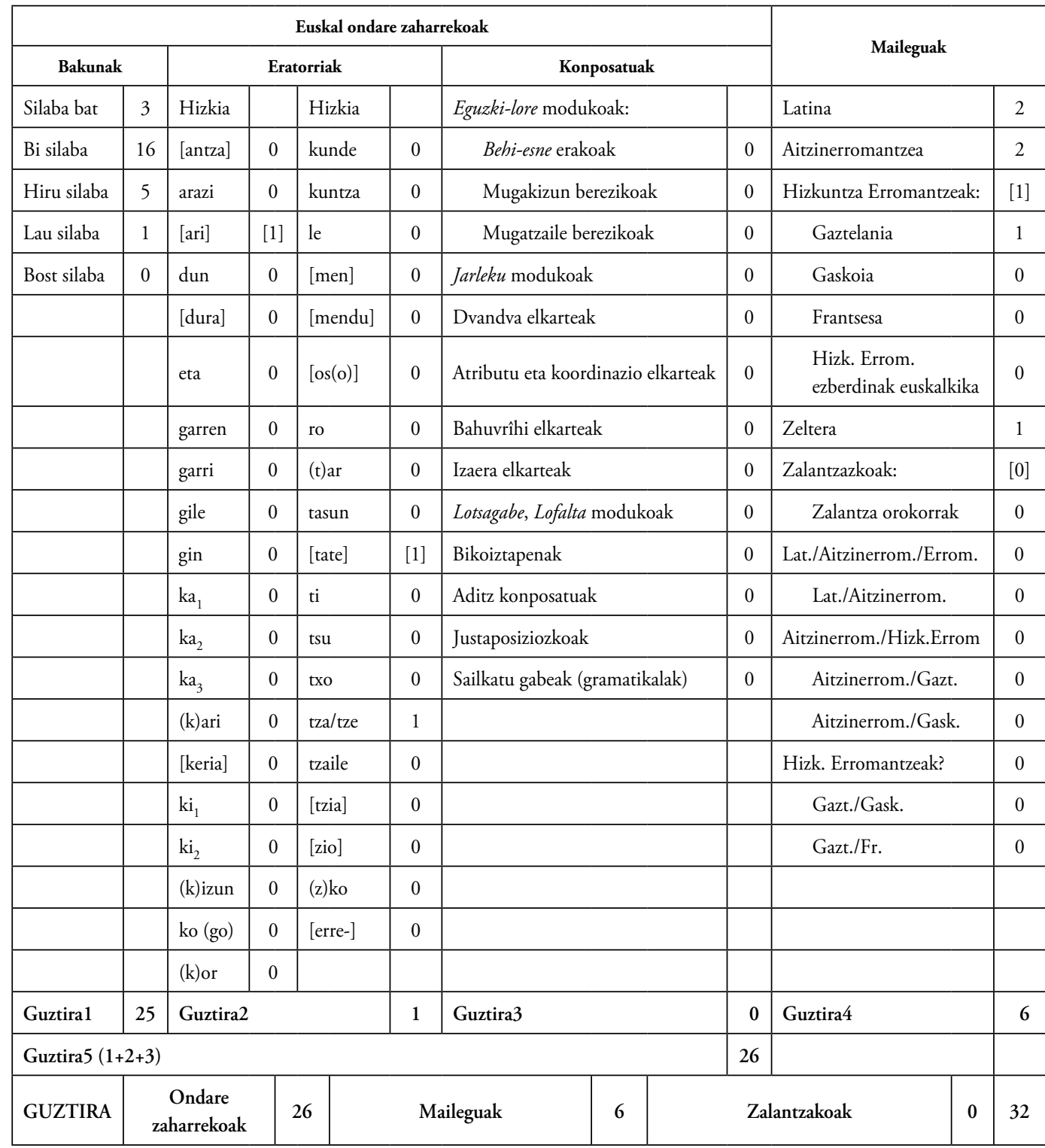




\section{2. taula}

\section{Etxepareren lexikoa}

\begin{tabular}{|c|c|c|c|c|c|c|c|c|c|c|}
\hline \multicolumn{8}{|c|}{ Euskal ondare zaharrekoak } & \multirow{2}{*}{\multicolumn{3}{|c|}{ Maileguak }} \\
\hline \multicolumn{2}{|c|}{ Bakunak } & \multicolumn{4}{|c|}{ Eratorriak } & \multicolumn{2}{|c|}{ Konposatuak } & & & \\
\hline Silaba bat & 4 & Hizkia & & \multicolumn{2}{|l|}{ Hizkia } & \multicolumn{2}{|l|}{ Eguzki-lore modukoak: } & \multicolumn{2}{|l|}{ Latina } & 26 \\
\hline Bi silaba & 68 & [antza] & 0 & kunde & 0 & Behi-esne erakoak & 0 & \multicolumn{2}{|c|}{ Aitzinerromantzea } & 15 \\
\hline Hiru silaba & 20 & arazi & 0 & kuntza & 0 & Mugakizun berezikoa & 4 & \multicolumn{2}{|c|}{ Hizkuntza Erromantzeak: } & {$[30]$} \\
\hline Lau silaba & 5 & [ari] & {$[3]$} & le & 0 & Mugatzaile berezikoa & 0 & \multicolumn{2}{|c|}{ Gaztelania } & 15 \\
\hline \multirow[t]{17}{*}{ Bost silaba } & 2 & dun & 0 & {$[\mathrm{men}]$} & [1] & Jarleku modukoak & $1[1]$ & \multicolumn{2}{|c|}{ Gaskoia } & 15 \\
\hline & & [dura] & 0 & [mendu] & {$[2]$} & Dvandva elkarteak & 0 & \multicolumn{2}{|c|}{ Frantsesa } & 0 \\
\hline & & eta & 0 & {$[\mathrm{os}(\mathrm{o})]$} & {$[2]$} & Atributu eta koordinazio elkarteak & $3[1]$ & \multicolumn{2}{|c|}{$\begin{array}{l}\text { Hizk. Errom. } \\
\text { ezberdinak euskalkika }\end{array}$} & 0 \\
\hline & & garren & 1 & ro & 0 & Bahuvrîhi elkarteak & 1 & \multicolumn{2}{|l|}{ Zeltera } & 2 \\
\hline & & garri & 0 & $(\mathrm{t}) \mathrm{ar}$ & 0 & Izaera elkarteak & 0 & Zalantzaz & & [16] \\
\hline & & gile & 0 & tasun & 0 & Lotsagabe, Lofalta modu & 2 & Zalar & & 1 \\
\hline & & gin & 0 & [tate] & {$[2]$} & Bikoiztapenak & 0 & Lat./Aitz & & 8 \\
\hline & & $\mathrm{ka}_{1}$ & 0 & $\mathrm{ti}$ & 0 & Aditz konposatuak & 1 & Lat./ & & 1 \\
\hline & & $\mathrm{ka}_{2}$ & 0 & tsu & 0 & Justaposiziozkoak & 2 & Aitzinerr & & 0 \\
\hline & & $\mathrm{ka}_{3}$ & 0 & txo & 0 & Sailkatu gabeak (gramat & 5 & Aitzir & & 3 \\
\hline & & (k)ari & $1[1]$ & $\mathrm{tza} / \mathrm{tze}$ & 1 & & & Aitzir & & 0 \\
\hline & & {$[$ keria $]$} & 0 & tzaile & 0 & & & Hizk. Er & & 1 \\
\hline & & $\mathrm{ki}_{1}$ & $4[3]$ & [tzia] & 0 & & & Gazt. & & 0 \\
\hline & & $\mathrm{ki}_{2}$ & 0 & [zio] & 0 & & & Gazt. & & 2 \\
\hline & & (k)izun & 1 & (z)ko & $2[1]$ & & & & & \\
\hline & & ko (go) & 0 & [erre-] & 0 & & & & & \\
\hline & & (k)or & 0 & & & & & & & \\
\hline Guztira1 & 99 & Guztira2 & & & 10 & Guztira3 & 19 & Guztira4 & & 89 \\
\hline Guztira5 (1- & $2+3)$ & & & & & & 128 & & & \\
\hline GUZTIRA & & $\begin{array}{l}\text { Ondare } \\
\text { aharrekoak }\end{array}$ & & 8 & & leguak & Zal & tzakoak & 1 & 218 \\
\hline
\end{tabular}




\section{3. taula}

\section{Oihenarten lexikoa}

\begin{tabular}{|c|c|c|c|c|c|c|c|c|c|c|c|}
\hline \multicolumn{9}{|c|}{ Euskal ondare zaharrekoak } & \multirow{2}{*}{\multicolumn{3}{|c|}{ Maileguak }} \\
\hline \multicolumn{2}{|c|}{ Bakunak } & \multicolumn{4}{|c|}{ Eratorriak } & \multicolumn{3}{|c|}{ Konposatuak } & & & \\
\hline Silaba bat & 6 & Hizkia & & Hizkia & & \multicolumn{2}{|c|}{ Eguzki-lore modukoak: } & & \multicolumn{2}{|l|}{ Latina } & 20 \\
\hline Bi silaba & 93 & [antza] & 0 & kunde & 0 & \multicolumn{2}{|c|}{ Behi-esne erakoak } & 3 & \multicolumn{2}{|c|}{ Aitzinerromantzea } & 18 \\
\hline Hiru silaba & 43 & arazi & 0 & kuntza & 0 & \multicolumn{2}{|c|}{ Mugakizun berezikoa } & 9 & \multicolumn{2}{|c|}{ Hizkuntza Erromantzeak: } & [30] \\
\hline Lau silaba & 22 & [ari] & {$[3]$} & le & 0 & \multicolumn{2}{|c|}{ Mugatzaile berezikoa } & 0 & \multicolumn{2}{|c|}{ Gaztelania } & 17 \\
\hline \multirow[t]{17}{*}{ Bost silaba } & 2 & dun & $2[1]$ & {$[\mathrm{men}]$} & 1 & \multicolumn{2}{|c|}{ Jarleku modukoak } & $1[1]$ & \multicolumn{2}{|c|}{ Gaskoia } & 12 \\
\hline & & [dura] & 0 & [mendu] & 0 & \multicolumn{2}{|c|}{ Dvandva elkarteak } & 0 & \multicolumn{2}{|c|}{ Frantsesa } & 0 \\
\hline & & eta & 1 & {$[\mathrm{os}(\mathrm{o})]$} & 0 & \multicolumn{2}{|c|}{ Atributu eta koordinazio elkarteak } & 0 & \multicolumn{2}{|c|}{$\begin{array}{l}\text { Hizk. Errom. } \\
\text { ezberdinak euskalkika }\end{array}$} & 1 \\
\hline & & garren & 0 & ro & 2 & \multicolumn{2}{|c|}{ Bahuvrîhi elkarteak } & 0 & \multicolumn{2}{|l|}{ Zeltera } & 2 \\
\hline & & garri & 2 & $(\mathrm{t}) \mathrm{ar}$ & 0 & Izaera ell & & $2[1]$ & Zalantzaz & & [14] \\
\hline & & gile & 1 & tasun & 0 & Lotsagab & hodul & 3 & Zalar & & 6 \\
\hline & & gin & 0 & [tate] & 0 & Bikoizta & & 0 & Lat./Aitz & om. & 3 \\
\hline & & $\mathrm{ka}_{1}$ & 0 & $\mathrm{ti}$ & $2[1]$ & Aditz ko & & 1 & Lat./ & & 0 \\
\hline & & $\mathrm{ka}_{2}$ & 0 & tsu & 3 & Justaposi & & 3 & Aitzinerr & rom & 2 \\
\hline & & $\mathrm{ka}_{3}$ & 1 & txo & 0 & Sailkatu & amati & 3 & Aitzir & & 2 \\
\hline & & (k)ari & 1 & $\mathrm{tza} / \mathrm{tze}$ & 0 & & & & Aitzir & & 0 \\
\hline & & [keria] & 1 & tzaile & $5[2]$ & & & & Hizk. Er & & 0 \\
\hline & & $\mathrm{ki}_{1}$ & $5[1]$ & [tzia] & 0 & & & & Gazt. & & 1 \\
\hline & & $\mathrm{ki}_{2}$ & 0 & [zio] & 0 & & & & Gazt. & & 0 \\
\hline & & (k)izun & $4[2]$ & (z)ko & 0 & & & & & & \\
\hline & & ko (go) & 0 & [erre-] & 0 & & & & & & \\
\hline & & (k)or & 3 & & & & & & & & \\
\hline Guztira1 & 166 & Guztira2 & & & 34 & Guztira3 & & 25 & Guztira4 & & 84 \\
\hline Guztira5 & $2+3)$ & & & & & & & 225 & & & \\
\hline GUZTIRA & & $\begin{array}{l}\text { Ondare } \\
\text { harrekoak }\end{array}$ & & 25 & & leguak & 84 & Zala & tzakoak & 5 & 314 \\
\hline
\end{tabular}




\section{4. taula}

\section{Belaren lexikoa}

\begin{tabular}{|c|c|c|c|c|c|c|c|c|c|c|c|}
\hline \multicolumn{9}{|c|}{ Euskal ondare zaharrekoak } & \multirow{2}{*}{\multicolumn{3}{|c|}{ Maileguak }} \\
\hline \multicolumn{2}{|c|}{ Bakunak } & \multicolumn{4}{|c|}{ Eratorriak } & \multicolumn{3}{|c|}{ Konposatuak } & & & \\
\hline Silaba bat & 2 & Hizkia & & Hizkia & & \multicolumn{2}{|c|}{ Eguzki-lore modukoak: } & & \multicolumn{2}{|l|}{ Latina } & 5 \\
\hline Bi silaba & 12 & [antza] & 0 & kunde & 0 & \multicolumn{2}{|c|}{ Behi-esne erakoak } & 0 & \multicolumn{2}{|c|}{ Aitzinerromantzea } & 2 \\
\hline Hiru silaba & 4 & arazi & 0 & kuntza & 0 & \multicolumn{2}{|c|}{ Mugakizun bereziko } & 0 & \multicolumn{2}{|c|}{ Hizkuntza Erromantzeak: } & [0] \\
\hline Lau silaba & 1 & [ari] & 0 & le & 0 & \multicolumn{2}{|c|}{ Mugatzaile berezikoa } & 0 & \multicolumn{2}{|c|}{ Gaztelania } & 0 \\
\hline \multirow[t]{17}{*}{ Bost silaba } & 0 & dun & 0 & {$[\mathrm{men}]$} & 0 & \multicolumn{2}{|c|}{ Jarleku modukoak } & 0 & \multicolumn{2}{|c|}{ Gaskoia } & 0 \\
\hline & & [dura] & 0 & [mendu] & 0 & \multicolumn{2}{|c|}{ Dvandva elkarteak } & 0 & \multicolumn{2}{|c|}{ Frantsesa } & 0 \\
\hline & & eta & 0 & {$[\mathrm{os}(\mathrm{o})]$} & 0 & \multicolumn{2}{|c|}{ Atributu eta koordinazio elkarteak } & 0 & \multicolumn{2}{|c|}{$\begin{array}{l}\text { Hizk. Errom. } \\
\text { ezberdinak euskalkika }\end{array}$} & 0 \\
\hline & & garren & 0 & ro & 0 & \multicolumn{2}{|c|}{ Bahuvrîhi elkarteak } & 0 & \multicolumn{2}{|l|}{ Zeltera } & 0 \\
\hline & & garri & 0 & $(\mathrm{t}) \mathrm{ar}$ & 0 & Izaera elk & & $1[1]$ & Zalantzaz & & [1] \\
\hline & & gile & 0 & tasun & 0 & Lotsagabe & lod & 0 & Zalan & & 0 \\
\hline & & gin & 0 & [tate] & [1] & Bikoiztap & & 0 & Lat./Aitzi & m. & 0 \\
\hline & & $\mathrm{ka}_{1}$ & 0 & ti & 0 & Aditz kon & & 0 & Lat./P & & 0 \\
\hline & & $\mathrm{ka}_{2}$ & 0 & tsu & 0 & Justaposiz & & 0 & Aitzinerro & om & 1 \\
\hline & & $\mathrm{ka}_{3}$ & 0 & txo & 0 & Sailkatu g & $\mathrm{ma}$ & 0 & Aitzin & & 0 \\
\hline & & (k)ari & 0 & tza/tze & 1 & & & & Aitzin & & 0 \\
\hline & & [keria] & 0 & tzaile & 0 & & & & Hizk. Err & & 0 \\
\hline & & $\mathrm{ki}_{1}$ & 0 & [tzia] & 0 & & & & Gazt. & & 0 \\
\hline & & $\mathrm{ki}_{2}$ & 0 & [zio] & 0 & & & & Gazt. & & 0 \\
\hline & & (k)izun & 0 & (z)ko & 0 & & & & & & \\
\hline & & ko (go) & 0 & [erre-] & 0 & & & & & & \\
\hline & & (k)or & 0 & & & & & & & & \\
\hline Guztiral & 19 & Guztira & & & 1 & Guztira3 & & 1 & Guztira4 & & 8 \\
\hline Guztira5 (1 & $2+3)$ & & & & & & & 21 & & & \\
\hline GUZTIRA & & $\begin{array}{l}\text { Ondare } \\
\text { larrekoak }\end{array}$ & & 21 & & ileguak & 8 & $\mathrm{Zal}$ & ntzakoak & 1 & 30 \\
\hline
\end{tabular}




\section{5. taula}

\section{Leizarragaren lexikoa}

\begin{tabular}{|c|c|c|c|c|c|c|c|c|c|c|c|}
\hline \multicolumn{9}{|c|}{ Euskal ondare zaharrekoak } & \multirow{2}{*}{\multicolumn{3}{|c|}{ Maileguak }} \\
\hline \multicolumn{2}{|c|}{ Bakunak } & \multicolumn{4}{|c|}{ Eratorriak } & \multicolumn{3}{|c|}{ Konposatuak } & & & \\
\hline Silaba bat & 9 & Hizkia & & \multicolumn{2}{|l|}{ Hizkia } & \multicolumn{2}{|c|}{ Eguzki-lore modukoak: } & & \multicolumn{2}{|l|}{ Latina } & 73 \\
\hline Bi silaba & 123 & [antza] & 1 & kunde & {$[1]$} & \multicolumn{2}{|c|}{ Behi-esne erakoak } & 4 & \multicolumn{2}{|c|}{ Aitzinerromantzea } & 52 \\
\hline Hiru silaba & 104 & arazi & $9[5]$ & kuntza & 0 & \multicolumn{2}{|c|}{ Mugakizun berezikoak } & $18[1]$ & \multicolumn{2}{|c|}{ Hizkuntza Erromantzeak: } & [108] \\
\hline Lau silaba & 32 & [ari] & {$[2]$} & le & 3 & \multicolumn{2}{|c|}{ Mugatzaile berezikoak } & 1 & \multicolumn{2}{|c|}{ Gaztelania } & 56 \\
\hline \multirow[t]{17}{*}{ Bost silaba } & 7 & dun & $2[1]$ & {$[\mathrm{men}]$} & $2[1]$ & \multicolumn{2}{|c|}{ Jarleku modukoak } & 2 & \multicolumn{2}{|c|}{ Gaskoia } & 49 \\
\hline & & [dura] & {$[3]$} & [mendu] & {$[4]$} & \multicolumn{2}{|c|}{ Dvandva elkarteak } & 1 & \multicolumn{2}{|c|}{ Frantsesa } & 2 \\
\hline & & eta & 0 & {$[\mathrm{os}(\mathrm{o})]$} & {$[4]$} & \multicolumn{2}{|c|}{ Atributu eta koordinazio elkarteak } & 1 & \multicolumn{2}{|c|}{$\begin{array}{l}\text { Hizk. Errom. } \\
\text { ezberdinak euskalkika }\end{array}$} & 1 \\
\hline & & garren & 3 & ro & 0 & \multicolumn{2}{|c|}{ Bahuvrîhi elkarteak } & 2 & \multicolumn{2}{|l|}{ Zeltera } & 3 \\
\hline & & garri & $3[1]$ & $(\mathrm{t}) \mathrm{ar}$ & 0 & \multicolumn{2}{|c|}{ Izaera elkarteak } & 0 & \multicolumn{2}{|c|}{ Zalantzazkoak: } & {$[80]$} \\
\hline & & gile & 0 & tasun & $16[3]$ & \multicolumn{2}{|c|}{ Lotsagabe, Lofalta modukoak } & $5[3]$ & \multicolumn{2}{|c|}{ Zalantza orokorrak } & 11 \\
\hline & & gin & 0 & [tate] & {$[6]$} & Bikoizta & & 0 & Lat./Aitzi & $\mathrm{m}$ & 33 \\
\hline & & $\mathrm{ka}_{1}$ & 0 & $\mathrm{ti}$ & 1 & Aditz ko & & 3 & Lat./A & & 8 \\
\hline & & $\mathrm{ka}_{2}$ & 3 & tsu & $3[2]$ & Justapos & & 7 & Aitzinerro & rom & 3 \\
\hline & & $\mathrm{ka}_{3}$ & 1 & txo & 3 & Sailkatu & amatik & 6 & Aitzin & & 15 \\
\hline & & $(\mathrm{k})$ ari & 2 & $\mathrm{tza} / \mathrm{tze}$ & 2 & & & & Aitzin & & 3 \\
\hline & & [keria] & $2[1]$ & tzaile & $11[9]$ & & & & Hizk. Err & & 4 \\
\hline & & $\mathrm{ki}_{1}$ & $14[5]$ & [tzia] & [5] & & & & Gazt. & & 0 \\
\hline & & $\mathrm{ki}_{2}$ & 1 & [zio] & {$[11]$} & & & & Gazt. & & 3 \\
\hline & & (k)izun & 1 & (z)ko & $21[5]$ & & & & & & \\
\hline & & ko (go) & 1 & [erre-] & 1 & & & & & & \\
\hline & & (k)or & 2 & & & & & & & & \\
\hline Guztira1 & 275 & Guztira & & & 106 & Guztira3 & & 50 & Guztira4 & & 316 \\
\hline Guztira5 (1 & $2+3)$ & & & & & & & 431 & & & \\
\hline GUZTIRA & & $\begin{array}{l}\text { Ondare } \\
\text { harrekoak }\end{array}$ & & & & leguak & 316 & $\mathrm{Zal}$ & ntzakoak & 5 & 752 \\
\hline
\end{tabular}




\section{6. taula}

\section{Miserere-ko lexikoa}

\begin{tabular}{|c|c|c|c|c|c|c|c|c|c|c|c|}
\hline \multicolumn{9}{|c|}{ Euskal ondare zaharrekoak } & \multirow{2}{*}{\multicolumn{3}{|c|}{ Maileguak }} \\
\hline \multicolumn{2}{|c|}{ Bakunak } & \multicolumn{4}{|c|}{ Eratorriak } & \multicolumn{3}{|c|}{ Konposatuak } & & & \\
\hline Silaba bat & 0 & Hizkia & & Hizkia & & \multicolumn{2}{|c|}{ Eguzki-lore modukoak: } & & \multicolumn{2}{|l|}{ Latina } & 2 \\
\hline Bi silaba & 14 & [antza] & 1 & kunde & 0 & \multicolumn{2}{|c|}{ Behi-esne erakoak } & 0 & \multicolumn{2}{|c|}{ Aitzinerromantzea } & 2 \\
\hline Hiru silaba & 3 & arazi & 0 & kuntza & 0 & \multicolumn{2}{|c|}{ Mugakizun berezikoa } & 0 & \multicolumn{2}{|c|}{ Hizkuntza Erromantzeak: } & [6] \\
\hline Lau silaba & 0 & [ari] & 0 & le & 0 & \multicolumn{2}{|c|}{ Mugatzaile berezikoa } & 0 & \multicolumn{2}{|c|}{ Gaztelania } & 6 \\
\hline \multirow[t]{17}{*}{ Bost silaba } & 0 & dun & 0 & {$[$ men] } & 0 & \multicolumn{2}{|c|}{ Jarleku modukoak } & 0 & \multicolumn{2}{|c|}{ Gaskoia } & 0 \\
\hline & & [dura] & 0 & [mendu] & 0 & \multicolumn{2}{|c|}{ Dvandva elkarteak } & 0 & \multicolumn{2}{|c|}{ Frantsesa } & 0 \\
\hline & & eta & 0 & {$[\mathrm{os}(\mathrm{o})]$} & 0 & \multicolumn{2}{|c|}{ Atributu eta koordinazio elkarteak } & 0 & \multicolumn{2}{|c|}{$\begin{array}{l}\text { Hizk. Errom. } \\
\text { ezberdinak euskalkika }\end{array}$} & 0 \\
\hline & & garren & 0 & ro & 0 & \multicolumn{2}{|c|}{ Bahuvrîhi elkarteak } & 0 & \multicolumn{2}{|l|}{ Zeltera } & 0 \\
\hline & & garri & 0 & (t)ar & 0 & Izaera elk & & 0 & Zalantzaz & & {$[2]$} \\
\hline & & gile & 0 & tasun & 0 & Lotsagabe & lodu & 0 & Zalan & & 0 \\
\hline & & gin & 0 & [tate] & [1] & Bikoiztap & & 0 & Lat./Aitzi & m. & 1 \\
\hline & & $\mathrm{ka}_{1}$ & 0 & $\mathrm{ti}$ & 0 & Aditz kon & & 0 & Lat./A & & 0 \\
\hline & & $\mathrm{ka}_{2}$ & 0 & tsu & 0 & Justaposiz & & 0 & Aitzinerro & om & 0 \\
\hline & & $\mathrm{ka}_{3}$ & 0 & txo & 0 & Sailkatu g & imati & 0 & Aitzin & & 1 \\
\hline & & (k)ari & 0 & $\mathrm{tza} / \mathrm{tze}$ & 0 & & & & Aitzin & & 0 \\
\hline & & [keria] & 0 & tzaile & 0 & & & & Hizk. Err & & 0 \\
\hline & & $\mathrm{ki}_{1}$ & 0 & [tzia] & 0 & & & & Gazt.I & & 0 \\
\hline & & $\mathrm{ki}_{2}$ & 0 & [zio] & 0 & & & & Gazt.I & & 0 \\
\hline & & (k)izun & 0 & (z)ko & 0 & & & & & & \\
\hline & & ko (go) & 0 & [erre-] & 0 & & & & & & \\
\hline & & (k)or & 0 & & & & & & & & \\
\hline Guztira1 & 17 & Guztira & & & 0 & Guztira3 & & 0 & Guztira4 & & 12 \\
\hline Guztira5 (1 & $2+3)$ & & & & & & & 17 & & & \\
\hline GUZTIRA & & $\begin{array}{l}\text { Ondare } \\
\text { harrekoak }\end{array}$ & & 17 & & aileguak & 12 & $\mathrm{Za}$ & antzakoak & 0 & 29 \\
\hline
\end{tabular}




\section{7. taula}

\section{Lazarragaren lexikoa}

\begin{tabular}{|c|c|c|c|c|c|c|c|c|c|c|c|}
\hline \multicolumn{9}{|c|}{ Euskal ondare zaharrekoak } & \multirow{2}{*}{\multicolumn{3}{|c|}{ Maileguak }} \\
\hline \multicolumn{2}{|c|}{ Bakunak } & \multicolumn{4}{|c|}{ Eratorriak } & \multicolumn{3}{|c|}{ Konposatuak } & & & \\
\hline Silaba bat & 6 & Hizkia & & \multicolumn{2}{|l|}{ Hizkia } & \multicolumn{3}{|c|}{ Eguzki-lore modukoak: } & \multicolumn{2}{|l|}{ Latina } & 24 \\
\hline Bi silaba & 71 & [antza] & 0 & kunde & 0 & \multicolumn{2}{|c|}{ Behi-esne erakoak } & 1 & \multicolumn{2}{|c|}{ Aitzinerromantzea } & 27 \\
\hline Hiru silaba & 35 & arazi & 0 & kuntza & 0 & \multicolumn{2}{|c|}{ Mugakizun berezikoa } & 4 & \multicolumn{2}{|c|}{ Hizkuntza Erromantzeak: } & {$[56]$} \\
\hline Lau silaba & 12 & [ari] & {$[1]$} & le & 0 & \multicolumn{2}{|c|}{ Mugatzaile berezikoal } & 1 & \multicolumn{2}{|c|}{ Gaztelania } & 49 \\
\hline \multirow[t]{17}{*}{ Bost silaba } & 1 & dun & 0 & [men] & 0 & \multicolumn{2}{|c|}{ Jarleku modukoak } & 0 & \multicolumn{2}{|c|}{ Gaskoia } & 7 \\
\hline & & [dura] & {$[1]$} & [mendu] & {$[2]$} & \multicolumn{2}{|c|}{ Dvandva elkarteak } & 0 & \multicolumn{2}{|c|}{ Frantsesa } & 0 \\
\hline & & eta & 0 & {$[\mathrm{os}(\mathrm{o})]$} & {$[2]$} & \multicolumn{2}{|c|}{ Atributu eta koordinazio elkarteak } & 1 & \multicolumn{2}{|c|}{$\begin{array}{l}\text { Hizk. Errom. } \\
\text { ezberdinak euskalkika }\end{array}$} & 0 \\
\hline & & garren & 0 & ro & 0 & \multicolumn{2}{|c|}{ Bahuvrîhi elkarteak } & 1 & \multicolumn{2}{|l|}{ Zeltera } & 1 \\
\hline & & garri & 0 & $(\mathrm{t}) \mathrm{ar}$ & 1 & Izaera ell & & 0 & Zalantzaz & & {$[37]$} \\
\hline & & gile & 0 & tasun & 0 & Lotsagab & moduk & 2 & Zalan & & 6 \\
\hline & & gin & 0 & [tate] & {$[3]$} & Bikoizta & & 0 & Lat./Aitzi & om. & 16 \\
\hline & & $\mathrm{ka}_{1}$ & 0 & $\mathrm{ti}$ & 0 & Aditz ko & & 0 & Lat./ & & 3 \\
\hline & & $\mathrm{ka}_{2}$ & 0 & tsu & 0 & Justapos & & 0 & Aitzinerrc & rom & 3 \\
\hline & & $\mathrm{ka}_{3}$ & 0 & txo & $1[1]$ & Sailkatu & ramatil & 1 & Aitzir & & 4 \\
\hline & & (k)ari & 0 & $\mathrm{tza} / \mathrm{tze}$ & 1 & & & & Aitzir & & 0 \\
\hline & & [keria $]$ & 0 & tzaile & 0 & & & & Hizk. Err & & 2 \\
\hline & & $\mathrm{ki}_{1}$ & 1 & [tzia] & {$[1]$} & & & & Gazt. & & 1 \\
\hline & & $\mathrm{ki}_{2}$ & 0 & [zio] & {$[1]$} & & & & Gazt. & & 2 \\
\hline & & (k)izun & 0 & (z)ko & 2 & & & & & & \\
\hline & & ko (go) & 0 & [erre-] & 0 & & & & & & \\
\hline & & (k)or & 0 & & & & & & & & \\
\hline Guztiral & 125 & Guztira2 & & & 6 & Guztira3 & & 11 & Guztira4 & & 145 \\
\hline Guztira5 $(1+$ & $2+3)$ & & & & & & & 142 & & & \\
\hline GUZTIRA & & $\begin{array}{l}\text { Ondare } \\
\text { larrekoak }\end{array}$ & & 42 & $\mathrm{Ma}$ & leguak & 145 & Zal & ntzakoak & 3 & 290 \\
\hline
\end{tabular}




\section{8. taula}

\section{Betolatzaren lexikoa}

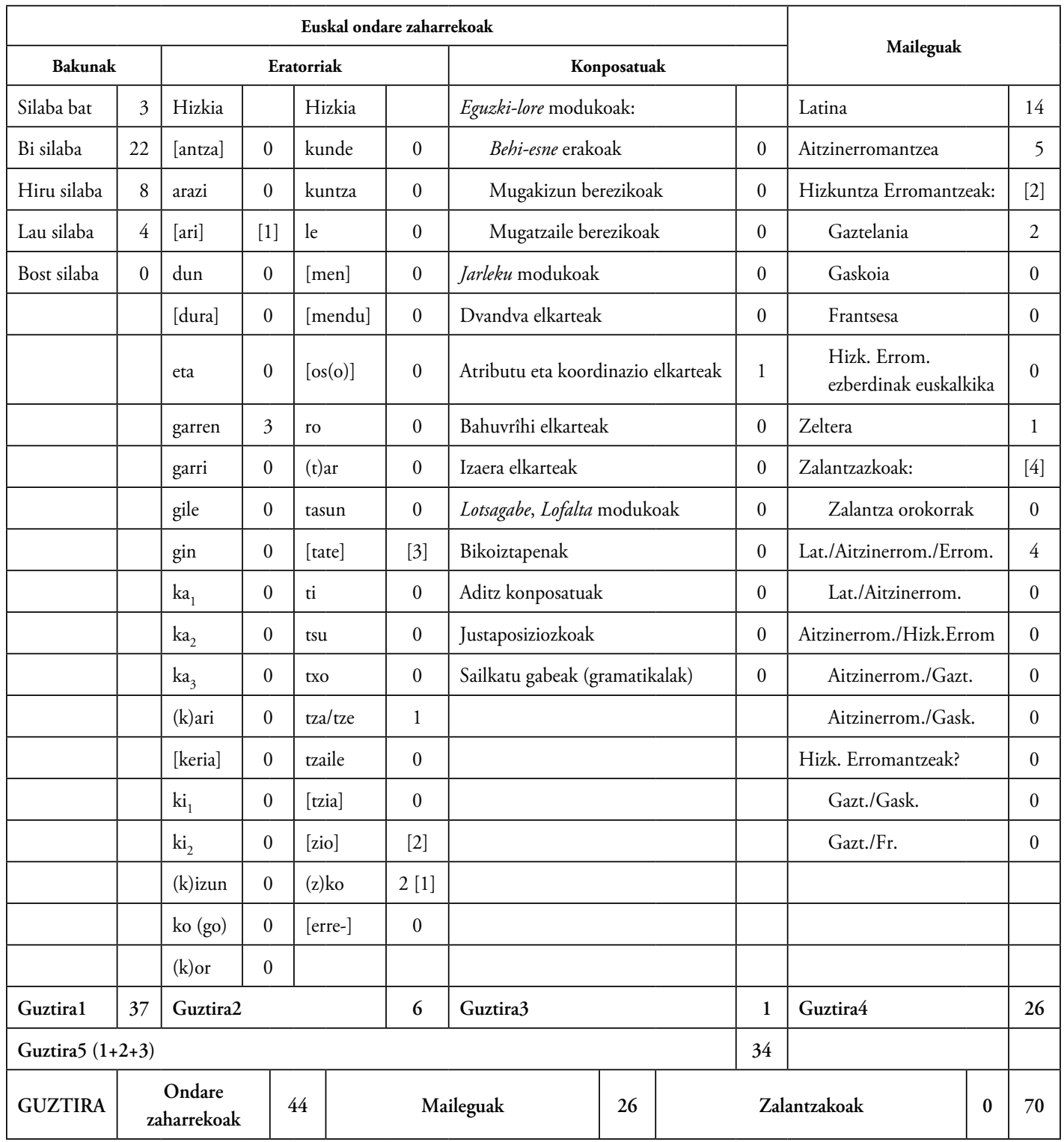




\section{Ondorioak}

Lan honetan Euskara Arkaikoko lexikoaren analisi sinkronikoa egin nahi izan dugu, ustez analisi horretatik hainbat ondorio atera ahal genituela. Hala ere, ikerketan zehar alderdi teoriko zein metodologikoarekin loturiko hainbat arazori aurre egin behar izan diogu. Hau dela-eta, azterketaren ondorio eta ekarpen nagusiak zein aurrera begirako ikerketa ildo posibleak azaldu baino lehen, eduki ditugun zailtasun bereziki metodologikoen gogoeta egiteko tartea hartuko dugu.

Lehenik eta behin, lan honetarako oinarri teoriko sendo bat osatzeko eduki ditugun zailtasunak ekarri behar ditugu gogora. Izan ere, euskaran autore jakinen lexikoiaz haragoko lan lexikologikoak oso gutxi dira eta, ondorioz, inguruko hizkuntzetako lexikoaren gaineko lanetatik (batez ere ingelesekoetatik) jaso ditugu oinarriak osatzeko zimenduak (ikus 2. atala).

Bigarrenik, corpusa osatzeko garaian izandako oztopoez jardungo dugu. Izan ere, hainbat erabaki esanguratsu hartu ditugu. Batetik, errefrau bildumak euren argitaratze urtea baino mende bat lehenagokotzat hartuz egindako testuen berrantolatze kronologikoak eragin nabarmena izan du. Hain zuzen, XV-Xvi. mendeetako testuen hurrenkera kronologikoa aldatzeaz gainera, XVII. mendean argitaratutako errefrau bilduma zenbait ere gure corpusean sartu ditugu (ikus 3.1.1. atala). Beste alde batetik, gogoratu beharra daukagu, hitzak zuzenean testuetatik bertatik jasotzeko denbora faltaz oharturik, berben bilketa lana Sarasolaren Euskal Hiztegia (2007) oinarri hartuaz egin dugula. Hau da, analisi nagusirako corpusean Euskal Hiztegian agertzen diren hitzak soilik jaso ditugu (ikus 3.1.2. atala). Hala ere, honela testu guztien benetako izaera erakustea zaila dela iritzita, autore jakin batzuen gaineko lexikoiak eta testuetako zenbait iturri hartuta, Sarasolaren galbahea igaro ez duten hitzak ere bildu eta aztertu ditugu (ikus 4.1.5. atala). Eta azkenik, corpusean jaso beharreko hitzak mugatzen izan dugun zailtasuna aipatuko dugu. Hau da, ikerlan honetan «hitza» diogunean zertaz ari garen definitu behar izan dugu, corpusean biltzen diren hitzen arabera, emaitzak asko alda baitaitezke. Eta, inguruko hizkuntzetako lan lexikologikoei jarraituz, oro har, gure corpusean jaso ditugun hitzak esanahia duten unitate lexiko txikienak izan dira, hots, lexemak (3.1.2. atala).

Hirugarrenik, analisitik bertatik sortutako zalantzak eta arazoak azaldu behar ditugu. Zailtasun handienetako bat hitzak zein motatakoak diren zehazteko garaian izan dugu. Eta, zehaztapen hori egiteko hainbat irizpide finkatu behar izan dugu. Euskal ondare zaharreko soilei dagokienean, talde honetan bildu dira XV-XVI. mendeko hiztunek bakuntzat joko zituztela uste ditugun hitzak (ikus 4.1.3.1. atala). Baina, zenbaitetan ez da erraza uste hori ziurtatzea. Ondare zaharreko hitz soil hauek sakon aztertuaz agian deribazio fase desberdinen mugak finkatzen hasteko aukera egon liteke. Eratorriez den bezainbatean, batzuetan argiegia ez den atzizkien eta hitz lokabeen arteko muga marraztu behar izan dugu. Eta, oro har, hitz lokabetzat jo ditugu XV-XVI. mendeetan hitz beregain gisa bizirik zirautenak (ikus 4.1.3.2. atala). Konposatuen artean ere, analisiaren aurkezpenean bertan (4.1.3.3. atala) azaldu dugun legez, arazo nabariak izan ditugu sailkapen egoki bat egiteko. Azkenean Euskaltzaindiaren egungo sailkapena oinarri hartu badugu ere, beharbada, morfologialarien laguntzaz posible da garai hartako konposaketa hobeto islatuko lukeen bestelakorik garatzea. Maileguei dagokienean ere, zalantza nahikotxo izan ditugu, bai hitz batzuk mailegutzat jotzeko, eta bai mailegu direla jakinda euren jatorri zehatza finkatzeko 
(ikus 4.1.4. atala). Arazo hau oso lotuta dago arlo horretan daukagun lanabes faltarekin, ez baita hiztegi etimologiko zabalik.

Analisian aurkitutako arazo metodologikoekin bukatzeko, zenbaitetan datuak interpretatzeko garaian izandako zailtasuna aipatu behar dugu. Ahalegindu gara analisiko emaitzetatik atera beharreko ondorioak autore bakoitzaren hitz bolumena kontuan hartuta erlatibizatuz egiten. Baina, analisitik ateratako zifra edo kopuruen adierazgarritasuna zehaztea ez da beti erraza. Hau horrela, zifren interpretazio egokia lortzeko, estatistikaren lan-metodoa gureganatzea interesgarria izan liteke.

Arazo edo zailtasun hauekin guztiekin ere, ikerketa honek, gure iritziz, bere xumetasunean ekarpen garrantzitsua egin diezaioke euskal lexikoaren historiari. Izan ere, arazo metodologiko horiek identifikatzea bera aurrerapausotzat dugu horren gutxi urratu den euskal lexikologiaren ikerbidean. Gainera, ikerlan honek, corpusa mugatua izanik ere, XV-XVI. mendeetako euskal lexikoaren nolakotasunaren zantzu batzuk ematen ditu. Eta, baita lexikoaren nolakotasun horretan eragin lezaketen faktore batzuk erakutsi ere.

Beraz, jarraian, hitzen analisitik atera ditugun ondorio nabarmenenak azaltzeari ekingo diogu, orokorrenetatik hasi eta zehatzagoetara joaz. Hasteko, gure ikerketan euskal ondare zaharreko hitzak nagusi direla ikusi dugu (ikus 4.1.1. atala). Hain zuzen ere, Euskara Arkaikoko testuetan erabiltzen diren hamar hitzetik ia sei (678, \%58), euskal ondare zaharretik sortuak dira. Bertan, obra handien artean, Oihenart (\%72) eta bereziki RSko (\%78) ugaritasuna da nabarmentzekoena. Baina, Leizarraga (\%57) eta Lazarraga (\%49) kenduta, gainerako guztiek ere batazbesteko orokorretik (\%58) gora dutela antzeman dugu.

Euskal ondare zaharreko hitzen artean, bakunak dira oso nabarmen nagusi (430, \%37). Hitz mota honen erabileran (ikus 4.1.3.1.), RSren ugaritasuna $(128, \% 66)$ da esanguratsuena. Baina, Leizarragak bere handitasunean duen kopuru txikia ere $(275, \% 37)$ nabarmendu daiteke. Izan ere, Leizarraga kenduta, gainerako guztiek \%43tik gora dute horrelakoetan eta, ondorioz, Beraskoitzekoaren testuaren bolumen handiak emaitza orokorra guztiz baldintzatzen duela esan daiteke, hitz bakunen bere ehunekoa emaitza orokorretako ehuneko bihurtuz. Bestalde, hitz soil hauen silaba kopuruaren azterketaren gainean, hamar hitzetik zortzi baino gehiago bi (\%46) edo hiru silabakoak (\%38) direla ikusi dugu. Hiru silabakoen artean, RSk (42, \%33) Etxepare (20, \%20) eta Lazarraga $(35, \% 28)$ alde handi samarrarekin gainditu eta, ia Oihenarten kopurura $(43, \% 26)$ iristea iruditu zaigu azpimarragarriena.

Euskal ondare zaharreko hitz eratorriak askozaz gutxiago (157, \%13) direla erakutsi dugu (ikus 4.1.3.2.). Hitz eratorrien artean ageri diren 39 eratorpen hizkietarik 28 euskal ondare zaharrekoak dira eta 11 mailegatuak. Eratorpen-atzizki erabilienak (-(z) $k o$ alde batera utzita) $-k i_{1}(19$ [6]), -tasun (16 [3]), -tzaile (16 [12]), eta -zio [12] dira. Emaitza hauek hizkien erabilera aztertu duten beste ikerlanetakoekin (Sarasola 1997, Oyharçabal 1996) alderatu ditugu eta, oro har, emaitzak nahiko bat datozela ondorioztatu dugu. Gainera, eratorpen hizki hauek oinarrian hartzen duten horren nolakotasuna ere analizatu dugu eta, batetik, hizki mailegatuek (61) oinarri mailegatuak (56) hartzeko joera handia dutela eta, bestetik, ondare zaharreko hizkietarik (153) zenbaitek eratorpena maileguetara ere (43) zabaldu dutela antzeman dugu. Bestalde, eratorpen hizki hauen artean, lehian egon daitezkeen hainbat behatu ditugu; besteak beste, -os(o) eta -tsu, -tate eta -tasun, -tzaile eta -le, -gile eta -gin, - $k i_{1}$ 
eta -ro, -mendu eta -men, -kunde eta -kuntza. Eta azkenik, hitz eratorriak autoreka aztertu dira eta, bertan, Leizarragaren ugaritasuna (\%14) eta Lazarragaren urritasuna (\%2) dira atera ditugun emaitza adierazgarrienak. Beraskoitzekoaren eratorrien erabilera naroa testu motarekin lotuta egon daitekeela ondorioztatu dugu, hizkuntza guztietan delako erlazio estu bat idazkera jasoaren eta hitz eratorrien ugaritasunaren artean. Eta, Leizarragaren Testamentu Berria moduko testuek ezinbestean behar dute idazkera jasoa eta, ondorioz, hitz konplexuen erabilera.

Kopuru txikiena duen ondare zaharreko taldea konposatuena (91, \%8) da (ikus 4.1.3.3. atala). Bertan, egin dugun sailkapenaren arabera, gehienak mugakizun bereziko Eguzki-lore moduko mendekotasunezkoak dira (33). Eta hurrengo talderik kopurutsuenak lotsagabe, lofalta modukoak (10) eta justaposiziozkoak dira (10). Gainerako motek, ostera, nahikoa hitz gutxi dute. Autorekako analisian, Lazarraga (\%4) eta $R S$ ko (\%4) konposatuen urritasuna eta Isastiren ugaritasuna (\%14) nabarmendu ditugu. $R S$ ko urritasuna bere arkaikotasunarekin lotu daiteke beharbada. Hain zuzen ere, ugari dituen ondare zaharreko hitz soilak sakon aztertuta, posible da bertan konposatu zaharrak aurkitzea. Eta, beraz, testu arkaiko honetan konposatu modernoen sorrera lekarkeen deribazio fase berria hasteke eta, lehenengoa amaitzear zeudela ondorioztatu liteke, agian. Edonola ere, esan bezala, hori baieztatu ahal izateko azterketa ugari egin beharra dago oraindik.

Maileguetara jauzi eginda, euskarak ondoko hizkuntzetatik hartutako berbak gure corpusean 477 (\%41) dira (ikus 4.1.4. atala). Eta bertan, testu handienen artean, Lazarragaren (\%50) ugaritasuna eta, Oihenarten (\%27) eta $R S$ ren urritasuna (\%19) aipatu ditugu. Testu txikien artean, Zumarragak ere (\%19) oso gutxi dituela erakutsi dugu. Emaitza hauek ikusita, badirudi badela zelanbaiteko lotura bat testu generoaren eta maileguen erabileraren artean. Izan ere, errefrauetan mailegu gutxi ageri den bitartean, gainerakoetan ugari (Etxepare \%41, Leizarraga \%42 eta bereziki Lazarragarenean \%50) dira. Emaitza hauek nahikoa bat datoz Etchebarneren (2006) ondorioekin. Hain zuzen, obra literarioetan (\%29-\%41) eguneroko hizkuntzan (\%13-\%23) baino mailegu gehiago erabiltzen dela esaten du eta, gure corpusean ere, eguneroko hizkuntza horretatik hurbil dauden errefrauetan zein Zumarragaren gutunean maileguak literatur obretan baino gutxiago dira. Hitz mailegatuen jatorria aztertuaz, hauetarik gehienak (\%37) hizkuntza erromantzeetatik datozela ikusi dugu. Hala ere, latinetikakoak (\%22) eta aitzinerromantzetik datozenak (\%17) batuta (\%39), mailegu modernoak baino gehiago dira. Guztiarekin ere, analisian azaldu dugun legez, zalantzazkoen kopurua (\%23) altuegia da baieztapen sendorik egin ahal izateko. Maileguen eremu semantikoa aztertzean (ikus 4.1.4.1. atala), corpuseko testu motak kontuan hartuta espero izatekoa zen bezala, kontzeptu abstraktuak (\%22) eta elizarekin lotutakoak (\%12) aurkitu ditugu ugari, baina, tresneria eta materialen alorra ere (\%14) oso joria da. Beraz, kultura erromatarrak euskarari tresneria, material, eta teknika berrien gaineko lexikoan egindako ekarpena ere azpimarratu dugu.

Behin analisi osoko datuak aztertuta, antzeman dugu Leizarragaren testuaren bolumen izugarriak ${ }^{26}$ emaitza orokorrak (ondare zaharreko bakunak \%37, eratorriak (\%27).

26 Leizarragak corpuseko 1170 hitzetatik 752 (\%64) erabiltzen ditu; bigarrenak, Oihenartek, 314 
$\% 13$, konposatuak \%8, maileguak \%41) guztiz baldintzatzen dituela eta ia ez duela uzten gainerako autoreek emaitza horietan eragitea. Horren erakusle dira ia datu orokorren berdinak diren bere ehunekoak: bakunak \%37, eratorriak \%14, konposatuak \%7, maileguak \%42. Hau horrela, interesgarria iruditu zaigu Euskara Arkaikoaren lexikoa Leizarragarekin eta Leizarraga gabe zenbat aldatzen den behatzea (ikus 4.1.1.). Eta, Leizarraga gabe Euskara Arkaikoak mailegu, konposatu eta bereziki eratorri gutxiago eta hitz bakun gehiago izango lituzkeela ikusi dugu.

Euskal Hiztegia oinarri hartuaz egindako analisi honen ondoren, testuetako lexikoaren benetako izaera hobeto ezagutu nahian, Sarasolak bere hiztegitik kanpo utzitako hitzak ${ }^{27}$ jaso eta aztertu ditugu (ikus 4.1.5). Eta, baita emaitza interesgarri samarrak lortu ere. Euskal Hiztegian ageri ez diren hitz kopuru esanguratsua daukatenak $R S$ (20), Oihenart (16), Lazarraga (41) eta batez ere Leizarraga (151) dira. Lehenengo hiruren hitz hauen nolakotasunak ez du orain arte geneukan euren argazkia ia ezer aldatzen, $R S$ eta Oihenarten kasuan ondare zaharrekoak eta Lazarragaren kasuan maileguak baitira gehienak. Baina, Leizarragaren hitz hauek —maileguak gehienak-, Euskal Hiztegia oinarri duten hitz kopuruei gehituz gero nahikotxo aldatzen dira goiko emaitzak. Hain zuzen ere, Leizarragareneko euskal ondare zaharrekoak \%57tik \%54ra igarotzen dira eta, mailegatuak, berriz, \%42tik \%45era. Eta, Leizarragaren hitz hauek, nola ez, bete betean baldintzatzen dituzte datu orokorrak ere: ondare zaharrekoak \%58 izatetik \%55era igarotzen dira eta, maileguak \%41etik $\% 44 \mathrm{ra}{ }^{28}$ Beraz, murriztu egiten da ondare zaharreko hitzen eta maileguen arteko aldea. Aldaketa honek, hiztegiak lagungarri izan badaitezke ere, komenigarriena hitzak testuak zuzenean hustuz biltzea dela gogorarazten digu.

Ondorioen atal honekin bukatzeko, hasieratik bertatik etorkizunerako ikerketa zenbaiten entsegu edo hastapen gisara definitu dugun saio honek hainbat ikerlerro zabaldu ditzake:

1. Batetik, lan lexikologiko batean aurki daitezkeen metodologia arazo zenbait behin zehaztuta, lan metodoa hobeto landu eta fintzeko aukera dago, batez ere corpusa zabalduaz, sailkapenetan eta bestelakoetan zertzelada gehiago egin behar eta ahalko baikenuke.

2. Bestetik, emaitzak esanguratsuagoak eskuratzeko, «A» eta «B» letretara mugatutako corpusa "Z» letraraino zabaltzea oso interesgarria litzateke, lau bider handiago eta sendoago eginaz gure oinarriak. Jakina, sarritan aipatu legez, testuen lexikoaren izaera benetan ezagutzeko, hitz hauen guztien bilketa testuak zuzenean hustuz egitea ezinbestekoa da.

3. Hirugarrenik, hemen jaso ez diren Xv-xvI. mendeetako testuetako lexikoa (eta Landucci bezalako hiztegietakoa) aztertzea ondo legoke, horrela Euskara Arkaikoa hobeto ezagutzeko aukera genuke-eta, baina, ahaztu gabe iturri berriok —bereziki Landuccik — arazo erantsiak dakartzatela beraiekin (gorago aipatu iturriarekiko menpekotasuna, demagun).

\footnotetext{
27 Lazarragaren kasuan, bere eskuizkribua Euskal Hiztegia $(E H)$ osatu ostean aurkitutakoa denez, EHtik kanpo utzitakoaz baino, bertan ageri ez diren hitzez ari gara.

${ }^{28}$ Emaitza hauek Landucciren mailegu ugaritasuna gogorarazi dezakete, nahiz eta ugaritasun hori «estrukturala» izan, iturriari dagokiona, Urgellen (2013) ikerketen arabera.
} 
4. Laugarrenik, eremu semantikoaren azterketa hitz mailegatuetatik konposatu, eratorri eta are bakunetara zabaldu beharra dago, alderaketak egitea ahalbidetuko lukeelako eta, orain arte datu zehatzak baliatuz egin ez diren gogoetak egin bide litezkeelako.

5. Bosgarrenik, bariazio dialektalak lexikoaren nolakotasunean izan lezakeen eraginaren inguruan, gure azterketan nabarmentzeko ezer aurkitu ez dugun arren, azterketa sakonago bat egin ahalko litzateke. Esaterako, De Rijkek (1995) badu gai honetaz ohar interesgarririk -ki, -ro eta gainerako adizlagun modaletako atzizkiak aztertzerakoan. Seguru aski, orokortasun gehiago eta fidagarriagoak sortuko lirateke alderdi honetatik ere datu kopurua lau bider handiagoa eginaz.

6. Azkenik, bidearen bukaeran, ikerlan honek erkagai izan nahiko luke aurreko zein osteko garaietako lexikoaren ikerlanekin. Helburu hori du, adibidez, abiatzear den Euskara Arkaikoa eta Euskara Zaharra besarkatuko dituen gure tesi egitasmoak. Halaber, ez dugu ahantzi nahi corpus osatu eta berrikusi horrek morfologia diakronikorako edo are fonologia diakronikorako izan lezakeen ekarpena, hemen bakuntzat jo diren hitzak egitura horretara iristeko egindako bidea edota sarreren fonotaktika begiratuaz.

7. Akaburako utzi dugu gure saio honekin hastean burutan ez genuen emaitza: euskara batuaren hiztegiaren historia baterako informazio apur bat atera dela uste dugu. Hain zuzen, Sarasolak EHan sartu dituen zein kanpoan utzi dituen hitzen kopuru eta nolakotasunaren nondik-norako zenbait aurkitu ditugu, eta, hemen ezinezko ziren zenbait ikerketatarako bidea eman lezakete. Orobat, Larramendiren hiztegia edo Azkuerena aztertuaz Euskara Arkaikoaren iraupenean edo berrerabileraren ezagutzan sakondu ahalko genuke.

\section{Bibliografia}

Agud, M. \& A. Tovar, 1988-1995, Materiales para un Diccionario Etimológico de la Lengua Vasca. ASJUren gehigarriak, Donostia, 7 liburu (A-orloi).

Akesolo, L., 1982, "Amaseigarren mendeko euskerazko Miserere bat», Karmel 166: 37-47.

Altuna, P., 1979, Etxepareren hiztegia. Lexicón dechepariano. Mensajero, Bilbo.

Arbelaitz, J. J., 1978, Las etimologías vascas en la obra de Luis Michelena. Kardaberatz, Tolosa.

Aresti, G., 1973, «Léxico empleado por Leizarraga de Briscous», FLV 13: 61-128.

Arzamendi, J. \& M. Azkarate, 1983, "Léxico de los refranes de B. de Zalgiz», ASJU 17: 265-327.

Azkarate, M., 1990, Hitz elkartuak euskaraz. Mundaiz, Donostia.

—, 1992, «Oihenarten lexiko sorkuntza», in Oihenarten laugarren mendeurrena, Iker-8, Euskaltzaindia, Bilbo.

— \& E. Perez Gaztelu, 2014, Hitz elkarteak/2. Euskaltzaindia, Bilbo.

Barber, C., 1997 (1976), Early Modern English. Edinburgh University Press, Edinburgh.

Bilbao, G. et al., 2010, Lazarraga eskuizkribua: konkordantzia (1.0) [PDF], Vitoria-Gasteiz: UPV/EHU. Interneten eskuragarri: <http://www.lazarraga.com> [Kontsulta: 2014/05/01].

Bueno, A., 2006, «Atzizkiak aztergai autore ezberdinen begiradapean», ASJU 50: 221-244. 
Dworkin, S., 2012, A History of the Spanish Lexicon, a Linguistic Perspective. Oxford University Press, New York.

Etchebarne, M., 2006, «L'emprunt lexicale d'origine latino-romance en basque: une approche lexico-statistique». Artxiker.

Etxenike, M. T., 1987, Historia lingüistica vasco-románica. Paraninfo, Madril.

—, 1997, Estudios lingüisticos vasco-románicos. Istmo, Madril.

Euskaltzaindia, 2002 (1993), Euskal Gramatika Laburra: Perpaus Bakuna, Bilbo: Euskaltzaindia.

Gómez, R., 2011, "Presencia e influencia del castellano en el manuscrito Lazarraga», Oihenart 26: 231-258.

Görlach, M., 1991, Introduction to Early Modern English. Cambridge University Press, Cambridge.

Lafitte, P., 1979, Grammaire basque: (navarro-labourdin littéraire). Elkar, Donostia.

Lakarra, J. A., 1981, «Betolatzaren hiztegia», ASJU 15: 235-272.

—, 1984, Euskal thesauruserako gaiak: hegoaldeko testuak (1700-1745). UPV/EHUko tesina, Vitoria-Gasteiz.

—, 1993, XVIII. mendeko hiztegigintzaren etorkiez. UPV/EHUko tesia, Vitoria-Gasteiz.

—, 1995: "Reconstructing the root in Pre-Proto-Basque» in Hualde, Lakarra \& Trask (arg.), Towards a history of the Basque language, 189-206. Amsterdam: Benjamins.

—, 1996a, Refranes y Sentencias: ikerketak eta edizioa. Euskaltzaindia-Bizkaiko Diputazioa, Bilbo.

—, 1996b, «Lexiko berrikuntza euskal hiztegi zaharretan: zenbait ikergai», Uztaro 19: 3-40.

—, 1997, «Euskararen historia eta filologia: arazo zahar, bide berri», ASJU 31-2: 447-535.

—, 2009, «Forma canónica y cambios en la forma canónica en la prehistoria de la lengua vasca», Palaeohispanica 9: 557-609.

—, 2010, "Refranes y Sentencias-en lexikoaz ohar dozena». In S. Gómez Seibane \& J. L. Ramírez Luengo (arg.), Maestra en mucho. Estudios filológicos en homenaje a Carmen Isasi Martínez, 159-179. Voces del Sur, Buenos Aires.

—, 2012, "Mailegaketa eta berreraiketa euskararen historiaurrearen ikerketan», in I. Igartua (arg.), Euskara eta inguruko hizkuntzak historian zehar, 17-64. Eusko Jaurlaritza, Vitoria-Gasteiz.

— \& C. Mounole, 2014, "Euskara Arkaikoa (1400-1600)» in J. Gorrochategui, I. Igartua \& J. A. Lakarra (arg.), Euskararen Historia. Eusko Jaurlaritza, Gasteiz.

Mitxelena, K., 1958, «Introducción» [a Landuchio] in Agud \& Michelena (arg.), N. Landuchio. Dictionarium Linguae cantabricae (1562). Donostia: Gipuzkoako Foru Aldundia.

-, 1960, Historia de la literatura vasca. Minotauro, Madril.

—, 1961, «Euskal iztegigilleak XvII-XvIIIgarren mendeetan», Euskera 6: 7-22.

—, 1963, Lenguas y protolenguas. Salamanca, Berrarg, ASJU-ren Gehigarriak 1990.

-, 1964, Textos arcaicos vascos. Minotauro, Madril.

—, 1970, Estudio sobre las fuentes del Diccionario de Azkue. Centro de Estudios Históricos de Vizcaya, Bilbo.

—, 1974, «El elemento latino-románico en la lengua vasca». Berrarg., Palabras y Textos: 195-219.

—, 1977, Fonética Histórica Vasca. 2. argitalpen osotua, Gipuzkoako Foru Aldundia, Donostia.

— \& I. Sarasola, 1987-2005, Orotariko Euskal Hiztegia. Euskaltzaindia, Bilbo. 
Mujika, L. M., 1978, Origen y desarrollo de la sufijación euskerica. EV argitaletxea, Donostia.

—, 1982, Latina eta erromantzearen eragina euskaran. Sendoa, Donostia.

Nevalainen, T., 1999, "Early Modern English lexis and semantics», in J. Lass (arg.), The Cambridge history of the English language III 1476-1776, 332-459. Cambridge University Press.

Orpustan, J.-B., 1992 (arg.), Arnaud d'Oihénart. Proverbes et poesies basques (1657- 1664). Izpegi, Baigorri.

Oyharçabal, B., 1996, «Hitz eratorriak Materreren Dotrina christiana delakoan (1617)», Lapurdum 1: 37-71.

Peillen, T., 1996, "Jakes Belakoaren erran zaharrak eta filosofia», Euskera XL1 (2): 769-789.

Quemada, B., 1967-, Les dictionnaires du français moderne, 1539-1863. Didier, Paris.

De Rijk, R., 1995, «Basque manner adverbs and their genesis», ASJU 39-I: 53-82.

Rohlfs, G., 1933, «La influencia latina en la lengua y la cultura vascas», RIEV 24: 323-348.

Salaberri Muñoa, P., 2002, Iraupena eta lekukotasuna, Euskal Literatura idatzia 1900 arte. Elkar, Donostia.

—, 2010, «Iturri urdinen bila (Leizarragaren Testamentu Berria eta hari erantsitakoak)». Egan 1-2: 109-149.

Sarasola, I., 1980, Materiales para un thesaurus de la lengua vasca. Tesi argitaragabea.

—, 1986, "Larramendiren eraginaz eta», ASJU 20-1: 203-215.

—, 1997, «Euskal hitz altxorraz». ASJU 31-2: 617-642.

—, 2007 (1996), Euskal Hiztegia. Elkar, Donostia.

Segura, S. \& J. M. Etxebarria, 2001, Del latín al euskara. Latinetik euskarara. Deustuko Unibertsitatea, Bilbo.

Soto-Mitxelena, K., 1978-79, "El lexicón de Refranes y Sentencias de 1596», ASJU 12-13: 15-86.

Tovar A., Otte E. \& Mitxelena K., 1980, «Nuevo y más extenso texto arcaico vasco: de una carta del primer obispo de México, fray Juan de Zumarraga», Euskera 26-1: 5-14.

Trask, R. L., 1997, The history of Basque. Londres, Routledge.

Ulibarri, K., 2013, «External History. Sources for historical research», in M. Martinez Areta (arg.), Basque and Proto-Basque, 89-117. Peter Lang. Frankfurt am Main, Berlin, Bern, Bruxelles, New York, Oxford, Wien.

Urgell, B., 1997, «Estudios en torno a la historia de la lexicografía vasca», ASJU 31-2: 643-685.

—, 2000, Larramendiren Hiztegi Hirukoitzaren osagaiez. UPV/EHUko tesia, Vitoria-Gasteiz.

—, 2002, Euskal Lexikografia ikasgairako Memoria, Gasteiz.

—, 2013, «Landucciren hiztegien ordena eta honen eragina euskarazko hiztegian», in R. Gómez \& M. J. Ezeizabarrena (arg.), Eridenen du zerzaz kontenta. Sailkideen omenaldia Henrike Knörr irakasleari (1947-2008). UPV/EHU, Bilbo.

Vendler, Z., 1967, "Verbs and Times», Linguistics and Philosophy. Ithaca / New York: Cornell University Press, 97-121.

Villasante, L., 1973, Palabras vascas compuestas y derivadas. Editorial Franciscana de Aránzazu, Ońati.

—, 1974, Axular-en hiztegia. Editorial Franciscana de Aránzazu, Oñati.

Zalbide, M., 1992, Hitz-elkarketal 4, hitz elkartuen osaera eta idazkera. Euskaltzaindia, Bilbo. 
Zawiszewski, A., 2001, «Vocabulario básico y préstamos en vascuence vizcaíno y otras lenguas, ASJU 35-2: 789-891.

Zuazo, K., 2012, Arabako euskara. Elkar, Donostia.

Zubiaur, J. R. \& J. Arzamendi, 1976, «El léxico vasco de los refranes de Garibay», ASJU 101: $47-144$.

Zuloaga, E., 2011, «Bizkaiko jauntxoen inguruko herri literaturaz: Plentziako 1603ko hiru esaera zahar eta Refranes y Sentenciasen jatorria, eta proposamen bat Arrasateko erreketaren kantuez», ASJU 45-2: 53-69.

Endika Blanco Brabo

HEIS, Micaela Portilla Ikergunea,

Nieves Cano 27, 01006 Gasteiz

endibrabo@hotmail.com 